NUREG/CR-5280

BNL-NUREG-52178

Vol. 1

\title{
Age-Related Degradation of Westinghouse 480-Volt Circuit Breakers
}

Aging Assessment and Recommendations for Improving Breaker Reliability

Prepared by M. Subudhi, W. Shier, E. MacDougall

Brookhaven National Laboratory

Prepared for

U.S. Nuclear Regulatory Commission

\section{Received by OSTI \\ JUL 271990}




\section{AVAILABILITY NOTICE}

\section{Availability of Poference Materials Cited in NRC Publications}

Most documents cited in NRC publications will be avallable from one of the following sources:

1. The NRC Public Document Room, 2120 L. Street, NW. Lower Level. Washington, DC 20555

2. The Supertintendent of Documents. U.S. Government Printing Office. P.O. Box 37082, Washington, DC $20013-7082$

3. The National Technical intormation Service, Springheld, VA 22161

Alhough the listing that follows represents the malonty of documents clted in NRC publications, 雊 Is not intended to be exhaustive.

Referenced documenis avallable for inspection and copylng for a toe from the NRC Public Document Room inciude NRC correspondence and internal NRC memoranda; MRC Offlce of inspection and Enforcement bulletins, chrculars, Information notices, Inspection and Investigation notlces; Licensee Event Reports; vendor reports and correspondence; Commisston papers; and applicant and licenseo documents and correspondence.

The following documents in the NUREG serles are avallable for purchase from the GPO \$ales Program: formal NPC staff and contractor reports. NRC-sponsored conterence proceedings, and NRC bookets and brochures. Also avaliable are Regulatory Guides, NRC regulattons in the Code of Federal Regulations, and Nuclear Regulaton Commission issuances.

Documents avallable from the National Technical information Service include NuREC serles reports and technical reports prepared by other tederal agencles and reponts prepared by the Atomic Energy Commission, forerunner agency to the Nuolear Requlatory Commission.

Documents avaltabie from public and special technical ibrarles Include all open fiterature ttems, such as books. Journal and periodical articies, and transactions. Federal Register notices, tederal and state legislation, and congresslonal reports can usually be obtahed from these libraries.

Documenis such theses, dissertations, forelgn reports and transtations, and non-NRC conterenco proceedings are avallable for purchase from the organzation sponsorting the publication clted.

Single coples of NPC dratt reports are avaliable troe, to the extent of supply, upon wrthten request to the Ofice of intormation Pesources Management, Distribution Section, U.S. Nuclear Regulatory Commission. Washington. DC 20555.

Coples of Industry codes and standards used in a substantive mamer in the NRC rogulatory process are malntained at the MRC Lbrary, 7920 Norfoll Avenue. Bethesda, Maryland, and are avallable there for reterence use by the public. Codes and standards are ustally copytighted and may be purchased from the originating organtzation or. Whey aro American Natlonal Standards, Fom the American National Standards Instlute, 1430 Broadway, New York, NY 10018.

\section{DISCLAMER NOTICE}

This repon was prepared as an accoun of work sponsored by an agency of the Unied States Govemment. Neither the United States Covemment nor any agency thereof, or any of this employees, makes any warranty, expresed or implied, or assumes any legal hability of responsibitiy for any third party's use, or the results of such use, of any iniormation, apparatus, product or process disclosed in this report, or represents that its use by such third party would not infinge privately owned rights. 


\section{DISCLAIMER}

This report was prepared as an account of work sponsored by an agency of the United States Government. Neither the United States Government nor any agency Thereof, nor any of their employees, makes any warranty, express or implied, or assumes any legal liability or responsibility for the accuracy, completeness, or usefulness of any information, apparatus, product, or process disclosed, or represents that its use would not infringe privately owned rights. Reference herein to any specific commercial product, process, or service by trade name, trademark, manufacturer, or otherwise does not necessarily constitute or imply its endorsement, recommendation, or favoring by the United States Government or any agency thereof. The views and opinions of authors expressed herein do not necessarily state or reflect those of the United States Government or any agency thereof. 


\section{DISCLAIMER}

Portions of this document may be illegible in electronic image products. Images are produced from the best available original document. 


\title{
Age-Related Degradation of Westinghouse 480-Volt Circuit Breakers
}

\author{
Aging Assessment and Recommendations \\ for Improving Breaker Reliability
}

Manuscript Completed: May 1990

Date Published: July 1990

l'repared by

M. Subudhi. W. Shier, E. MacDougall

S. K. Aggarwal, NRC Program Manager

Brookhaven National Laboratory

Upun. NY 11973

\section{Prepared for}

\section{Division of Engineering}

Office of Nuclear Regulatory Research U.S. Nuclear Regulatory Commission Washington, DC 20555

NRC FIN A3270

\begin{abstract}
DISCLAMMER
This report was prepared as an account of work sponsored by an agency of the United States Government. Neither the United States Government nor any agency thereof, nor any of their employees, makes any warranty, express or implied, or assumes any legal liability or responsibility for the accuracy, completeness, or usefulness of any information, apparatus, product, or process disclosed, or represents that its use would not infringe privately owned rights. Reference herein to any specific commercial product, process, or service by trade name, trademark, manufacturer, or otherwise does not necessarily constitute or imply its endorsement, recommendation, or favoring by the United States Government or any agency thereof. The views and opinions of authors expressed herein do not necessarily state or reflect those of the United States Government or any agency thereof.
\end{abstract}


: 
An aging assessment of Westinghouse DS-series low-voltage air circuit breakers was performed as part of the Nuclear Plant Aging Research (NPAR) program. The objectives of this study are to characterize age-related degradation within the breaker assembly and to identify maintenance practices to mitigate their effects. Since this study has been promulgated by the failures of the reactor trip breakers at the McGuire Nuclear station in July 1987, results relating to the welds in the breaker pole lever welds are also discussed.

The design and operation of DS-206 and DS-416 breakers were reviewed. Failure data from various national data bases were analyzed to identify the predominant failure modes, causes, and mechanisms. Additional operating experiences from one nuclear station and two industrial breaker-service companies were obtained to develop aging trends of various subcomponents. The responses of the utilities to the NRC Bulletin 88-01, which discusses the center pole lever welds, were analyzed to assess the final resolution of failures of welds in the reactor trips.

Maintenance recommendations, made by the manufacturer to mitigate agerelated degradation were reviewed, and recommendations for improving the monitoring of age-related degradation are discussed. As described in Volume 2 of this NUREG, the results from a test program to assess degradation in breaker parts through mechanical cycling are also included. The testing has characterized the cracking of center-pole lever welds, identified monitoring techniques to determine aging in breakers, and provided information to augment existing maintenance programs. Recommendations to improve breaker reliability using effective maintenance, testing, and inspection programs are suggested. 


\section{SUMMARY}

An aging assessment of the Westinghouse DS-series low-voltage air circuit breakers (particularly DS-206 and DS-416) was performed. These breakers are used for Class $1 E$ application in nuclear power plants. DS 416 breakers in particular, are used for reactor trip applications. This work was performed under the auspices of the U.S. Nuclear Regulatory Commission (NRC) as part of the Nuclear Plant Aging Research (NPAR) program.

Following the failure of the center-pole lever weld at the McGuire Nuclear Station Unit 2 in July 1987, the NRC issued Bulletin 88-01 (February 1988) to all holders of operating licenses or construction permits for nuclear power plants. This study was started at that time; 1) to identify all failures modes, 2) to assess the effectiveness of the NRC Bulletin requirements, and 3) to recommend activities which would effectively detect and mitigate age-related problems in breakers.

To achieve the above objectives, various data bases were evaluated including Licensee Event Reports (LERs), Nuclear Plant Reliability Data System (NPRDs), In-Plant Reliability Data System (IPRDS), and Nuclear Power Experience (NPE). The failure modes predominant in nuclear power plants were determined by sorting these operating experience data. Corresponding causes and mechanisms of failure were determined as well. Instruction manuals including schematics and manufacturer's maintenance manual were analyzed to understand the effect of material aging during the service life of the breakers. This analysis was further augmented by technical discussions with maintenance and service personnel from the electrical supply industry and with NRC inspectors involved in assessing breaker problems in the nuclear industry.

The findings from this study form a technical basis for understanding the aging effects in DS-series breakers. To formulate an effective maintenance program, a test program was performed at Brookhaven National Laboratory (BNL) which simulated the operating life of breakers in nuclear plants. The results provided additional knowledge on breaker aging, as well as on the kind of monitoring techniques and their frequencies that can predict the condition of the breaker. The conclusions from this study are summarized below:

Reactor Trip Breaker Reliability (NRC Generic Letter 83-28)

- The earliex reactor trip breaker events caused by sticking of problems in the UVTA linkages, associated with both DB-50 (earlier vintage) and DS- 416 breakers seem to have been rectified in recent years after implementing periodic cleaning and lubrication of the UVTA linkages. Adherence to the criteria in NRC Generic Letter 8328 following the Salem ATWS events has also remedied the situation.

- The life of a DS -416 breaker is estimated to be 5000 cycles or 20 years of operating life. Hence, no additional testing in qualifying this equipment is recommended. 
- Several problems were noted in refurbishing the test breaker with spare parts. The new parts exhibited higher aging rate than those that came with the original breaker. Hence, stringent criteria in qualifying spare parts for use in RTBs should be developed.

Center Pole Lever Welds (NRC Bulletin 88-01)

- Both DS-206 and DS-416 breakers are manufactured as conmercial grade components and are then dedicated for class IE application. Based on the responses of the utilities, a large percentage of the inspected breakers did not pass the bulletin criteria (i.e., shortterm and/or long-term inspections).

- Inspection programs have identified the typical causes of substandard welds which are:

- Inadequate size of weld $\left(<3 / 16^{\text {" fillet })}\right.$

- $\quad$ mall weld length $\left(<180^{\circ}\right)$

- multiple passes\% (not a continuous one-pass-per-design requirement) indicating presence of porosity, coldwork between adjacent passes.

- improper fusion between the parent metal and weld metal (existence of cold work, porosity, cleavages)

- poor workmanship

- New pole shafts which replace the older units, and repairs of existing welds, passed the inspection criteria. Replacement and repair appear to have resolved the problems of weld cracking. The BNL test program confirmed these results.

- Many utilities stated that it was difficult to perform the recommended Bulletin inspections without disassembling the breaker.

- Cracking of center pole lever welds that are substandard is directly proportional to the number of breaker cycles. Hence, breakers expected to experience a large number of cycles should undergo more frequent inspections. Based on the test results, \#1 and \#3 welds indicate cracks first, and after they grow to sizes of $25 \%$ of the total weld, misalignment among the pole levers causes other breaker problems.

* Westinghouse allows multiple passes as they do not lead to a bad weld. 
- Aging of structural components and parts of the contact assembly due to mechanical cycling was not evident from the test.

- In addition to the welding problems, a large percentage of breaker failures are attributed to the parts of the power operated mechanism. These include:

- problems of electrical control involving switch contacts, coil burnings, overcurrent trip devices, (e.g., STA, UVTA), loss of contact due to parameter adjustments, and charging motor malfunctions; control coil burnouts are as a result of aging of some other parts in the operating mechanism;

- mechanical wear of ratchet wheel assembly, oscillator, motor crank and handle, closing cam, stop roller, and roller constraining link;

- binding of linkages due to problems in lubrication (excessive/wrong kind of lubricants, or lack of proper lubrication) including main drive link, main roller, and linkage bearings;

- broken springs, $\mathrm{x}$-washers, and pivot pins.

- Based on the test results, the safe life of a Class $1 E$ breaker is estimated to be 5000 cycles or 20 years for both DS-416 and DS-206 models.

- Breakers in systems (such as CVCS, IA) that are subjected to more frequent cycles are susceptible to premature failures. Burning of closing coils and degradations of insulation in the charging motors dominate the failure modes.

- Breaker parts that receive periodic maintenance (i.e., inspection, replacement, or refurbishment) exhibit the least unexpected failures. These parts include main and arcing contact assemblies, and arc chutes.

\section{Improving Breaker Reliability}

- Exchange of technical information relating to the design and operating experience between the utilities and the manufacturer could improve the reliability of breakers.

- A uniform maintenance program, such as that developed by the owner's group for reactor trip breakers ${ }^{13}$, should be developed for all class IE breakers. 
- The weak links in a breaker assembly include bad welds in the \#3 lever of the pole shaft ( 3000 cycles), and the newly procured indicator springs ( 2000 cycles). All other parts, based on this test have a life of over 10,000 cycles.

- Since the design life of a breaker is characterized by the number of cycles ( 4000 for DS-416 and 12,500 for DS-206 suggested by the manufacturer), a cycle counter on each class $1 \mathrm{E}$ breaker is required.

Based on the operating experience review of breaker performance in the nuclear industry and the 1 ife testing at BNL, the following recommendations are likely to improve the overall breaker reliability:

- A cycle counter should be installed on each Class IE breaker to register the actual cycles experienced.

- While procuring a new breaker or spare parts for an existing one, careful attention should be given to assess their design application, and receipt inspection should be made, specifically for the purpose of identifying sizes, shape, and irregularities (i.e., indicator spring hook bends).

- The 1ife of a DS-416 (or DS-206) breaker is estimated to be either 5000 cycles or 20 years, whichever comes first.

- At each surveillance testing interval, and/or at each 3 to 6 month period (or 50 to 100 cycles), the breaker parts vulnerable to aging should be inspected and refurbished if required.

- An annual (or 250 cycles) maintenance schedule should include a complete checkup of all parts, lubrication at recommended locations, and replacement of degraded components. 


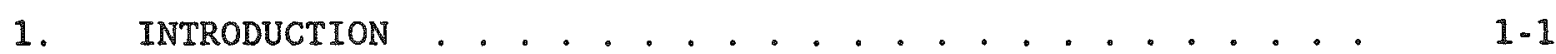

1.1 Background ................. . . . 1 . 1

1.2 Objectives ................ 1-3

1.3 Scope of Work ................ 1-3

2. WESTINGHOUSE DS-SERIES CIRCUIT BREAKERS . . . . . . . . $2-1$

2.1 Design and Construction ............ 2. 2 .

2.1.1 Structural Components ......... 2-3

2.1.2 Mechanical Components ........... 2-4

2.1.3 Electrical and Electronic Components . . . . 2.9

2.1.4 Optional Accessories............ 2.12

2.2 Principles of Breaker Operation........ 2-13

2.2.1 Closing Operation ............. 2-13

2.2.2 Tripping (Opening) Operation....... 2-13

3. UTILITY RESPONSE TO NRC BULLETIN 88-01 . . . . . . . . $3-1$

3.1 Required Inspections and Acceptance Criteria . . . . 3-1

3.1.1 Short-term Inspections........... $3-2$

3.1.2 Long-term Inspections .......... . 3-2

3.2 Results of the Review of Utility Responses . . . . 3-2

3.3 Discussion ................... $3-8$

4. OPERATING EXPERIENCE DATA ANALYSIS ........... $4-1$

4.1 Analysis of Previous Operating History ...... . 4-2

4.2 Analysis of Current Operating History....... $4-3$

4.2.1 Analysis of NPRDS Data.......... . 4.3

4.2.2 Review of Nuclear Power Experience..... . 4.8

4.3 Summary of Results .............. $4-9$

5. INDUSTRIAL EXPERIENCE ............... $5-1$

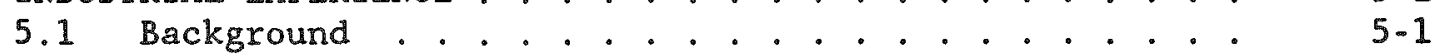

5.2 Salem RTB Failures .............. $5-2$

5.3 Westinghouse Perspectives ............ $5-4$

5.4 Breaker Service Industry (Other Than Westinghouse) . 5-5

5.5 Feedback from Individual Utility ......... 5-9

5.5.1 Pole Shaft Welds ............ 5-9

5.5.2 Other Breaker Problems......... . 5-10

5.6 Discussion ................ 5-12 
6. CURRENT MAINTENANCE PRACTICES AND LIFE TEST RESUlTS . . . $6-1$ 6.1 Breaker Maintenance Recommendations (Westinghouse) $6-1$ 6.1.1 General Practices . . . . . . . . . . 6.1 .2 Specific Activities . . . . . . . . . . $6-1$

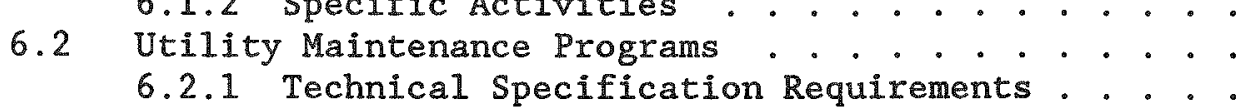
$6-4$

6.3 Life Testing of DS-416 Breaker

6.4 Discussions of a DS-416 Breaker ${ }^{\circ} \cdot \cdot^{\circ} \cdot \cdot^{\circ} \cdot{ }^{\circ} \cdot{ }^{\circ} \cdot$

7. CONCLUSIONS AND RECOMMENDATIONS .............. $7-1$

7.1 Conclusions . . . . . . . . . . . . . . . $7-1$

7.1.1 Aging Assessment . . . . . . . . . . . 7-1

7.1.2 Pole Shaft Weld Failure ......... . 7-2

7.1.3 Programs for Mitigating Aging . . . . . . . 7-3

7.2 Recommendations ............... . . $7-4$

7.2.1 NRC Generic Letter 83-28 on RTBs . . . . . . 7-4

7.2.2 NRC Bulletin 88-01 on Pole Shaft Welds... 7-5

7.2.3 Improving Breaker Reliability . . . . . . $7-6$

8. REFERENCES ....................... $8-1$

APPENDIX A ...................... . . . A 1 
Figure 2.1

Figure 2.2

Figure 2.3

Figure 2.4

Figure 2.5

Figure 2.6

Figure 2.7

Figure 2.8

Figure 3.1

Figure 4.1

Figure 4.2

Figure 4.3

Figure 4.4

Figure 4.5

Figure 5.1
Functional Single Line Diagram of a Typical DS-416

Reactor Trip Switchgear Assembly

DS-416 Breakers (the DS-206 is similar) . . . . $2-4$

Structural Components of a Switchgear Assembly . 2-5

Type DS-206/DS-416 Breaker Position in a

Switchgear Assemply . . . . . . . . . 2-6

Operating mechanisms ........... 2-8

Arrangement of the Principal Parts of a Completely Power Operated Mechanism (the close spring is shown in the charged position) ........ 2-10

Type DS206 Pole Unit Assembly - Front View . . 2-11

Schematic illustration of Tripping System . . . 2-11

Pole Shaft Assembly .............. 3-1

DS Breaker Failure Modes - NPRDS . . . . . . 4-4

Failure Cause.............. 4.5

DS Failures with Age ........... 4-7

Systems Affected ............. 4-7

Systems Operating Status When DS Breaker Failure

Occurred .............. . 4-8

Pole Shaft with levers . . . . . . . . . 5-6

(a) Stop Lever (Left) Weld ......... . 5-6

(b) Left Pole Lever Weld . . . . . . . . 5-6

(c1) Center Pole Lever Weld . . . . . . . . 5-7

(c2) Center Pole Lever Weld . . . . . . . . 5-7

(d) Anti-bounce Lever Weld . . . . . . . 5-7

(e) Auxiliary Switch Drive Link Lever Weld. . . 5-8

(f) Right Pole Lever Weld . . . . . . . . . 5-8

(g) Stop lever (Right) Weld ........ 5-8 
FIGURES (Cont'd)

Page

Figure 5.2 Maintenance History for Four Charging Pump-Motor Breakers . . . . . . . . . . . . 5-11

Figure 6.1 Contacts and Their Adjustment, DS-206 Breaker . . 6-6

Figure 6.2 Contacts and Their Adjustment, DS-416 Breaker . 6-7

Figure 6.3 Breaker With Barrier Removed to Show Mounting

of Arc Chutes . . . . . . . . . . . 6-8

Figure 6.4 DS-206 Arc Chute with Details......... 6-8

Figure 6.5 DS-416 Arc Chute with Details......... 6-8 


\section{TABLES}

Page

Table 3.1

Short-term Inspection Criteria ....... . 3-3

Table 3.2

Long-term Inspection Criteria........ . 3-3

Table 3.3

Plants Reported Having No DS-Series Breakers

in Class 1E Applications .......... 3-4

Table 3.4 Responses of utilities with DS Breakers

a) Short Term Inspection Results . . . . . . 3-6

b) Long Term Inspection Results . . . . . . . 3-7

Table 4.1

DS Circuit Breaker Failures . . . . . . . 4-2

Table 4.2

DS Breaker Subcomponent Failures - NPRDS . . . 4-3

Table 4.3

Summary of Failure Causes for Circuit Breakers . $4-6$

Table 6.1

Minimum Dimensions for Contact Adjustments . . . 6.5 


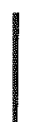

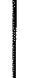




\section{ACKNOWLEDGEMENTS}

The authors wish to thank the NRC Program Manager, Satish R. Aggarwal for his comments and guidance on various phases of this work. We also appreciate cooperation from various utilities, breaker vendors, and Westinghouse in providing valuable information. Our special thanks go to Darl Hood of NRC for his assistance in collecting the utilities' responses to the NRC Bulletin.

We would also like to express our gratitude to various members of the Engineering Technology Division of BNL including Robert E. Hall, John H. Taylor, and William Gunther for their technical assistance, guidance, and reviewing of this report.

We also wish to thank Ann Fort for her help in preparing this manuscript. 


\section{INTRODUCTION}

Metal-enclosed switchgear with DS series drawout air circuit breakers are manufactured by Westinghouse Electric Company. They are used to control and protect power circuits up to 600 volts. Although the switchgear assembly is composed of units designed for a specific application, each unit is normally divided into three or four compartments containing the DS type air circuit breakers. An instrument compartment may also be included to contain other devices such as potential transformers, instruments, meters, relays, and secondary control devices. The back of the unit includes bus bars and space for the main cables, and their connections.

Among all of the safety applications of these breakers, one of the most important functions is to supply electric power to the control cabinets of a Pressurized Water Reactor (PWR) for the reactor control rods. One of the safety related functions of the equipment is to interrupt the power from the rod drive motor-generator set to the rod control cabinet on command from a reactor trip signal. The command can originate automatically from the solid state reactor protection system, or manually from the main control board or locally at the reactor trip switchgear. Interruption of the power to the rod control cabinet causes the control rods to fall by gravity into the reactor core for a PWR, thereby causing the reactor to shutdown. Similar types of breakers are also manufactured by the General Electric Company are typically used in some nuclear plants. A third manufacturer of this type of circuit breaker is the Brown Boveri Electric Company.

Two Westinghouse circuit breakers typically used in recent years in the safety systems of a nuclear power plant are the DS-206 and DS-416 models. They are both low-voltage units with ratings of 240,480 , and 600 volts. The construction, internal components, and mechanisms are similar except that the maximum continuous current ratings are different. The DS-416 has a top range of 1600 amperes, compared to 800 amperes for the DS-206. Also, the number of fingers in the main disconnect contacts vary: the DS-206 has two moving blades, whereas, the DS-416 has four moving blades. The sizes of other subcomponents vary between the two models depending on their current ratings.

\subsection{Background}

Problems associated with both molded-case and metal-clad circuit breakers used in nuclear power plants are evident from the issuance of numerous NRC information notices, bulletins, and generic letters during the last decade (see Appendix A). These failures have been caused by the malfunction of subcomponents, inadequate periodic tests and maintenance, manufacturing deficiencies, age-related problems, refurbishment with "bogus" units, and coordination problems with protective relays. All of these problems identified by NRC are associated with safety applications in nuclear plants and have generic concerns throughout the industry. 
IE Information Notice No. $85-93$ refers to malfunctions in closing the Westinghouse DS-breakers for Class $1 \mathrm{E}$ application. This malfunction was caused by the broken spring release latch levers. A number of other problems presented in NRC Information Notice No. 87-35 include wedging of the main roller between the raised edges of the close cam and the right-hand side frame plate, uneven wear of the four segments in the cam assembly, distortion of stop roller into a mushroom-like shape due to peening, and improper brazing of the pivot pin to the trip latch. NRC Information Notice No. 87-61 relates to some potential problems caused by the failure of $W-2$ type cell switches, which are sometimes used in the DS-series breaker application. These switches provide signals that the breaker is positioned properly inside the cell. The problems were caused by the loss of spring tension by deforming the spring retainer in the spring return mechanism of the cell switch. Finally, NRC Bulletin No. 88-01 describing the weld failures between the pole shaft and the center pole lever, found that as these breakers age there exist excessive misalignment of the main roller on the close cam, and also insufficient clearance between the breaker's moving parts and the breaker casing.

The high level of attention given to reactor trip circuit breakers relates to their importance in achieving safe shutdown of the reactor. Problems relating to Westinghouse DS-series breakers and the earlier vintage DB-50 breakers were attributed to the electrical control and trip mechanisms ${ }^{1}$. Problems in the electrical control system involved dirty auxiliary switch contacts, coil burnout, the malfunction of overcurrent trip devices, deterioration of undervoltage trip attachment (UVTA), and problems with wiring and sensors. The trip mechanism problems were malfunctions in the latching device, inoperability of the charging motor, and degradation of the charging spring. Most of these problems may be attributed to ineffective maintenance or installation procedures in nuclear power plants. NRC Bulletin 88-01 calls for an effective inspection of 1) the substandard welds on the pole shafts of Westinghouse DS-series breakers, and 2) the alignment in the breaker closing mechanism. This bulletin was issued after the RTB failure at McGuire Unit 2 in July 1987, caused by the lack of fusion (i.e., lack of characteristic weld bead ripple, notches at the edges of the weld beads, and small evidence of base metal melting) during the welding process. This problem was first reported in the NRC Information Notice No. $87-35$.

On July 2, 1987, McGuire Nuclear Station Unit 2 was performing drop tests of the control rod after a refueling outage. The plant was in the hot shutdown mode. With all control rods inserted and the RTBS closed for testing the next bank of control rods, station personnel observed smoke in the vicinity of the RTBS. A manual trip of $A$ and $B$ train RTBs was initiated from the control room. Only the A train RTB opened. The B train RTB was eventually tripped manually at the breaker panel. The smoke had come from the shunt trip coil on the $B$ train breaker, which had burned and shorted during breaker operation. The coil is designed for intermittent duty and to only carry current until the breaker opens. Failure of the breaker to open resulted in a prolonged and damaging current in the coil. 
An NRC Augmented Inspection Team (AIT) evaluated the licensee's investigation into this problem. The broken weld was on the center pole lever of the pole shaft. Except for the shunt trip coil that had burned and shorted while trying to open the breaker, the breaker's electrical controls and auxiliary contacts were verified to be properly wired and operating as designed. The investigation revealed abnormal wear on the breaker mechanism closing coil and a broken weld on the pole shaft. Further investigation was carried out in a Westinghouse Laboratory ${ }^{2}$, and the Franklin Research Center ${ }^{3}$ conducted an independent evaluation of the incident sponsored by the NRC.

Based on these investigations, NRC Bulletin 88-01 was issued on February 5, 1988, to all holders of operating licenses or construction permits for nuclear power reactors. The bulletin described similar occurrences at several other plants using these breakers for reactor trips, and requested implementation of a short-term and a long-term inspection program to determine the magnitude of the safety applications of the DS-series breakers and the effectiveness of the recommended inspection programs.

NRC expressed concern over the implementation of the manufacturer's QA program, lack of knowledge of subcomponent design limits, effectiveness of the recommended inspection programs, adequacy of current maintenance practices, and the awareness of maintenance people on the impact of subcomponent degradation on breaker performance 4 .

\subsection{Objectives}

The objectives of this study are:

- to identify all modes, causes, and mechanisms associated with DSseries breaker failures by evaluating the operating experience on component failures,

- to assess the effectiveness of the recommended inspection program to alleviate the problems of pole weld cracking; this work will include evaluating the utilities responses to the NRC Bulletin 88-01, and the results presented by Westinghouse and the Franklin Research Center from their examination of failed breakers, and

- to recommend appropriate activities which would effectively detect incipient age-related problems in breakers, and alleviate the pole weld cracking problem.

\subsection{Scope of Work}

An aging assessment of circuit breakers used in the nuclear industry was completed including the Westinghouse DS-series breakers. ${ }^{1}$ Various data bases were evaluated including Licensee Event Reports (LERs), Nuclear Plant Reliability Data System (NPRDS), In-Plant Reliability Data System (IPRDS), and Nuclear Plant Experience (NPE). The failure modes predominant in nuclear power plant applications were determined by sorting these operating experience data. Corresponding causes and mechanisms of failure were determined as well. The LER, 
NPRDS, and NPE data bases were further analyzed, augmenting the earlier assessment of circuit breakers. However, the emphasis of the study was placed on the Westinghouse DS-series breakers, particularly those used in reactor trip breaker (RTB) and other class $1 E$ applications.

It is important that the design, construction, and materials associated with the breakers are clearly understood. The operational instructions and characteristics of the circuit breakers are equally important in understanding the mechanism of subcomponent failures. Instruction manuals including schematics and manufacturer's maintenance manual were obtained to further analyze the effect of material aging during the service life of the breakers. This analysis was augmented by technical discussions with maintenance and service personnel from the electrical supply industry and with NRC inspectors involved in assessing breaker problems in nuclear power plants.

The responses of the utilities to the NRC Bulletin 88-01 on the problems associated with Westinghouse DS-breakers for Class 1E application were evaluated to determine the extent of the problem and the effectiveness of the recommended inspection criteria. This evaluation provided insights into the pole weld failures and their effects on other subcomponents within the breaker assembly. Depending on the results of the short-term and long-term inspections performed at plants with this particular series breakers, the current industry practices in response to NRC concerns are assessed.

Studies $^{2 \cdot 3}$ relating to DS-Breaker pole weld failures were conducted by the manufacturer and Franklin Research Center. Both determined the cause of the McGuire circuit breaker failure and assessed the generic nature of the problem. These results were evaluated for aging significance, as well as for other causes of breaker weld failures.

A DS-416 breaker was mechanical1y cycled for over 36,000 cycles to identify age-related degradation. During the test period, three pole shafts, with different weld configurations of the \#3 level weld, three operating mechanism assemblies, and several other parts were used as they were found to be inoperable. The results of this test program is described in detail in a Volume 2 of this NUREG. However, the conclusions obtained are used to formulate an effective maintenance program in alleviating age-related degradation problems that may occur due to breaker operation.

Section 2 of this report is devoted to a general understanding, construction, design, and principles of operation of the DS-series breaker. Section 3 summarizes the utilities responses to NRC Bulletin 88-01 on the short-term and long-term inspection of welds. Section 4 analyzes the data on operating experience and results from other studies, and provides the dominant failure modes, causes, and their mechanisms. The breaker service industry, as well as the manufacturer perspectives on breaker performance are discussed in Section 5 . Also included are interviews of individual utilities and other industries using DS-series breakers. Section 6 provides the current maintenance activities for these breakers and some suggested improvements to mitigate age-related degradations. Finally, Section 7 summarizes the results and makes recommendations for alleviating aging problems associated with these breakers. 


\section{WESTINGHOUSE DS-SERIES CIRCUIT BREARERS}

This section describes the design, construction, and basic operating principles of the DS-Series (DS-206 and DS-416) circuit breakers. The structural, mechanical, electrical, and instrumentation features are reviewed to provide understanding of the operations of this equipment. The operational characteristics of key subcomponents are further discussed. Failure of these subcomponents and their impact on the overall performance of the equipment are also discussed. Most of the information presented in this section is taken from Westinghouse bulletins and manuals on DS-series breakers. ${ }^{5-8}$

\subsection{Design and Construction}

A typical switchgear assembly consists of several components housing $2,4,6,8,10$, or 12 low-voltage power circuit breakers of the type DS-416 or DS206. A switchgear assembly for reactor trip breaker application contains four DS-416 circuit breakers, enclosed in two vertical free-standing metal structures that enclose the switchgear. The switchgear is designed to provide both redundancy for safety and flexibility for operation and maintenance. Figure 2.1 shows functional single-line diagram of a typical reactor trip switchgear assembly.

Al1 four of the circuit breakers are electrically and mechanically identical and interchangeable. However, once placed inside the racks in the switchgear enclosure, they become either main or bypass breakers, depending on their locations. These breakers receive control signals through two protection system power trains and separate interlocking systems. The main circuit breakers (RTA and RTB) are connected in a series to provide redundancy. Each of the two systems power trains can open (i.e., trip) a dedicated separate and independent main reactor trip breaker. The other two breakers (BYA and BYB) are bypass units, which allow on-line testing of the main circuit breakers by inserting and closing the associated bypass circuit breaker into the circuit. During normal operation, the main breakers are placed into service (in closed position) while the bypass breakers are placed in standby condition (in open position).

Unlike reactor trip breakers (RTBs) where the breakers are set to trip (or open) on command, all other Class 1E breaker applications to close the circuit and supply electric power to the driven equipment. Therefore, the modes of failures associated with RTBS can be different from those used for other Class $1 E$ applications. With the exception of standby equipment, most breakers remain in one state (i.e., open or close) for an extended period. For standby application, the equipment is required to run or stay at standby mode. Specifically, for charging pump application in PWR reactor facilities, these breakers experience a large number of open-close cycles because of the frequent demands on the Chemical Volume and Control System. 


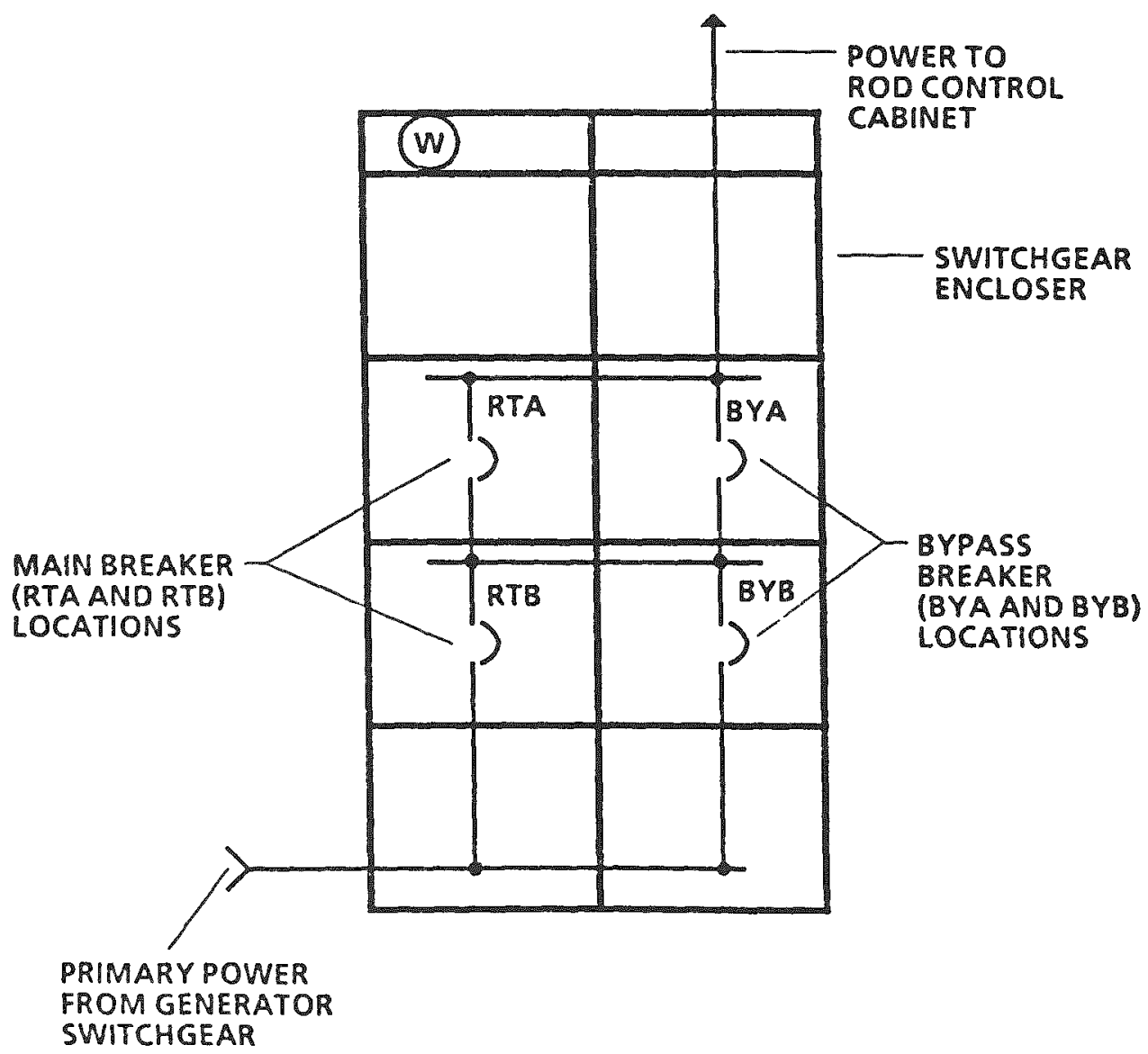

Figure 2.1 Functional Single Line Diagram of a Typical DS-416 Reactor Trip Switchgear Assembly

Each low voltage ( 600 volts or below) indoor or outdoor metal-enclosed switchgear unit has drawout, mounted-type DS-series air circuit breakers in breaker compartments. Figure 2.2 shows the front and rear views of a DS-416 breaker assembly. The DS-206 model looks similar except for the rear view contact fingers. The following subsections refer to the design and construction of a circuit breaker. 


\subsubsection{Structural Components}

A switchgear assembly shown in Figure 2.3 consists of the fixed part or stationary structure, that includes one or more free-standing units mechanically and electrically joined to make a single coordinated installation. Depending on the design requirements, each unit is divided into three or four compartments which contain the drawout-type air circuit breakers called the removable elements (Figure 2.4). Sometimes, various compartments are used for auxiliary equipment. The hinged door supports instrumentation devices such as meters, and relays. Each breaker has finger clusters that engage the stationary main contact stabs at the rear of the compartment when in the connected position.

The breaker compartment has four positions of the removable element; "CONNECTED," "TEST,", "DISCONNECTED", and "REMOVE." In the "CONNECTED" position, both primary and secondary disconnecting devices are engaged and the circuit breaker is ready for operation. In the "TEST" position, only the secondary disconnecting devices are engaged, and the circuit breaker can be operated without energizing the power circuit. In the "DISCONNECTED" position, both primary and secondary disconnecting devices are disengaged, and the entire circuit breaker is isolated and can be pulled out. In the "REMOVED" position the breaker element is not held by the levering mechanism and is not connected electrically or mechanically to the switchgear cell. The breaker is free to roll out onto the extension rails. The secondary disconnecting contacts connect the control circuit when in "TEST" and "CONNECTED" positions. The breaker cannot be pulled out from "DISCONNECTED" position. If must be in the fourth or "REMOVED" position.

The design of the circuit breakers is similar whether the installation is indoors or outdoors; in general, outdoor switchgear is enclosed in a weatherproof enclosure.

The cabinet of the switchgear is divided into three sections from front to rear, and contains the circuit breakers in the breaker compartments which are in front of a bus compartment. The cable compartment is located behind the bus compartment. The bus compartment has a welded aluminum bus bar that runs vertically and feeds all breaker compartments in the cabinet. The main structure is formed from a welded heavy-gauge sheet metal. The bus and cable compartments are usually ventilated via the grillwork at the bottom of the bolted rear sheets. The air leaves through a grill in the bus compartment roof and grill openings near the top of the rear sheets.

Ring-type current transformers are positioned around the stationary main contacts for metering purposes. Each transformer is bolted to the molded glass polyester of the main contact support plates. 
The weight of a typical low-voltage switchgear unit without the breakers ranges from 900 to $1050 \mathrm{lbs}$, depending on whether it is three- or four-units high, and whether aluminum or copper bus bars are used. The DS-206 and DS-416 circuit breakers weigh from 168 lbs. to $180 \mathrm{lbs}$. each. Generally, these units are anchored against seismic loads by fastening them to steel channels embedded in a concrete floor. They may be bolted or welded to the floor channels.

\subsubsection{Mechanical Components}

The complete drawout element includes the circuit breaker and its auxiliaries. The circuit breaker has three major components:

- the power operated mechanism,

- the contacts, operated by the mechanism,

- the arc chutes, which interrupt the arc when the breaker is opened under load or short-circuit conditions.
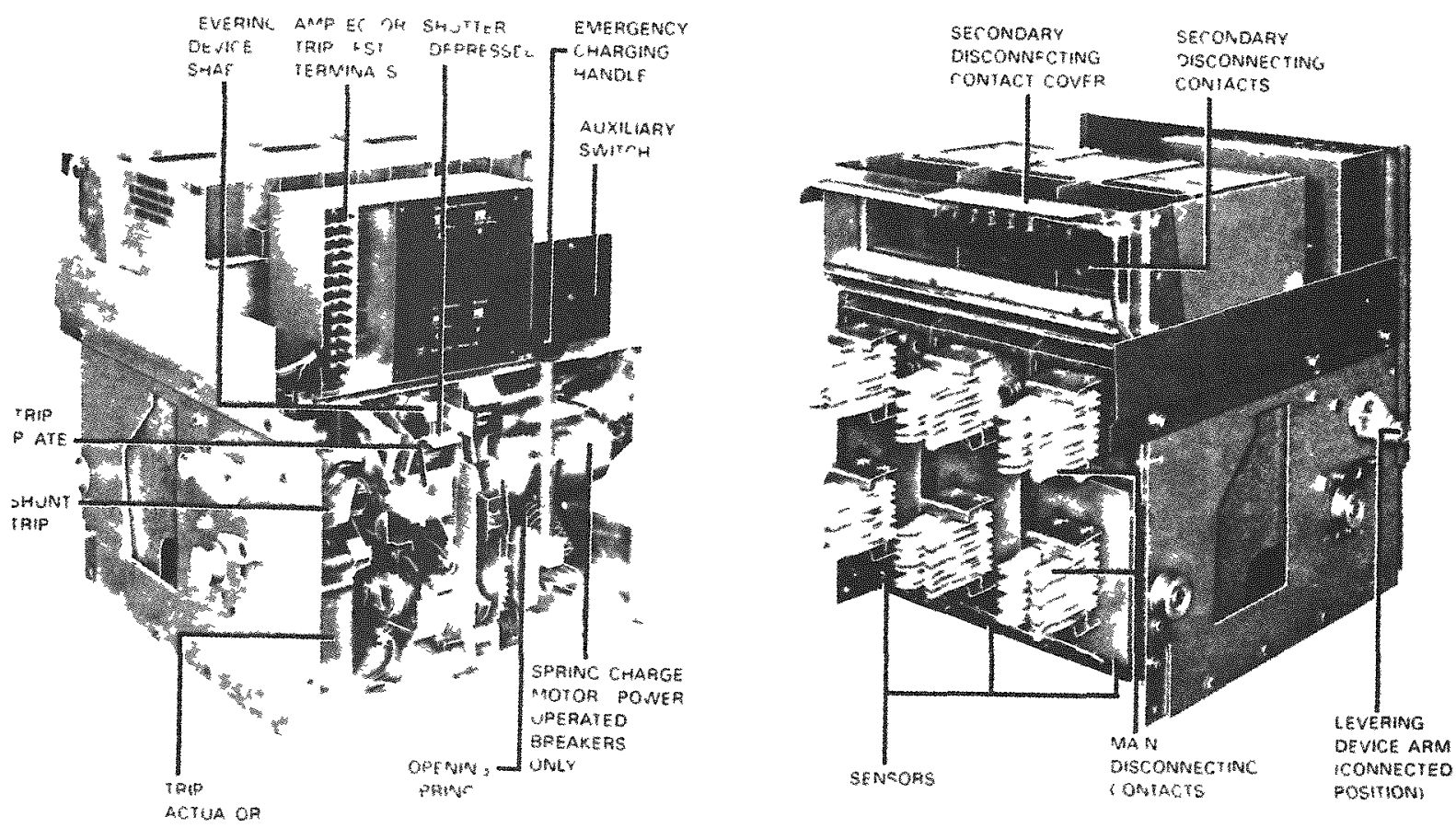

Figure 2.2 DS-416 Breakers (the DS-206 is similar) 

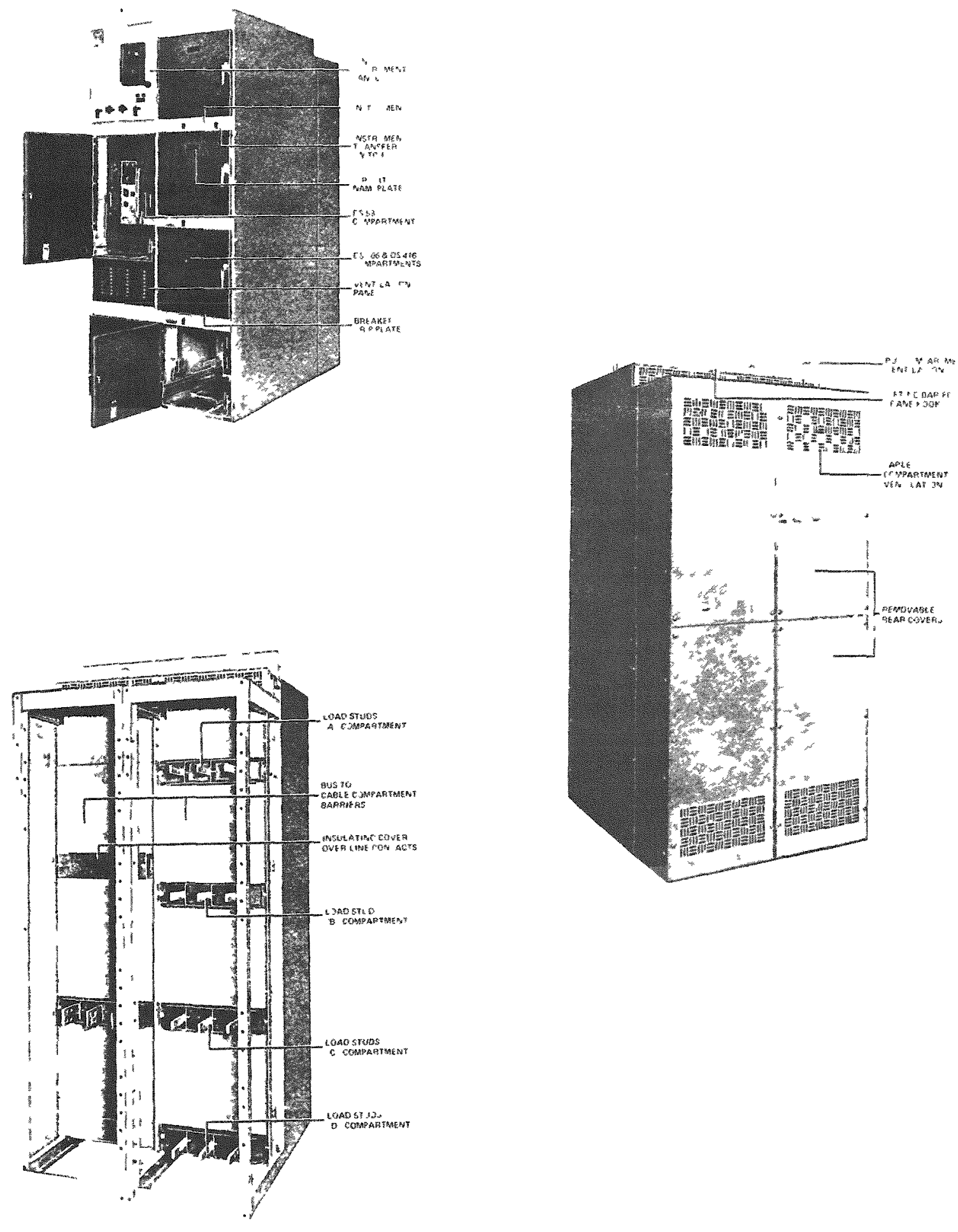

Figure 2.3 Structural Components of a Switchgear Assembly 



Figure 2.4 Type DS-206/DS-416 Breaker Position in a Switchgear Assembly $2-6$ 
The auxiliary components include interphase barriers, drawout element frame and rollers, the leveling device, main disconnecting contacts, the secondary contacts, the interlocks, drawout element position indicator, open-close indicator, spring charge indicator, and the close bar and trip plate. All of these major and auxiliary components are assembled in a frame, as shown in Figure 2.2.

\section{Power Operated Mechanism}

The power operated mechanism is of the spring stored-energy type, consisting of two major parts:

1) the stored energy or spring charging mechanism, and

2) the mechanism for closing and opening the breaker.

There are two basic mechanisms for the DS-Iine of breakers: power operated and manually operated. The manually operated breakers are not in use for class 1E applications. The prime difference between the two charging mechanisms is that the power-operated one is equipped with a universal-type motor for automatic charging the closing spring (Figure 2.5). The breaker is also equipped with a spring-release device for electrical closing through a control switch or other circuit-making device for remote closing. A shunt-trip and under-voltage trip devices are used for remote tripping through a control switch or relay. Both types can be charged by hand. The breaker can be closed by means of the close bar. Also, both types or breakers can be opened with the trip plate.

Figure 2-6 shows the principal parts and linkages involved in closing and opening the breaker. The closing mechanism is of the general variety of mechanically trip-free mechanisms, meaning that the breaker can be opened or tripped free from this closing mechanism at any point in its closing stroke. Also, if the trip latch is held in the "trip" position while the spring release latch is released, the closing spring will make a trip-free operation, but the breaker contacts will not close nor move appreciably toward the closed position. With the trip shaft in the trip position, there is no restraint on the trip latch, and therefore, no force is applied to the main link to close the breaker.

The trip shaft can be rotated to trip the breaker by manipulating the following:

- by pushing on the trip plate on the breaker panel,

- by shunt trip device,

- by action of the actuator energized by the sensor,

- by pushing the trip button on the front of the breaker compartment door, providing the breaker is in the connected position, and

- by using an undervoltage trip device as an accessory. 


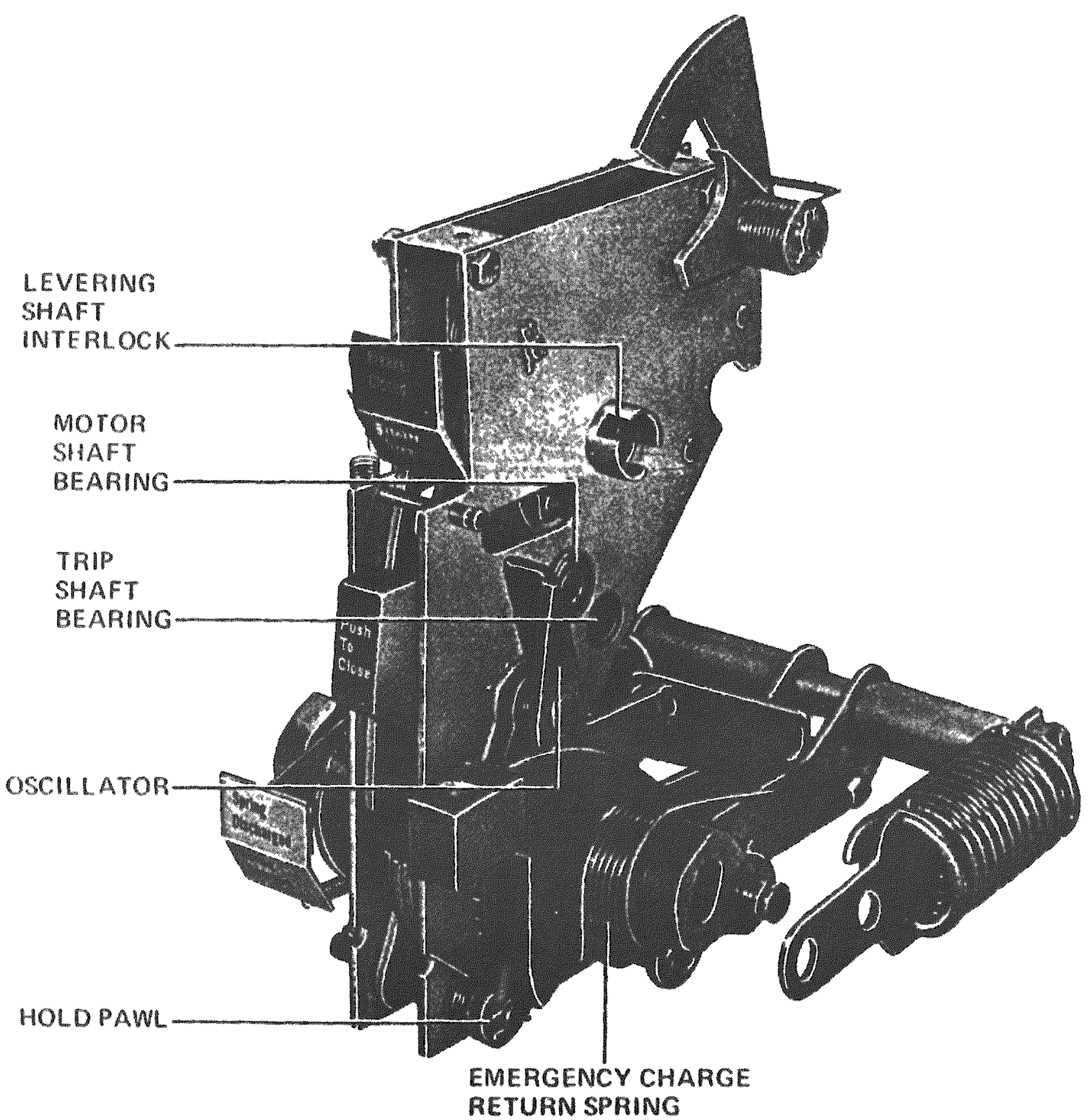

Flgure 2.5 Operacing Mechanisms 


\section{Contacts}

The DS-206 has the three poles mounted on a single molded base of high strength insulating material, on which the contact parts and sensors are mounted (Figure 2.7). Each of the three poles of the DS-416 is mounted on an individual insulating base, and all three poles held in accurate alignment by a welded steel frame.

The moving contact members of both units consist of blades hinged at the bottom to the lower main terminal through control and pressure rotating contacts, and with the main and arcing contacts at the upper end. The design of the arcing contacts for these units is similar; the number of blades, the size of the main terminals and the number of fingers in the main disconnecting contacts vary with the unit's ratings.

All stationary main contacts which carry the main continuous load current are of the butt type, composed of a multiplicity of fingers. Each finger is hinged at the upper end under controlled pressure. The stationary arcing contacts consist of two parallel fingers, one on each side of the stationary terminal member. The moving arcing contact wedges the stationary contact fingers apart as the breaker closes.

\section{Arc Chutes}

The arc chute fits well down over the arcing contacts so that the arc is always confined inside the chute for all levels of current. Immediately above the arcing contacts in the arc chute, are one-speed vertical steel splitter plates arranged crosswise and having an inverted " $V$ " notch to attract the arc and interrupt it by cooling. The DS-206 breakers use smaller size arc chute units than the DS-416 breakers. The larger units include sheets of hard arcresisting plastic plates, which produce turbulence in the exhaust gasses above the steel plates and prevent electrical breakdown over the top of the arc chute or to ground.

\subsubsection{Electrical and Electronic Components}

The circuit breaker is tripped on overload and under short-circuit conditions by the combined actions of three components (Figure 2.8). These components include the sensors, the Amptector solid state trip unit, and the actuator. All tripping functions are performed by a secondary control circuitry, and there is no mechanical or direct magnetic action between the primary current and the mechanical tripping parts of the breaker.

\section{The Amptector Trip Unit}

The amptector operates on low-level signals from current sensors, eliminating the electro-mechanical series overcurrent trip units. Solid-state tripping action is achieved by the combined action of this unit with the sensors and the trip actuator. The amptector has a maximum of six different combinations of adjustable controls and the ground current time has adjustable pickup and delay. There are settings for the following characteristics: 


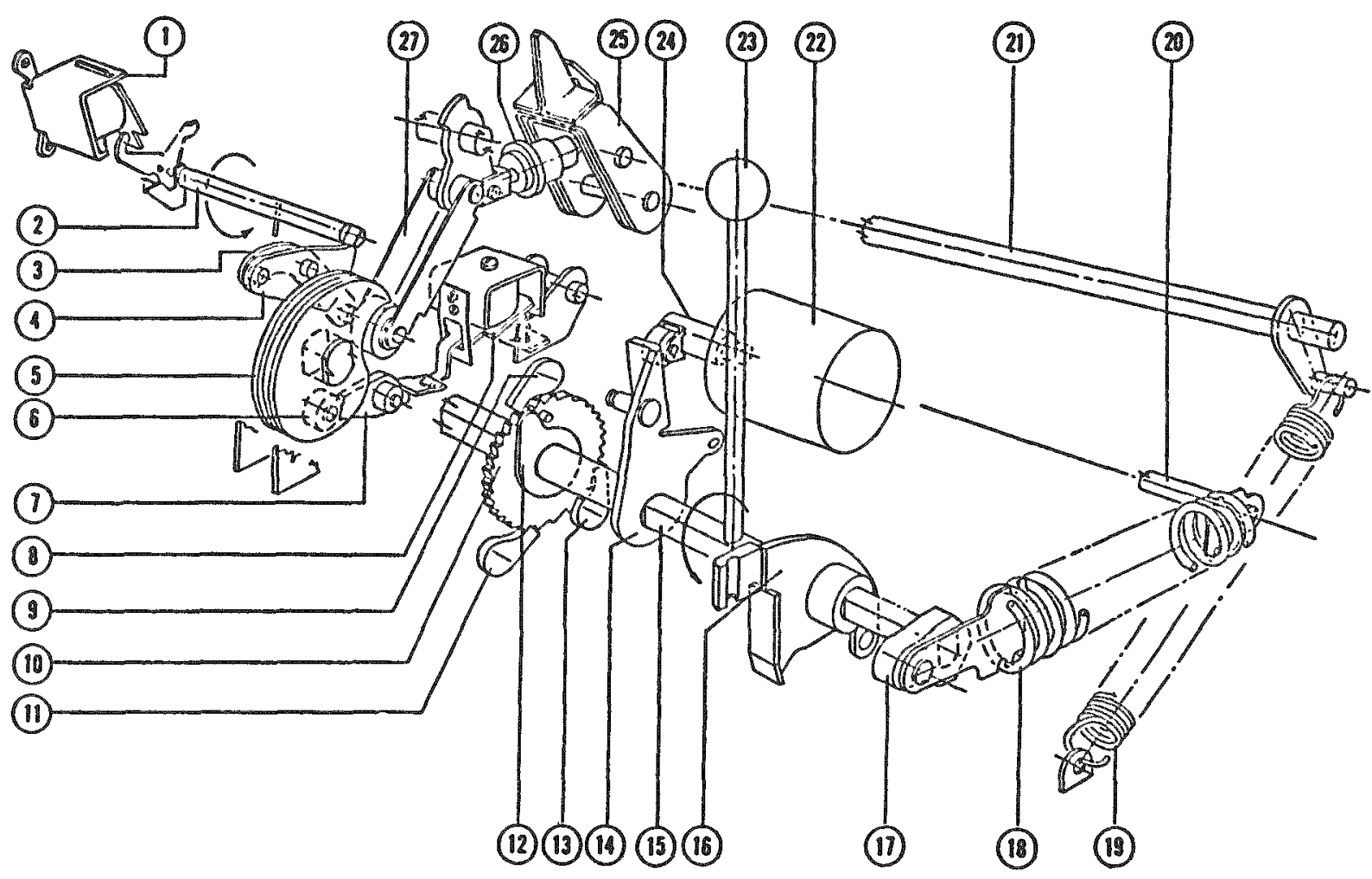

\author{
1. SHUNT TRIP DEVICE \\ 2. TRIP SHAFT \\ 3. ROLLER CONSTRAINING LINK \\ 4. TRIP LATCH \\ 5. CLOSE CAM \\ 6. STOP ROLLER \\ 7. SPRING RELEASE LATCH \\ 8. SPRING RELEASE DEVICE \\ 9. OSCILLATOR PAWL
}

10. RATCHET WHEEL

11. HOLD PAWL

12. DRIVE PLATE

13. EMERGENCY CHARGE PAWL

14. OSCILLATOR

15. CRANK SHAFT

16. EMERGENCY CHARGE DEVICE

17. CRANK ARM

18. CLOSING SPRING
19. RESET SPRING

20. CLOSING SPRING ANCHOR

21. POLE SHAFT

22. MOTOR

23. EMERGENCY CHARGE HANDLE

24. MOTOR CRANK AND HANDLE

25. MOVING CONTACT ASSEMBLY

26. INSULATING LINK

27. MAIN DRIVE LINK

Figure 2.6. Arrangement of the Principal Parts of a Completely Power Operated Mechanism (the close spring is shown in the charged position) 


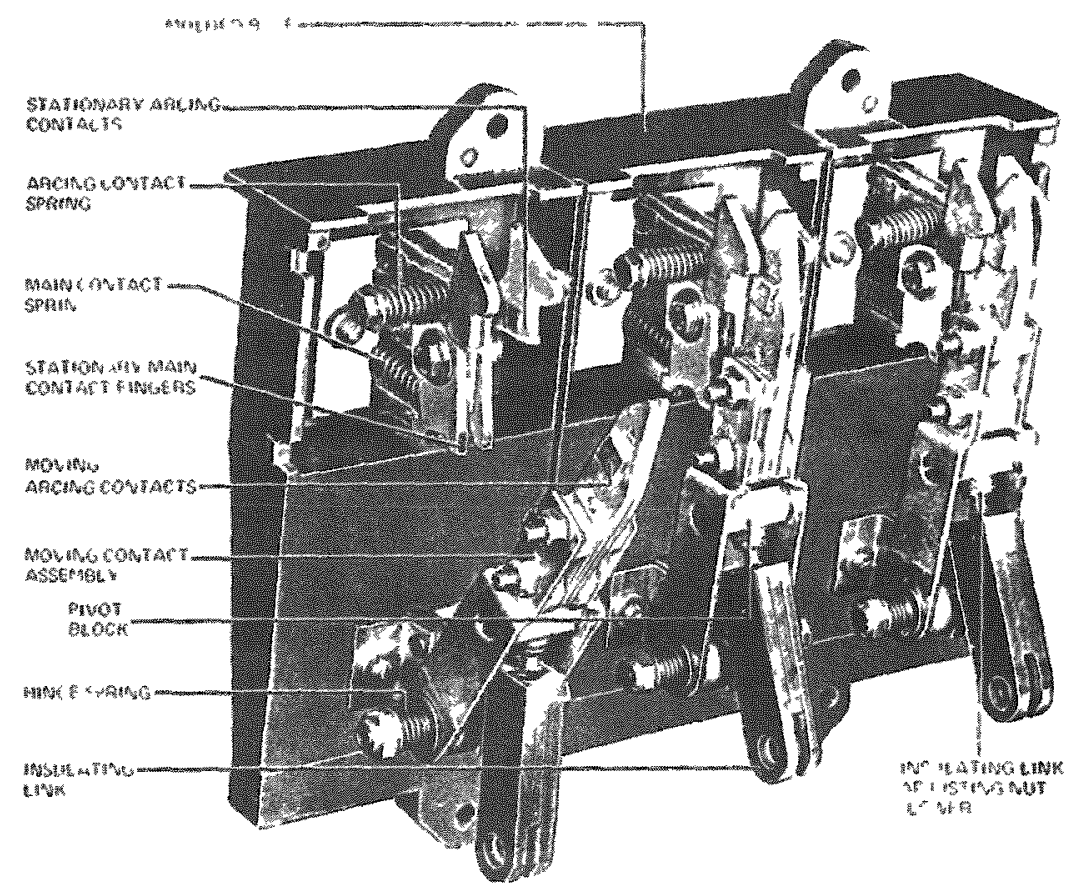

Figure 2.7. Type DS-206 Pole Unit Assembly - Front View

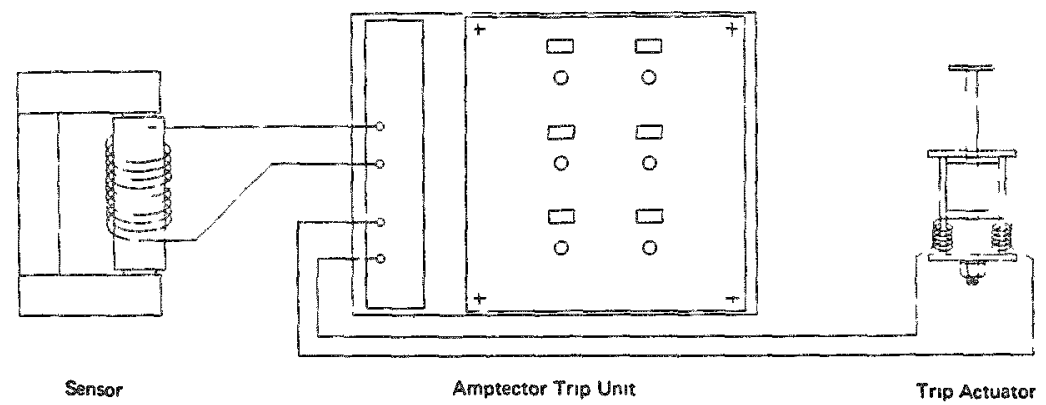

Figure 2.8. Schematic Illustration of Tripping System 
- Long-delay current pick-up (.5 to 1.25 \& sensor rating)

- Long-delay ( 4 to 36 seconds, at $6 \mathrm{x}$ rating)

- Short-delay current pick-up ( 4 to $10 \mathrm{x}$ sensor rating)

- Short-delay (*.18 seconds to .50 seconds or 11 to 30 cycles at $60 \mathrm{~Hz}$, at $2.5 \mathrm{x}$ pick-up settings)

- Instantaneous current pick-up ( 4 to $12 \mathrm{x}$ sensor rating)

- Ground current time, with non-adjustable current pick-up

The ranges of current settings in multiples of sensor rating and time delay for the above six settings are given in brackets. Any of the six combinations of three pick-up ranges and the three time ranges may be used.

\section{Sensors}

Three sensors are located at the rear of the breaker on the lower studs, and directly behind the main disconnection contacts (Figure 2.2). They produce an output proportional to the load current, and furnish the Amptector trip unit with signals and energy to trip the breaker when the pre-selected current magnitude and duration are exceeded.

\section{Actuator}

The amptector continuously monitors current output from "sensors" (current transformers) mounted on each phase of the breaker. When the output reaches a predetermined setting, the amptector responds by supplying a pulse of current to the actuator. The actuator receives a txipping pulse from the Amptector trip unit, and produces a mechanical force to trip the breaker. The tripping mechanism is made up of a permanent magnet, a disc held by the magnet, a rod acted on by a spring, a lever for tripping the breaker, and lever for mechanically resetting the actuator. A tripping pulse from the Amptector trip unit counteracts the effect of the permanent magnet, allowing the spring to separate the disc from the magnet and move the rod to actuate the trip-shaft lever. The trip shaft lever then rotates the trip-shaft and trips the breaker.

\subsubsection{Optional Accessories} breaker:

Several optional accessories are available for special applications of a

1) Undervoltage Trip Attachment (UVTA): The undervoltage trip is an electro-mechanical device that trips the circuit breaker when the voltage on its coil falls to between 30 and 60 percent of normal. The standard unit trips instantaneously. This device is typically used for reactor trip applications. 
2) Overcurrent Trip Switch: The function of an overcurrent trip switch is to provide a signal when the breaker has tripped open by action of the Amptector trip unit due to phase-or ground-overcurrent. Normal tripping by the trip plate, shunt trip device, or UVTA, does not operate the overcurrent trip switch.

3) High-Load Switch: This switch is a self-resetting solid state device which picks up on an overload condition at a lower pick-up value than the setting of the breaker overload trip on the Amptector trip unit. Its function is to give advance notice of an overload condition before the breaker trips.

\subsection{Principles of Breaker Operation}

The breaker can be closed or tripped manually. Also, it can be operated electrically when the breaker element has the required control power applied to its control circuit and receives the respective control signal required to close or trip. Sensing the control signal can be by remote automatic control logic, a remote control switch, or a local pushbutton.

\subsubsection{Closing Operation}

To close the circuit breaker element, the power-operated (stored-energy) mechanism must be in the charged condition. In case the control power is not available to the motor charging circuit, the stored-energy mechanism can be charged manually by using the manual spring charge handle. At the end of the last spring-charging stroke, the mechanism roller containing link rotates the breaker trip latch from the trip position to the reset position. When the breaker is in the "CIIARGED" condition and is not held in the trip-free condition by the UVTA or other mechanical interlocks, the breaker can be closed by manually depressing the breaker's close bar, which operates the spring release latch to release the breaker closing springs. The springs discharge, causing rotation of the close cam to close the breaker.

To electrically charge the store-energy mechanism, the secondary contacts of the breaker are engaged with the appropriate control power when the breaker element is in the OPEN position. When the closing spring is fully charged by the motor, the motor cut-off (limit) switch opens, de-energizing the spring charging motor. To close the breaker element electrically, the UVTA must be energized, the power-operated (stored energy) mechanism must be in CHARGED condition, and the spring-release device must receive a close signal. The breaker closes in the manner discussed earlier.

\subsubsection{Tripping (Opening) Operation}

The breaker element can be manually tripped by rotating of the breaker trip shaft which unlatches the trip latch, causing the breaker pole units to open. This process can be achieved in two ways. One way is by depressing the trip plate which pushes on the trip pin located on the breaker trip shaft, rotating the trip shaft. The second method utilizes the trip plate located on the cell door; this plate is only operable with the breaker in the CONNECTED position. 
The breaker can be tripped electrically by three methods: (1) operation of the UVTA, (2) the Shunt Trip Attachment (STA), and (3) by using the Direct Trip Actuation. The first approach functions when there is a loss or drop of between 30 to 60 percent of rated dc voltage to the UVTA. The trip lever tab of the UVTA trip lever strikes the trip pin of the breaker trip shaft, rotating the shaft to trip the breaker. The second method is by energizing the normally de-energized STA, which causes the armature to push the trip lever on the breaker trip shaft, causing the breaker to trip. The third method involves Direct Trip Actuator used with the amptector. 
NRC Bulletin 88-01, February 5, 1988, required that al1 licensees using the Westinghouse DS series circuit breakers in Class $1 E$ service inspect the pole shaft welds, and the alignment of the breaker closing mechanism, and document the findings. BNL reviewed the responses that were available during February 1989; the results are summarized in this section.

\subsection{Required Inspections and Acceptance Criteria}

Bulletin 88-01 addresses the inspection of the seven pole shaft welds (see Figure 3.1) in two groups, designated as short-term and long-term inspections. The short-term inspections include the critical welds at the three main pole levers (welds 2, 3, and 6 in Figure 3.1), and the center pole lever which receives the major forces during the opening or closing of the breaker. The welds designated for short-term inspections are important in maintaining the alignment of the moving parts associated with the breaker's closing mechanism. The long-term inspections address the four remaining pole shaft welds (welds 1 , 4, 5, and 7 in Figure 3.1), and check the alignment of the breaker's closing mechanism. The timing and acceptance criteria for each inspection are discussed in the following subsections.

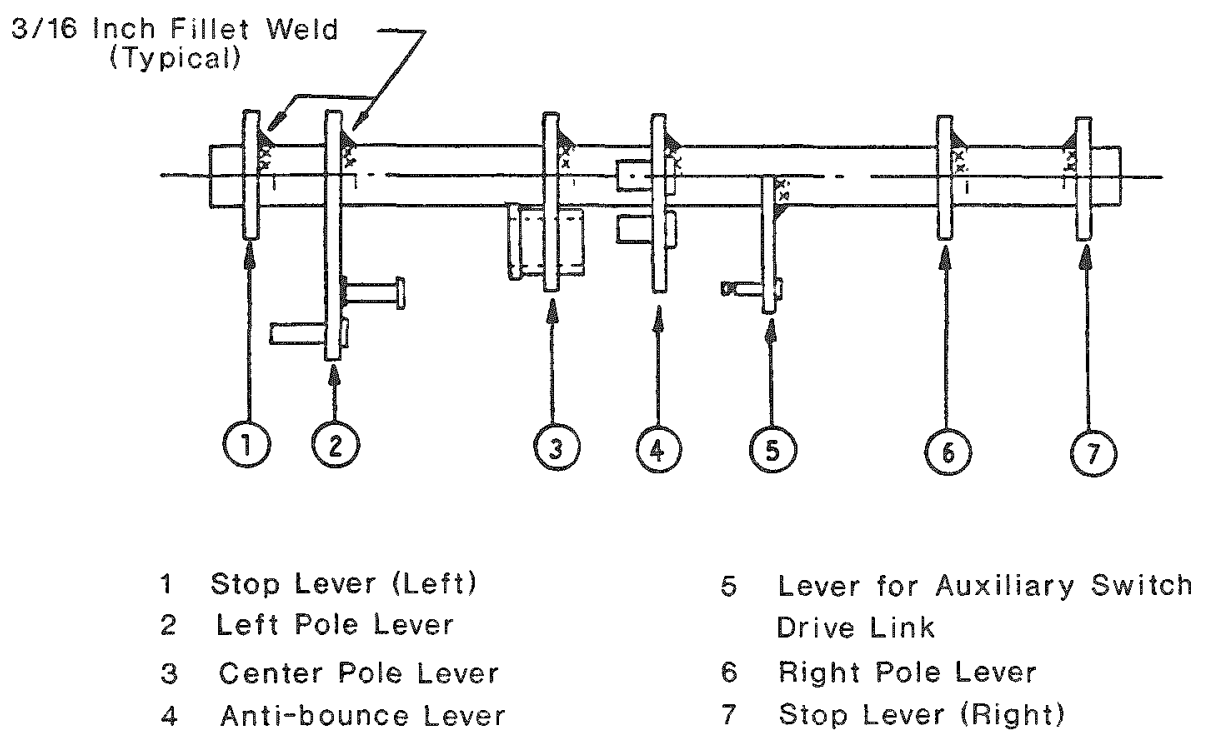

Figure 3.1 Pole Shaft Assembly 


\subsubsection{Short-term Inspections}

The short-term inspections were to be scheduled as soon as possible, during a maintenance outage or during the next breaker surveillance test. Reactor trip breakers were an exception, and had to be inspected within 30 days of receiving Bulletin 88-01. The purpose of the inspections was to evaluate the weld's fusion, size and length, and to look for cracks and porosity. Two sets of acceptance criteria for welds were established. Breakers that satisfy the more stringent criteria (referred to as Criteria 6.1.1 in the bulletin and this report) are acceptable for service until the next required breaker refurbishment (i.e., due to wear, damage, or service years). Breakers that fail the more stringent criteria but pass the second criterion (referred to as criteria 6.1.2 in the bulletin and this report) can be kept in service for up to 4000 cycles of operation, with a reinspection every 200 cycles. (A second criterion is imposed for breakers subjected to higher short-circuit current, which require a reinspection following each occurrence of a high-current event.) Breakers that fail all of the short-term criteria must have the pole shaft replaced before continued service. Replacement pole shafts must pass the more stringent of the short-term criteria. Table 3.1 summaries the acceptance criteria for short-term inspections.

\subsubsection{Long-term Inspections}

The long-term inspections addressed the remaining four pole shaft welds and were required to be performed before the restart following the next refueling outage by Bulletin 88-01. The acceptance criteria (referred to as Criteria 7.1 in the Bulletin and this report) are shown in Table 3.2 , and are almost the same as the less stringent short-term criteria.

Failure to meet these criteria requires the replacement or refurbishment of the pole shaft. One exception is the pole shaft lever associated with the Auxiliary Switch Drive Link (weld 5 in Figure 3.1) has a light loading. This joint need only be checked for fusion of the weld.

In addition to inspecting weld characteristics, the long-term inspection also includes a detailed verification of the alignment of the breaker mechanism. To check the alignment, the breaker must be removed and partially disassembled. The Bulletin does not specify remedial actions, but recommends seeking assistance from Westinghouse. As part of the long-term inspection, Bulletin 88-01 requires this alignment check to be performed during the next refueling outage.

\subsection{Results of the Review of Utility Responses}

This summary of 1 icensee responses to Bulletin 88-01 includes information up to February 1989. To that date, 110 plant units responded to the bulletin. Al1 plants except Sequoyah Unit 2 operated by Tennessee Valley Authority (TVA) were excluded from this 1ist; among those excluded were Bellefont Units 1 \& 2 , Browns Ferry Units 1, $2 \& 3$, Watts Bar Units $1 \& 2$, and Sequoyah Unit 1 . Out of the 110 plant units, 77 units had no DS-series breakers in Class $1 \mathrm{E}$ service (Table 3.3). Table 3.4 lists the inspection results from the remaining 33 plant units that have DS breakers in service. 
Table 3.1 Short-term Inspection Criteria

\begin{tabular}{|c|c|c|}
\hline & $\begin{array}{l}\text { Acceptable for } \\
\text { Continued Service }\end{array}$ & $\begin{array}{c}\text { Acceptable with } \\
\text { Reinspection Every } 200 \text { Cycles }\end{array}$ \\
\hline Weld Size & $3 / 16$ inch fillet & \multirow[b]{2}{*}{$\begin{array}{c}3 / 16 \text { inch fillet for } 90 \text { degree } \\
\text { continuous around shaft } \\
\text { or } \\
1 / 8 \text { inch fillet for } 120 \\
\text { degree continuous }\end{array}$} \\
\hline Weld Length & $\begin{array}{l}180 \text { degree continuous } \\
\text { around shaft }\end{array}$ & \\
\hline Fusion & $\begin{array}{c}\text { Fused over entire } \\
\text { length }\end{array}$ & Fused over entire length \\
\hline Cracks & None & None \\
\hline Porosity & $\begin{array}{l}\text { Surface pin holes with } \\
\text { cumulative diameter } \\
\text { less then } 1 / 16 \text { inch } \\
\text { per inch weld }\end{array}$ & $\begin{array}{l}\text { Surface pin holes with } \\
\text { cumulative diameter less than } \\
1 / 16 \text { inch per inch weld }\end{array}$ \\
\hline
\end{tabular}

Table 3.2 Long-term Inspection Criteria

\begin{tabular}{|l|l|}
\cline { 2 - 2 } \multicolumn{1}{c|}{} & \multicolumn{1}{c|}{ Acceptable for Continued Service } \\
\hline Weld Size and Length & $\begin{array}{l}3 / 16 \text { inch fillet for a minimum of } 90 \\
\text { degrees continuous or } 1 / 8 \text { inch fillet for } \\
\text { a minimum of } 120 \text { degrees continuous. }\end{array}$ \\
\hline Fusion & Good fusion along both legs of the weld. \\
\hline Cracks & None \\
\hline Porosity & $\begin{array}{l}\text { Surface pin holes with less than } 1 / 16 \text { inch } \\
\text { cumulative diameter }\end{array}$ \\
\hline
\end{tabular}


Table 3.3 Plants Having No DS-Series Breakers in Class $1 E$ Applications

Arkansas Units $1 \& 2$ Beaver Valley Unit 1 Big Rock Point Brunswick Units $1 \& 2$ Big Rock Point Clinton

Cook Units $1 \& 2$ Cooper Crystal River Unit 3 Davis Besse Diablo Canyon Units $1 \& 2$ Dresden Units $2 \& 3$ Duane Arnold Fermi Unit 2 Fitzpatrick Fort Calhoun Fort St. Vrain Ginna Grand Gulf Unit 1 Haddam Neck Hatch Units $1 \& 2$ Hope Creek Indian Point Unit 2 Kewaunee La Salle Units $1 \& 2$ Limerick Unit 1 Maine Yankee Millstone Units $1 \& 2$
Monticello

Nine Mile Point Units $1 \& 2$ North Anna Units $1 \& 2$

Oconee Units $1,2 \& 3$

Oyster Creek

Palisades

Peach Bottom Units $2 \& 3$

Perry Unit 1

Pilgrim Unit 1

Point Beach Units $1 \& 2$

Prairie Island Units $1 \& 2$

Quad Cities Units $1 \& 2$

Rancho Seco

River Bend Unit 1

Robinson Unit 2

Salem Units $1 \& 2$

San Onofre Units $1,2 \& 3$

Shoreham

St. Lucie Units $1 \& 2$

Surry Units 1 \& 2

Susquehana Units $1 \& 2$

TMI Unit 1

Trojan

Turkey Point Units $3 \& 4$

Vermont Yankee

Waterford Unit 3

Yankee Rowe 
With the exception of Calvert Cliffs Units $1 \& 2$ and Palo Verde Units 1 , 2 , \& 3, all other PWR units that have DS-series breakers in CIass 1E applications are Westinghouse plants. The NSSS vendor for these two plants is Combustion Engineering (CE). The only boiling water reactor (BWR) plant using DS-breakers is the WNP Unit 2 operated by Washington Public Power Supply System (WPPSS). Neither unit at Calvert Cliffs uses these breakers for their reactor trip applications. However, all three units at Palo Verde utilize DS-416 breakers as their reactor trip breakers. Almost all Westinghouse plants using DS-breakers in the plant have used DS-416 breakers as their reactor trip breakers. Although the list in Table 3.4 summarizes only plants having DSseries breakers in Class $1 \mathrm{E}$ application, a larger number of plants utilize these breakers for non-Class 1E applications. Failure of these breakers may not directly affect the safety operation of the plants; however, they could introduce unexpected transients in the safety systems.

Based on these responses, the following plants have a large population of DS-breakers used for class $1 \mathrm{E}$ applications:

\author{
Calvert Cliffs Unit $1 \& 2$ \\ Comanche Peak Units $1 \& 2$ \\ Farley Units 1 \& 2 \\ Indian Point Unit 3 \\ South Texas Units $1 \& 2$ \\ WNP Unit 2 \\ Zion Unit 1
}

We expect that there are similar numbers of DS-breakers in use at Braidwood Units $1 \& 2$, Byron Units $1 \& 2$, and Zion Unit 2 although we have no information on the status of theix DS-breakers.

The results shown in Table 3.4 show that over $80 \%$ of breakers failed the 6.1.1 or other criteria. Since Criterion 6.1.1 represents the original design configuration of the breakers, the number of failures represents the number of breakers that do not meet the original requirements of breaker design.

Not all of the breakers that failed the Criteria 6.1.1 test were tested against Criteria 6.1.2. In some cases, licensees replaced the pole shafts based on the 6.1.1 test results. However, $40 \%$ of the breakers that were tested for 6.1 .2 after failing criteria 6.1 .1 , satisfied the second criteria. Nevertheless, this high percentage of failures clearly indicates that there was a large number of substandard welds on the breaker. 
Table 3.4 Responses of Utilities with DS Breakers for Class 1E Service (February 1989 ) a. Short Term Inspection Results

\begin{tabular}{|c|c|c|c|c|c|c|c|c|c|}
\hline \multirow[b]{2}{*}{ Plant Name } & \multicolumn{2}{|c|}{$\begin{array}{l}\text { In Service \& } \\
\text { Spare Breakers }\end{array}$} & \multicolumn{2}{|c|}{$\begin{array}{l}\text { Breakers } \\
\text { Inspected }\end{array}$} & \multicolumn{2}{|c|}{$\begin{array}{c}\text { Passed Criteria } \\
6.1 .1\end{array}$} & \multicolumn{2}{|c|}{$\begin{array}{l}\text { Passed Criteria } \\
\quad 6.1 .2\end{array}$} & \multirow{2}{*}{ Remarks } \\
\hline & DS-206 & $D S-416$ & DS-206 & $0 S-416$ & $0 S-206$ & $0 S-416$ & $D S-206$ & $0 S-416$ & \\
\hline $\begin{array}{l}\text { Beaver Valley Unit } 2 \\
\text { Braidwood Units } 1 \& 2 \\
\text { Bypon Units } 1 \text { \& } 2\end{array}$ & $\begin{array}{l}0 \\
-\end{array}$ & 4 & MA & $\begin{array}{l}2 \\
-\end{array}$ & $\begin{array}{c}\text { NA } \\
\vdots \\
-\end{array}$ & $\begin{array}{l}0 \\
-\end{array}$ & $\begin{array}{c}\text { MA } \\
:\end{array}$ & $\begin{array}{l}2 \\
- \\
-\end{array}$ & Ho information available. \\
\hline $\begin{array}{l}\text { Callaway Unit } 1 \\
\text { Calvert cliffs Unit } 1 \\
\text { Calvert cliffs Unit } 2 \\
\text { Catawba Units I \& } 2 \\
\text { Conanche Peak Units } 182\end{array}$ & $\begin{array}{r}0 \\
43 \\
44 \\
0 \\
0\end{array}$ & $\begin{array}{r}8 \\
10 \\
10 \\
8 \\
48\end{array}$ & $\begin{array}{l}\text { NA } \\
43 \\
44 \\
\text { NA } \\
\text { NA }\end{array}$ & $\begin{array}{r}8 \\
10 \\
10 \\
4 \\
-\end{array}$ & $\begin{array}{r}\text { MA } \\
1 \\
0 \\
\text { MA } \\
\text { MA }\end{array}$ & $\begin{array}{l}0 \\
9 \\
0 \\
3 \\
0\end{array}$ & $\begin{array}{l}\text { MA } \\
\text { NP } \\
30 \\
\text { NA } \\
\text { NA }\end{array}$ & $\begin{array}{r}4 \\
\text { NP } \\
9 \\
3 \\
9\end{array}$ & $\begin{array}{l}\text { Models not identified. Assumed to be DS-496. } \\
\text { Inspections will be done prior to fuel load. }\end{array}$ \\
\hline $\begin{array}{l}\text { Farley Unit } 1 \\
\text { Farley Unit } 2\end{array}$ & 58 & $\begin{array}{r}13 \\
4\end{array}$ & $\begin{array}{l}58 \\
\text { MA }\end{array}$ & $\begin{array}{r}13 \\
4\end{array}$ & WA & 2 & $\begin{array}{l}19 \\
M A\end{array}$ & $\begin{array}{l}6 \\
1\end{array}$ & $\begin{array}{l}\text { Unit } 2: \text { only RTB information available } \\
5 \text { shafts will be replaced when avallable. }\end{array}$ \\
\hline Herp is Unit 1 & - & RTRS & NA & RTEs & MA & ALL & MA & MP & Breaker population not available \\
\hline Indian Point Unit 3 & 0 & 32 & 0 & 32 & 0 & 2 & 0 & 28 & \\
\hline $\begin{array}{l}\text { McGuire units } 1 \text { \& } 2 \\
\text { Millstone Unit } 3\end{array}$ & 0 & $\begin{array}{l}8 \\
4\end{array}$ & $\begin{array}{l}\text { NA } \\
\text { NA }\end{array}$ & 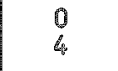 & $\begin{array}{l}\text { MA } \\
\text { MA }\end{array}$ & $\stackrel{A P}{0}$ & NA & AP & \\
\hline $\begin{array}{l}\text { Palo Verde Unit } 1 \\
\text { Palo verde Unit } 2 \\
\text { Palo verde Unit } 3\end{array}$ & $\begin{array}{l}0 \\
0 \\
0\end{array}$ & $\begin{array}{l}2 \\
2 \\
2\end{array}$ & $\begin{array}{l}\text { MA } \\
\text { MA }\end{array}$ & $\begin{array}{l}2 \\
\frac{2}{2} \\
2\end{array}$ & $\begin{array}{l}\text { NA } \\
\text { NAA } \\
\text { NAA }\end{array}$ & $\begin{array}{l}2 \\
1 \\
0\end{array}$ & $\begin{array}{l}\text { NA } \\
\text { MA } \\
\text { NA }\end{array}$ & $\begin{array}{r}\text { NA } \\
1 \\
2\end{array}$ & 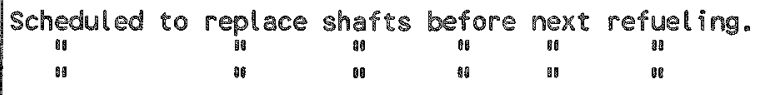 \\
\hline $\begin{array}{l}\text { Sea Brook Unit } 1 \\
\text { South Texas Unit } 1 \\
\text { South Texas Unit } 2 \\
\text { Summer Unit 1 } \\
\text { Sequoyah Unit } 2\end{array}$ & $\begin{array}{r}0 \\
35 \\
35 \\
0 \\
W R \\
\end{array}$ & $\begin{array}{r}5 \\
17 \\
17 \\
5 \\
012 \\
\end{array}$ & $\begin{array}{l}\text { MA } \\
\text { NR } \\
35 \\
\text { NA } \\
15\end{array}$ & $\begin{array}{r}5 \\
4 \\
17 \\
5 \\
-\end{array}$ & $\begin{array}{r}\text { NA } \\
\text { NR } \\
1 \\
\text { NA } \\
5 \\
\end{array}$ & $\begin{array}{l}0 \\
2 \\
3 \\
0 \\
-\end{array}$ & $\begin{array}{l}\text { MA } \\
\text { MR } \\
3 A_{4} \\
\text { MA } \\
11\end{array}$ & $\begin{array}{r}3 \\
2 \\
14 \\
0 \\
-\end{array}$ & 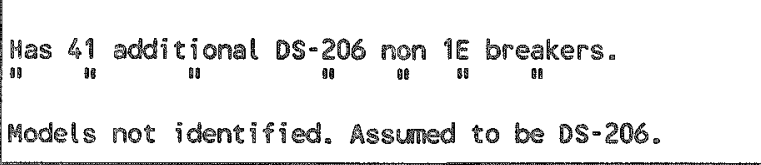 \\
\hline $\begin{array}{l}\text { Vogtle Unit } 1 \\
\text { Vogtle Unit? }\end{array}$ & $\begin{array}{l}0 \\
0\end{array}$ & 6 & MA & $\begin{array}{l}6 \\
4\end{array}$ & $\begin{array}{l}\text { MA } \\
\text { NA }\end{array}$ & $\begin{array}{l}5 \\
3\end{array}$ & $\begin{array}{l}\text { MA } \\
\text { MA }\end{array}$ & $\frac{N P}{3}$ & \\
\hline $\begin{array}{l}\text { WpPsS Unit } 2 \\
\text { Wolf creek }\end{array}$ & $\begin{array}{l}0 \\
0\end{array}$ & $\begin{array}{r}26 \\
5\end{array}$ & $\begin{array}{l}\text { NAA } \\
\text { MA }\end{array}$ & $\begin{array}{r}26 \\
0\end{array}$ & $\begin{array}{l}\text { NA } \\
\text { NA }\end{array}$ & $\begin{array}{r}8 \\
\text { NP }\end{array}$ & $\begin{array}{l}\text { MA } \\
\text { NAA }\end{array}$ & $\begin{array}{l}13 \\
\text { MP }\end{array}$ & Has 40 additional non IE breakers. \\
\hline $\begin{array}{l}\text { zion } \\
\text { zion } 2\end{array}$ & 35 & 2 & 35 & 2 & NR & NR & NR & MR & No information available. \\
\hline
\end{tabular}

Notes: NA $=$ Mot Applicable, NP $=$ Not Performed, NB $=$ Not Reported, RTBS = Reactor Trip Breakers 
Table 3.4 Responses of Utilities with DS Breakers for Class 1E Service (February 1989)

b. Long Term Inspection Results

\begin{tabular}{|c|c|c|c|c|c|c|c|c|c|}
\hline \multirow[b]{2}{*}{ Plant Mane } & \multicolumn{2}{|c|}{$\begin{array}{l}\text { Breakers } \\
\text { Inspected }\end{array}$} & \multicolumn{2}{|c|}{$\begin{array}{c}\text { Passed Criteria } \\
7.1\end{array}$} & \multicolumn{2}{|c|}{$\begin{array}{l}\text { Passed Align. } \\
\text { Check }\end{array}$} & \multicolumn{2}{|c|}{$\begin{array}{l}\text { Pole shafts } \\
\text { Replaged }\end{array}$} & \multirow{2}{*}{ Remarks } \\
\hline & $10 \$-206$ & $10 \$-416$ & $10 S-206$ & $0 S-416$ & $105-206$ & $\operatorname{los}-416$ & DS-206 & DS-4. 16 & \\
\hline $\begin{array}{l}\text { Beaver Valley Unit } 2 \\
\text { Braidwood Units } 1 \text { \& } 2 \\
\text { Byron Unirs i \& } 2\end{array}$ & $\begin{array}{l}\text { MA } \\
:\end{array}$ & $\begin{array}{l}2 \\
:\end{array}$ & HA & $\begin{array}{c}\text { NRR } \\
- \\
-\end{array}$ & $\begin{array}{c}\text { NA } \\
:-\end{array}$ & NR & MA & $\begin{array}{l}0 \\
- \\
=\end{array}$ & Ho information available. \\
\hline $\begin{array}{l}\text { Callaway Unit } 1 \\
\text { Calvert cliffs unit } 1 \\
\text { calvert cliffs unit } 2 \\
\text { Cacawba Units } 1 \& 2 \\
\text { Conanche Peak Units } 182\end{array}$ & $\begin{array}{l}\text { MA } \\
43 \\
44 \\
\text { MA } \\
\text { MA }\end{array}$ & $\begin{array}{r}8 \\
10 \\
10 \\
4 \\
?\end{array}$ & $\begin{array}{l}\text { NA } \\
15 \\
35 \\
\text { MA } \\
\text { MA }\end{array}$ & $\begin{array}{l}4 \\
2 \\
9 \\
3 \\
-\end{array}$ & $\begin{array}{l}\text { MA } \\
43 \\
42 \\
\text { MA } \\
\text { MA }\end{array}$ & $\begin{array}{r}4 \\
10 \\
10 \\
3 \\
-\end{array}$ & $\begin{array}{l}\text { MA } \\
\text { \&E } \\
\text { HA } \\
\text { HAA } \\
\text { NAA }\end{array}$ & $\begin{array}{r}3 \\
9 \\
\text { MA } \\
5 \\
0\end{array}$ & $\begin{array}{l}\text { Pole shafts remelded at the backside of the original welds. } \\
\text { Models mot identified. Assunned to be DS- } 416 \text {. } \\
\text { Inspections will be done prior to fuel load. }\end{array}$ \\
\hline $\begin{array}{l}\text { Farley Unit } 1 \\
\text { Farley Unic } 2\end{array}$ & $\begin{array}{l}58 \\
\mathrm{NA}\end{array}$ & $\begin{array}{r}13 \\
4\end{array}$ & $\begin{array}{l}\text { 1L } \\
\text { NA }\end{array}$ & $\begin{array}{l}8 \\
0\end{array}$ & 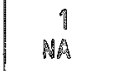 & $\begin{array}{r}0 \\
N P\end{array}$ & $\begin{array}{l}57 \\
\text { MA }\end{array}$ & 9 & $\begin{array}{l}\text { Unit } 2 \text { : only RT information available } \\
5 \text { shapts will be replaced when avallable. }\end{array}$ \\
\hline Harris Unit 1 & MA & RTBs & MA & ALL $(-1)$ & MA & ALL & MA & 1 & Breaker population not available \\
\hline Indian Point Unit 3 & 0 & 32 & MA & NP & MA & NP & 0 & 2 & \\
\hline $\begin{array}{l}\text { MeGuire Units } 1 \& 2 \\
\text { Millstone Uni } 3\end{array}$ & $\begin{array}{l}\text { MA } \\
\text { NA }\end{array}$ & 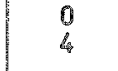 & NA & NPP & MPA & MP & $\begin{array}{r}\mathrm{NA} \\
0\end{array}$ & $\stackrel{8}{0}$ & \\
\hline $\begin{array}{l}\text { Palo Verde Unit } 1 \\
\text { Palo verde Unit } 2 \\
\text { Palo verde Unit } 3\end{array}$ & $\begin{array}{l}\text { MA } \\
\text { NA } \\
\text { PAA }\end{array}$ & $\begin{array}{l}2 \\
2 \\
2\end{array}$ & $\begin{array}{l}\text { MA } \\
\text { MA }\end{array}$ & $\begin{array}{l}2 \\
2 \\
2\end{array}$ & $\begin{array}{l}\text { NAA } \\
\text { MAA } \\
\text { NA }\end{array}$ & $\begin{array}{l}\text { NP } \\
\text { NPP }\end{array}$ & $\begin{array}{l}\text { HA } \\
\text { MA } \\
\text { MA }\end{array}$ & $\therefore$ & 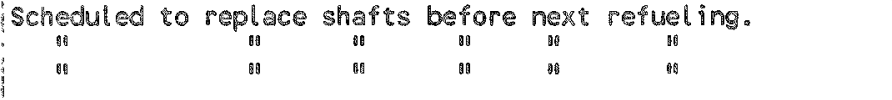 \\
\hline $\begin{array}{l}\text { Sea Brook Unit 1 } \\
\text { south Texas Unit } 1 \\
\text { South Texas Unit } 2 \\
\text { Summer Unit } 1 \\
\text { Sequoyah Unit }\end{array}$ & $\begin{array}{l}\text { HA } \\
\text { MR } \\
35 \\
\text { MA } \\
15\end{array}$ & $\begin{array}{r}5 \\
4 \\
17 \\
5 \\
\end{array}$ & $\begin{array}{l}\text { MA } \\
\text { NR } \\
35 \\
\text { NA } \\
\text { NP }\end{array}$ & $\begin{array}{r}1 \\
2 \\
17 \\
5 \\
-\end{array}$ & $\begin{array}{l}\text { NA } \\
\text { NR } \\
35 \\
\text { NA } \\
\text { NP }\end{array}$ & $\begin{array}{r}5 \\
4 \\
17 \\
5 \\
-\end{array}$ & $\begin{array}{l}\text { MA } \\
\text { MR } \\
34 \\
\text { MA } \\
4\end{array}$ & $\begin{array}{r}5 \\
14 \\
14 \\
5 \\
-\end{array}$ & $\begin{array}{l}\text { Has } 41 \text { additional OS-206 non } 1 \text { IE breakers. } \\
\text { Models not identified. Assuned to be DS-206. }\end{array}$ \\
\hline $\begin{array}{l}\text { Vogtle Unit } 1 \\
\text { Vogtle Unit } 2\end{array}$ & $\begin{array}{l}\text { NA } \\
\text { NA }\end{array}$ & $\begin{array}{l}6 \\
4\end{array}$ & $\begin{array}{l}\text { NA } \\
\text { NA }\end{array}$ & $\begin{array}{r}\text { MP } \\
3\end{array}$ & $\begin{array}{l}\text { NAA } \\
\text { NA }\end{array}$ & $\begin{array}{l}\text { NP } \\
4\end{array}$ & $\begin{array}{l}\text { NA } \\
\text { NA }\end{array}$ & $\begin{array}{l}1 \\
1\end{array}$ & \\
\hline $\begin{array}{l}\text { WPPSS Unit } 2 \\
\text { Holf Creek }\end{array}$ & $\begin{array}{l}\text { MA } \\
\text { NA }\end{array}$ & $\begin{array}{r}26 \\
0\end{array}$ & $\begin{array}{l}\text { MA } \\
\text { NA }\end{array}$ & $\begin{array}{l}16 \\
\text { NP }\end{array}$ & $\begin{array}{l}\text { MAA } \\
\text { NA }\end{array}$ & $\begin{array}{l}25 \\
\text { NP }\end{array}$ & $\begin{array}{l}\text { NA } \\
\text { NA }\end{array}$ & $\begin{array}{l}5 \\
5\end{array}$ & Has 40 additional non ie breakers. \\
\hline $\begin{array}{l}\text { zion } 1 \\
z \text { ion } 2\end{array}$ & 35 & 2 & NR & NR & 35 & 2 & 29 & 2 & No information available. \\
\hline
\end{tabular}

Notes: NA $=$ Not Applicable, NP $=$ Not Performed, NR $=$ Not Reported, RTBs = Reactor Trip Breakers 
Many of the substandard welds between the pole shaft and the pole levers were reported to be less than $180^{\circ}$ in length and less than $3 / 16$ inch fillet size. Instead of a single pass fusion over the entire length, many welds consisted of multiple passes and fusion was not effective between two adjacent passes, specifically at both ends of the weldment. In some cases, porosity was noticed in between two weld passes, as well as at two ends of the weld. A very small number of welds had hair-1ine cracks in the welds. Careful inspection of the weld fusion on the parent material revealed evidence of cold work and substandard welding techniques.

The utilities have expressed difficulties in performing the recommended short-term and long-term inspections without taking the breaker out of the cell. Removing the front plate alone did not give adequate accessibility to examine the welds properly, specifically, the centerpole lever weld which is located behind the close cam assembly. Boroscopes and dental mirrors sometimes were used to detect cracks in these lever welds. Therefore, many utilities performed their inspections during breaker maintenance, and some developed a program plan to make short-and long-term inspections together. Several utilities have not completed their long-term inspections, and plan to do so by their next scheduled plant outage on refueling.

As a result of the inspections, a large number of pole shafts were replaced or are being considered for replacement. Some licensees had also considered replacing the entire breaker with new units; a few had chosen to re-weld the levers to the shaft before returning the breakers into operation. A check of pole shafts and the main roller drive link showed that misalignment of breaker pole assembly was not a problem. However, technical experts in the plants agree that poor welds in the pole shaft can alter the alignment of the pole and, hence, can be detrimental to the breaker operation.

An overal1 assessment of breaker aging indicated that units which experience a large number of operating and/or maintenance cycles exhibit more failures than those less frequently used. While the reactor trip breakers are required to be periodically cycled for technical specification requirements, and are subjected to more frequent maintenance cycles, the breakers on the charging pump and instrument air compressor motors often experience a large number of cycles because of their frequent operation during the normal plant operation. Thus, breakers associated with reactor trips, air compressors, and charging pump motors typically experience 200-300 cycles each year of plant operation, and thus have early signs of age-related degradation.

\subsection{Discussion}

Our evaluation of utilities' response to NRC Bulletin 88-01 generated the following conclusions:

- Substandard welds in the pole shafts were evident from the inspections. The probable cause was that they were manufactured as commercial-grade components and the earlier dedication program for class $1 E$ application presumably lacked the quality assurance (QA) needed for nuclear service. 
- Typical causes of substandard welds as revealed through inspection programs recommended in the bulletin are:

- inadequate weld size ( $<3 / 16$ inch fillet)

- smaller weld length $\left(<180^{\circ}\right)$

- multiple pass weld (not continuous one-pass weld)with flaws between passes

- improper fusion between the weld metal and the parent metal (existence of cold work, porosity, cleavages)

- sloppy workmanship

- The new pole shafts which replaced the older units were good and passed the inspection criteria. Thus, replacing pole shafts might eliminate the weld problems experienced by the breaker operation.

- It was difficult to perform both inspections properly without disassembling the breaker. Therefore, many utilities prepared to perform their long-and short-term inspections while the breaker was taken out for maintenance.

- Breakers subjected to many operating and/or maintenance cycles are susceptible to early weld failures. Hence, it is suggested that whether Class $1 \mathrm{E}$ or non-Class $1 \mathrm{E}$ each breaker designed for a large number of mechanical cycles should undergo more frequent inspections to assure its reliable operation.

- Plants with a large population of DS-breakers should consider an inspection and/or maintenance program to periodically evaluate their performances as they age with the operating cycles. 


\section{OPERATING EXPERIENCE DATA ANALYSIS}

Low-voltage power circuit breakers are widely used in nuclear power plants for safety- and non-safety functions. A typical plant may contain about 50 such units in Class $1 \mathrm{E}$ application, and the same or more for non-class $1 \mathrm{E}$ use. As discussed earlier, one important application is as reactor trip breakers in PWR Reactor Protection systems. Since this class of breaker is also used in metalenclosed switchgears to control and protect power circuits up to 600 volts, they are important in the power circuits of motor-driven equipment such as pumps, motor-operated valves, cranes, and other intermediate-size equipment.

It is evident from the issuance of the large number of NRC information notices, bulletins, and generic letters on circuit breaker-related problems (see Appendix A) that the breakers have experienced a variety of problems associated with their subcomponents during the last 15 years. The subcomponents include products from the three prime manufacturers of these breakers; Westinghouse, General Electric, and Brown Boveri Company. Although these identified problems are predominantly associated with reactor trip breakers, the same symptoms were also observed in breakers used for other Class IE and non-safety applications. Typical problems include linkage sticking, failures of UVTA or shunt coil, inability to close or trip, switch malfunctions, loose mounting bolts, mechanical binding of spring release devices, coordination of relays and circuit breakers, and defects in center-pole welds.

In addition to these problems, our study focuses on determining the root causes of premature fracture of welds connecting the center pole levers with the pole shaft in the Westinghouse DS-206 and DS-416 circuit breakers. The problem was originally discovered when the $2 B$ reactor trip breaker (RTB) at the McGuire Unit 2 plant failed to open on electrical command on July 2, 1987 . It had jammed mechanically. The next day, Duke Power observed a second jamming of the RTB while investigating the cause of the first failure. However, the RTBs were fixed before the cause of the jamming was determined. Further investigations by the NRC Augmented Inspection Team and the Nuclear Services Integration Division (NSID)* of Westinghouse revealed that the weld between the center pole lever and the pole shaft of the RTB had completely separated. It was believed that the weld separation might have caused the jamming of the RTB.

A similar incident occurred at Calvert Cliffs $^{9}$ where weld failures in the pole shaft for the Westinghouse DS-series breakers resulted in burning out of electrical control devices. The reported event was investigated a year before to the McGuire event, and the examination of the separated surface revealed that approximately 70 percent of the weld had not been fused to the lever arm. This 30 percent represented the areas that fractured during operation of the breaker. Unlike the McGuire RTB event, this failure occurred in one of the charging pump breakers whose mode of operation was closing (rather than tripping) the breaker. Investigators concluded that lack of fusion of the weld was the root cause of the breaker failure.

* Currently, the Nuclear Service Division (NSD). 
On September 23, 1987, Westinghouse presented their evaluation to the NRC ${ }^{2}$, providing the following information:

1) Based on calculations and tests, Westinghouse stated that even $10 \%$ of the design weld length would carry the actuation load, and fatigue failure would not occur.

2) There was no evidence of pole shaft failure after performing over 90,000 breaker test operations. The highest number of operations on a given breaker was 10,964 .

3) The breakers are manufactured as a commercial-grade device and subsequently dedicated for use in a safety-related application.

In addition, Westinghouse representatives presented a strategy for visually inspecting the failed welds, and discussed the quality assurance (QA) process used during the breaker manufacturing. One of the remaining NRC concerns was that the Westinghouse calculations of stress were based on static rather than dynamic factors for the welds.

Under contract to the NRC, the Franklin Research Center (FRC) examined the failed weld at the McGuire, and also evaluated the Westinghouse position on the breaker failure. ${ }^{3}$ They performed a very detailed metallurgical investigation of the weld surfaces, and concluded that the weld failure was primarily due to substandard welds which were subjected to many operating cycles. They expressed concerns related to the Westinghouse tests and calculations on the subject of qualifying the life of the breakers. The FRC strongly recommended a periodic visual inspection to determine the state of the welds.

\subsection{Analysis of Previous Operating History}

After the McGuire event, the NRC office for Analysis and Evaluation of Operational Data (AEOD) performed a search for operating experience in the NPRDS specific to DS-416 RTBs, and found no significant results relating to the weld failures in this breaker ${ }^{10}$. Reference 1 describes a review of the operating history of circuit breakers and relays, made as part of a Phase 1 study for the NPAR program. This study included a tabulation of failure events for the 58 DS series breakers that were identified in NPRDS. These events are summarized by circuit breakers subsystem and frequency of occurrence in Table 4.1.

Table 4.1. DS Circuit Breaker Failures

Subsystem

Main Power Path

Electrical Control

Mechanism

Racking system

Miscellaneous
Percentage Failures

5

64

21

7

3 
This information shows that subsystems involved with the electrical control of the breakers, including switch contacts, coils, and overcurrent trip devices, were the dominant contributors to breaker failures. Pole shaft failures were not explicitly identified in the results. However, similar to the AEOD findings, these results are insufficient to conclude that there were no weld failures on the pole shaft since the NPRDS descriptions do not always identify the root cause of a failure. For example, coils were identified in approximately 228 of the fallures; however, the root cause of the coil failures was not always identified. Thus, an unidentified failure may have been responsible for overheating due to jammed mechanisms, and subsequent failure of the coils.

\subsection{Analysis of Current Operating History}

Since our research objective was the performance of the DS-series breakers, an independent review of the operating data for these breakers was performed. This review included the failure events described in NPRDS, Licensee Event Reports (LERs), and Nuclear Power Experience (NPE). The primary source of information for this study was NPRDS; this data was analyzed following the NPAR strategy and the results are described in the following sections.

\subsubsection{Analysis of NPRDS Data}

NPRDS provided 107 failure events associated with DS-206 and DS-416 breakers as of June 1988; 90 events were associated with DS-206, and 17 with DS-416. This difference reflects the larger population of the DS-206 breaker, as was evident from the licensee responses (Section 3). Each description of failure was reviewed to determine the mode and the cause of failure, and the subcomponent that failed. Table 4.2 summarizes the various subcomponents that contributed to a breaker failure.

Table 4.2. DS Breaker Subcomponent Failures - NPRDS

Subcomponent

Coil

Contacts

Charging Motor Switch

Charging System-Mechanical

Amptector

Trip Mechanism

Wiring

Charging Motor

Closing Mechanism

Fuse and Fuse Holder

others
Percent of Failures

19

14

13

13

6

6

5

5

4

3

12 
The results in this table show that subcomponents in the electrical control system (i.e., coils, contacts and switches) contribute to $46 \%$ of the failures in the circuit breaker. It is interesting to note that three failures involved the failure of welds: two events were the result of inspections in response to Bulletin 88-01 and identified pole shafts that did not meet the NRC weld inspection criteria; the third failure involved a broken weld on the upper contact support plate. These two pole-shaft weld failures represent only a small fraction of the inadequate welds that were reported to the NRC in the responses to Bulletin 88-01. Our subsequent search of NPRDS data identified more DS breaker failures that were discovered during the inspection prescribed by Bulletin $88-01$.

The mode of failure for each of these circuit breaker events was analyzed (Figure 4.1). This figure shows that the failure of the breaker to close on demand is the dominant failure mode, contributing to more than $50 \%$ of the failures. The remaining modes all contribute a low ( 88 to $11 \%$ ) number of the reported failures.

The NPRDS information also was analyzed to rank, in importance, the various causes of the DS breaker failures. For this analysis, a cause of failure was considered to be the actual malfunction that led to the breaker's degradation or failure. The review showed that the causes of failure in these 107 events was dominated (228) by the accumulation or deposition of foreign material on various breaker subcomponents (Figure 4.2). As noted in Table 4.2, contacts and charging motor switches were failed in 27\% of the NPRDS events; this result, combined with the dominant failure cause suggests that the most frequent scenario is the failure of switches and contacts caused by the buildup of dirt, grease, or other foreign material. other important causes of failure include normal operation (wear), overheating, and improper adjustment. The importance of overheating as a cause ( 148 of the failures) is substantiated by the identification of coils as the dominant failed subcomponent.

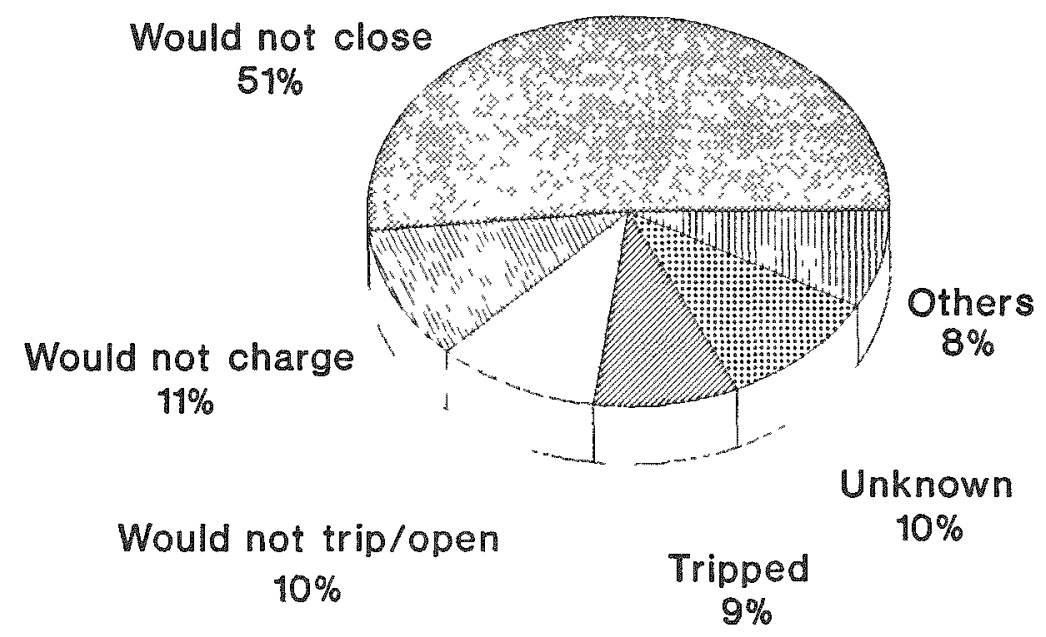

Figure 4.1 DS Breaker Failure Modes - NPRDS

$$
4-4
$$




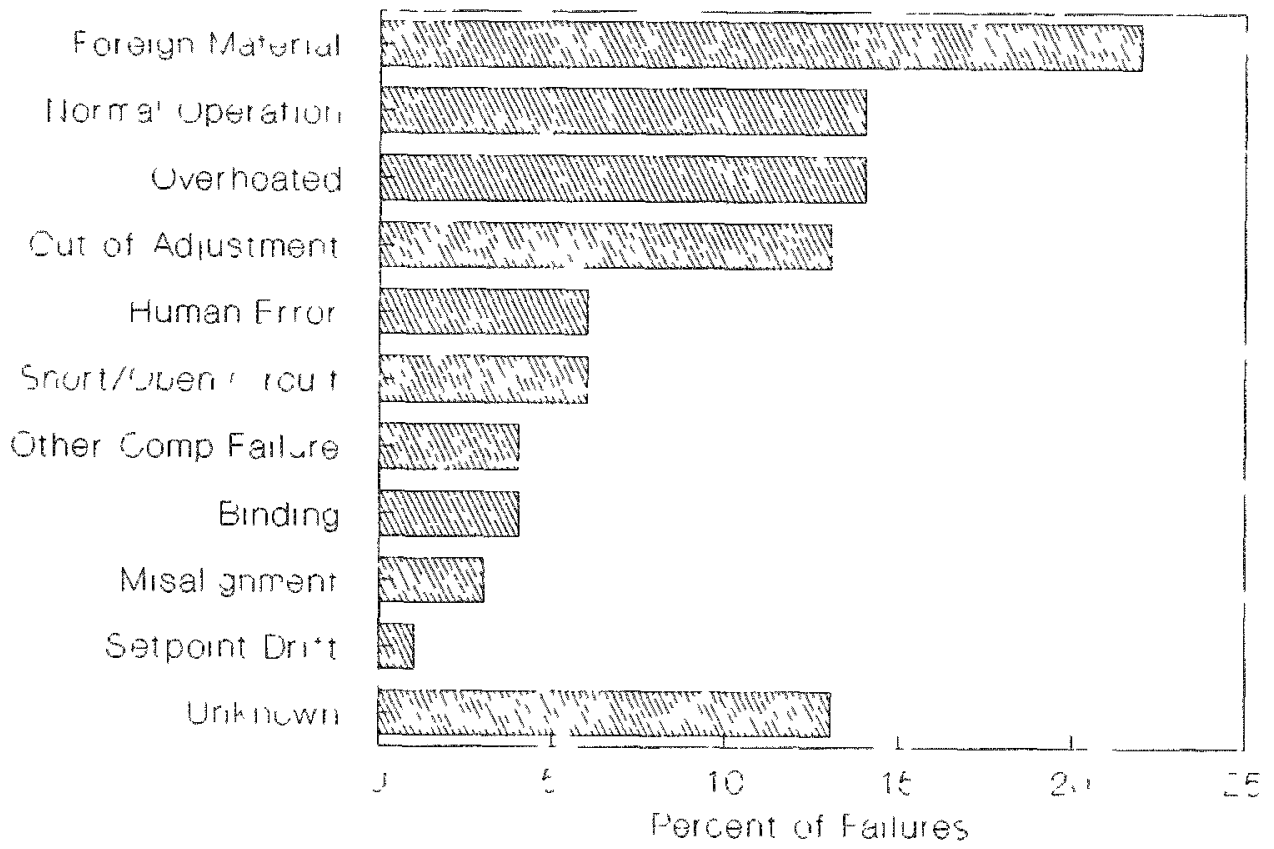

Figure 4.2 Failure Cause

Additional insight into the relationship between the failed subcomponents and causes of failure was obtained by analyzing the causes associated each subcomponent. In Table 4.3, the four most important subcomponents are listed with the various causes of failure. The results clearly indicate the association of overheating with coils and the accumulation of foreign material with contacts and switches.

The percentages shown in Table 4.3 are normalized to 100 for each subcomponent. However, the percentages do not total 100 due to other, causes and unidentified causes. In addition, the category of human error includes failures due to errors in installation and maintenance. However, human errors may not constitute a significant contribution to DS breaker failures. 


\section{Table 4.3 Summary of Failure Causes for Circuit Breaker}

\section{Subcomponents}

$\begin{array}{llc}\text { Subcomponent } & \text { Failure Cause } & \text { Percent of Failures } \\ \text { Coils } & \text { Overheating } & 65 \\ & \text { Short/Open Circuit } & 15 \\ \text { Contacts } & \text { Foreign Material } & 53 \\ & \text { Human Error } & 20 \\ \text { Charging Motor } & \text { Foreign Material } & 79 \\ & \text { Switch Out of Adjustment } & 13 \\ & \text { Normal Operation } & 8 \\ \text { Charging System } & \text { Normal Operation } & 50 \\ \text { Mechanical } & \text { Out of Adjustment } & 21 \\ & \text { Binding } & 6 \\ & \text { Human Error } & 6\end{array}$

The NPRDS data was also analyzed for the age of the circuit breakers at the time of failure, the system effected by the breaker failure, and the operating status of system including the breaker at the time when the failure was detected. These results are discussed in the following paragraphs.

1. Age of the Circuit Breaker: We determined the breaker's age at the time of failure (as measured from the date of initial criticality) for each event. The ages were then grouped into 5-year time periods, as shown in Figure 4.3. The figure shows there is an increase in the number of failures in the 6-10 year age group that corresponds to the results described in Reference 1. However, the total number of failures is small and any further interpretations would not be meaningful.

2. System Effected by Breaker Failure: The NPRDS information identifies the system that is most directly affected by the breaker failures. As shown in the Figure 4.4, more than $60 \%$ of the failures affected the chemical and volume control and containment cooling systems. These systems include a large number of motor operated valves, pumps, and fans suggesting that the breakers were used to control and protect the associated motors.

3. System Operating Status: The analysis of the operating status of the system at the time the breaker failure was detected is summarized in Figure 4.5 . These results indicate that only a small percentage of the failures (27\%) were identified during surveillance and maintenance and suggest that modifications to the frequency and implementation of these procedures could improve the reliability of the effected systems. 


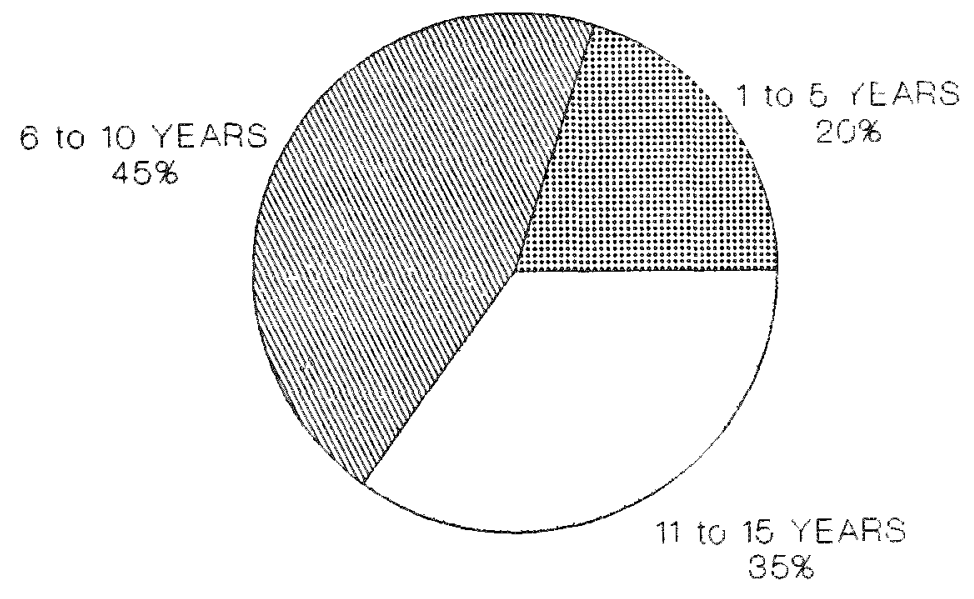

Figure 4.3 DS Failures with Age

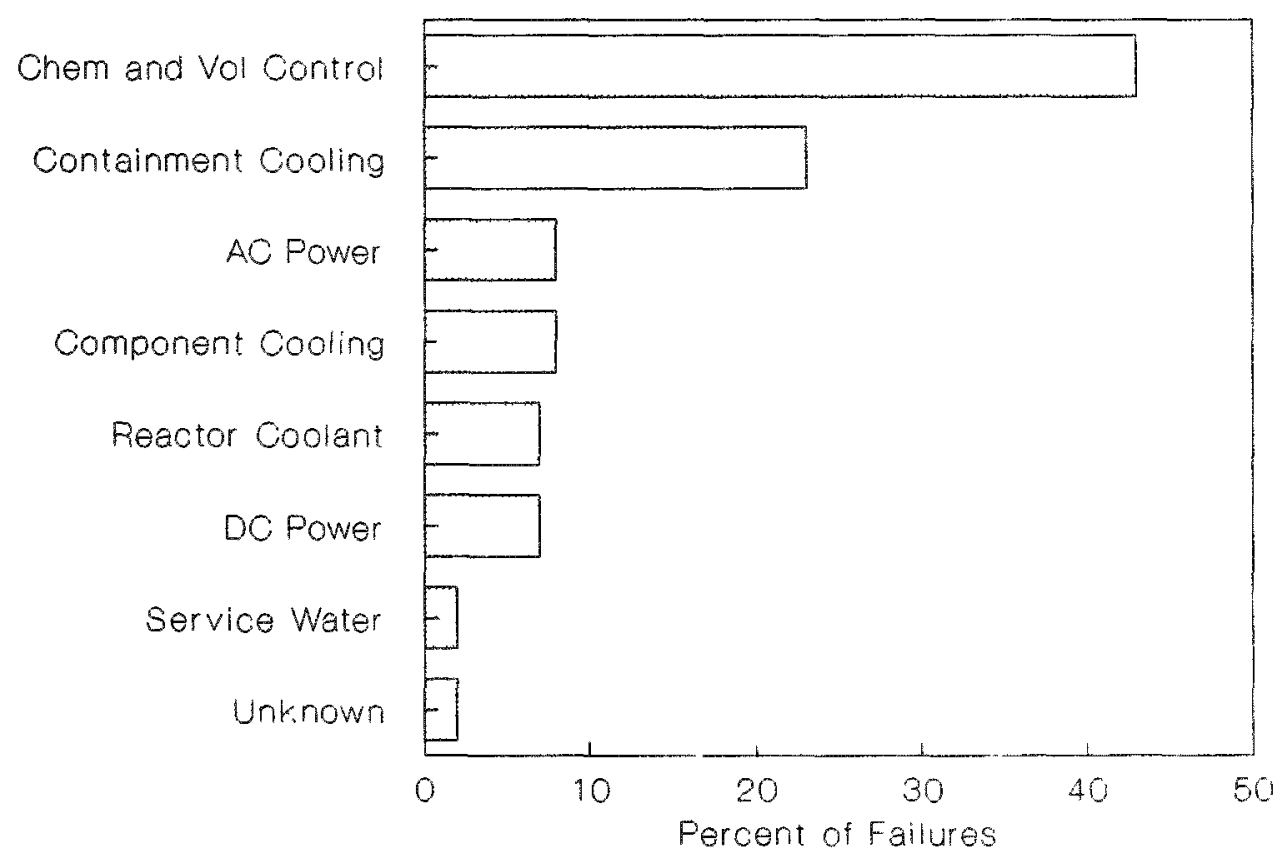

Figure 4.4 Systems Affected

$4 \cdot 7$ 


\subsubsection{Review of Nuclear Power Experience}

A review of 138 failure reports related to circuit breakers described in NPE produced only 6 that were related to DS breakers. (Several of these reports included multiple circuit-breaker failures.) In many cases, the specific model numbers of the breakers were not included in the descriptions and thus, were not included in this analysis. Typical failure modes and causes that were described included:

- Faulty control wire insulation (later corrected by a Westinghouse design change)

- Corrosion of the trip actuator mechanism caused by inadequate cleaning during assembly

- Under-voltage trip device failure related to the mechanical mechanism

- Overheated under-voltage coil

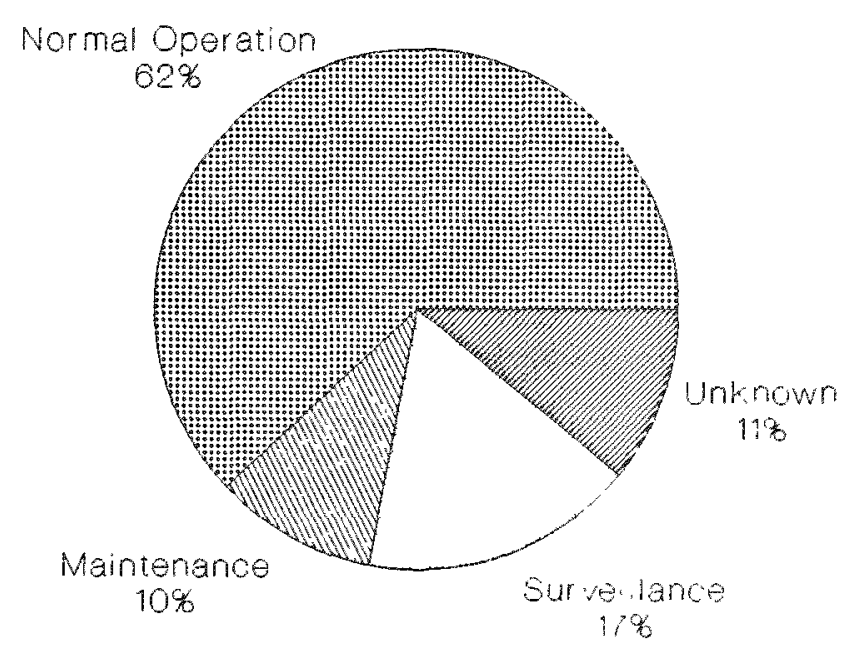

Figure 4.5 System Operating Status when DS Breaker Failure Occurred

$$
\text { 4-8 }
$$




\subsection{Sumary of Results}

The number of reported failures relating to DS-series breakers in nuclear power plants in any of the national data bases (i.e., NPRDS, LER, NPE) is 1imited. However, there are certain trends in the failure modes of breaker subcomponents which are age-related. The root cause of these modes are difficult to ascertain, because of the paucity of data and lack of specificity in the event reports. Some of these results from this analysis are summarized below:

- A large percentage of breaker failures is due to electrical control problems involving switch contacts, coils, and overcurrent trip devices. Next are problems in the operating mechanism problems which include those mechanical components used for tripping or closing the breaker.

- Since a large population of breakers are used to close the circuits compared to that of RTBs which are set for tripping under normal conditions, the predominant failure mode relates to closing the breaker.

- The accumulation of foreign materials such as dust and water dominates categories of cause for breaker failures. Additionally, normal wear, overheating, and out-of-adjustment control parameters are equally responsible for many breaker problems.

- Aging of the subcomponents of breakers is evident from the data on operating experience. Burning of coils, deterioration of main and auxiliaxy contacts, charging motor failure, and binding of linkages exhibited the most failures under normal operating conditions.

- Breakers in nuclear systems that are subjected to more frequent cycles (on/off) are susceptible to premature failures. Hence, in the chemical volume and control system, the charging pump breakers fail more often than other standby or continuously operating systems. 
Industrial experience with the DS-series breaker was received from nuclear and non-nuclear affiliated organizations. Westinghouse, the manufacturex of these breakers, was solicited for information. One company, involved in repairing and refurbishing all types of nuclear and non-nuclear breakers, also provided input. Another company providing service to the telephone industry was questioned about the performance of these breakers. Finally, from the utilities' responses to NRC Bulletin 88-01, it was established that certain plants have an extensive use of these breakers. A utility was visited to evaluate their experience on the breakers' overall performance.

This study focussed on problems with all DS-series breakers, in particular, the DS-206 and DS-416 mode1s. This section discusses background in the nuclear industry experience, and results from the perspective of other industries.

\subsection{Pre-Salem RTB Event}

Historically, most breaker problems reported by the nuclear industry were for the reactor trip application because of their safety importance. The breaker type that preceded the DS-416 breaker was the Westinghouse DB-50, type A air circuit breaker. In the event of a reactor trip, signals are automatical. ly sent from the reactor trip logic to the tripping devices on the DB-50 or DS416 reactor trip breakers. As discussed earlier, the design of the reactor trip switchgear has a bypass breaker associated with each of the two RTBs in series to give redundancy to the system. The undervoltage trip attachment (UVTA) opens the breaker on demand. Below is the chronological order of all the events in nuclear power plants ${ }^{11}$ that were associated with problems in RTBs:

1971 Robinson-2 and Connecticut Yankee had similar problems in their UVTA devices. The relays did not have sufficient force to lift the trip bar, and thereby failed to trip the scram breakers. The cause was considerable friction between the trip lever and the relay housing due to a combination of surface contamination and rough surfaces.

- Westinghouse issued a Service Information Report describing modifications to UV devices during 1971 and 1972.

1973 - The problem resurfaced again in December at Robinson-2 and it was determined that a sma11 amount of friction in the UV mechanism could reduce the force of the trip finger enough to prevent the trip bar from being moved.

- Westinghouse issued a Technical Bulletin recommending regularly scheduled inspections/maintenances for reactor trip breakers (DB50). These measures were to be carried out in conjunction with periodic operational testing of the breakers or tests during plant shutdowns. It was recommended that maintenance be performed on a 
semi-annual to yearly basis, depending on the operating and environmental conditions. The maintenance included blowing with dry instrument air, followed by vacuum cleaning, and lubricating the linkage of the UV device sparingly with Molykote M-88 or Spraykote.

1976 - Zion-1 train "B" breaker failed to trip during a test in September due to dirt. After a thorough cleaning, the breaker operated properly.

- Point Beach 1 train "A" breaker also failed to trip during a test in November and the UV device was found to be sticking.

1977 - Zion 2 train "A" breaker failed to trip during a test in March; the cause was never determined.

- Zion 1 train "B" breaker failed to trip in May following a turbine trip. The relay was replaced and it was decided that the UVTA could have been the cause for both the September 1976 and this failure.

1978 - Kewaunee had a tripping problem during a test in December and, as a result, the preventive maintenance program was revised to include routine inspection for cleanliness and proper lubrication.

1979 - A similar event occurred again at Zion 2 in October following a reactor trip. The maintenance program was revised to include lubricating the breaker.

1982 - North Anna 1 discovered similar problems during a test in November and similar action was taken to correct the problem.

In addition to the sticking, cleaning, and lubrication problems associated with DB-50 breakers, other failure modes were observed at Salem in 1983.

\subsection{Salem RTB Failures: NRC Generic Letter 83-28}

On January 6, 1983, Salem-2 experienced a trip from 46\% power because of low steam generator level. The RTB "A" did not function, while RTB "B" performed the reactor shutdown. About 25 minutes later, an operator observed that breaker "A" tripped with no operator action. Malfunction of the UVTA relay was the cause. At that time, the breakers were being inspected during each refueling outage.

On February 22, 1983 the automatic scram at Salem-1, due to steam generator low level, was stalled by two faulty DB-50 breakers and manual scram was initiated by an operator. Three days later on February 25, 1983, Salem-1 experienced another trip on low steam generator level and the reactor was at $12 \%$ power. Because of the faulty breakers the reactor was tripped manually from the control room about 30 seconds after the auto trip signal was generated. The failure to trip was attributed to sticking of the UVTA. 
Salem-2 train "B" breaker had earlier experienced some indications of breaker problems during surveillance testing on August 20,1982. Based on past history, sticking of linkages in the UVTA was the cause of breaker tripping problems. Other component problems identified in earlier breaker failures were a broken latch pin, presence of a rough edge or burx on the trip lever that was scoring the side of the UVTA causing friction, excessive spring pressure on the trip latch preventing the operation of the trip lever, and dust, contamination and adjustment changes in the trip mechanisms. Another possible cause was damage to the latch guide pin which might have led to a broken guide pin.

Following the Salem incidents, a number of IE Bulletins, Information Notices and Generic letters were issued during 1983-1987 by NRC (summarized in Appendix A). These documents addressed Westinghouse DB-50 breakers, but also included DB-25, DS-416, and General Electric AK-2 breakers. Examples of the causes identified for trip failures included:

- Improper lubrication of linkage and other moving parts within either the UVTA ox the breaker trip-bar latch assembly;

- inadequate adjustment of spring tension of the UVTA;

- excessive torque required to trip the breaker because of hardening and contamination of the grease in the trip shaft bearings; and

- excessive wear of moving parts within either the UVTA or the trip bar latch assembly because of infrequent lubrication of these moving parts or improper adjustments of the spring tension of the UVTA.

As a result of the Salem anticipated transient without scram (ATWS) events, NRC Generic Letter 83-28 required responses by the utilities. The four areas covered by this letter were:

1. Post Trip Review - requires a full understanding before plant restart of the causes for unscheduled reactor shutdowns, as well as the response of safety-related equipment.

2. Equipment Classification and Vendor Interface - requires documentation of all components necessary for accomplishing required safety related functions, and procurement of vendor information for safetyrelated components.

3. Post-Maintenance Testing - requires testing after maintenance of the operability of safety-related components.

4. Improvements in Reactor Trip System Reliability - requires that there is a comprehensive program of preventive maintenance and surveillance testing for the reactor trip breakers in PWRs, that the shunt trip attachment (STA) activates automatically in all PWRs that use circuit breakers in their reactor trip system, and that on-line functional testing of the reactor trip system be performed on all LWRs . 


\subsection{Westinghouse Perspectives}

Appendix A lists the NRC (or IE) bulletins, information notices, and generic letters relating to Westinghouse and other circuit breakers issued during the past several years. It was concluded that many of the failures appear partly to be related to deficiencies in the manufacturing process for circuit breakers. The lack of effective quality assurance, inadequate dedication procedure, improper fabrication, and inadequate recommendations for maintenance are the source of most breaker problems. In response to this, Westinghouse gave a general opinion that most of the problems cited in the NRC documents were random ones, and needed no action on Westinghouse's part except to improve their dedication program. ${ }^{12}$

Westinghouse assures that a "commercially" procured part is suitable for safety-related applications based on their thorough understanding of part/assembly operation and the effects of adverse operating conditions. The commercial circuit breakers (DS-206 and DS-416) are designed according to ANSI C37 and UL 1066 Standards. Each lot is sampled to provide 95\% confidence that the critical characteristics meet specifications. Each breaker is made with the high qual. ity standards of the westinghouse manufacturing process, and tested in accordance with ANSI C37.50 and life testing. According to their experience, the frequency of total incidents, including installation, startup, and initial adjustment is less than 0.58 . The breaker dedication process examines its critical functions such as opening on demand, closing on demand, and fault protection, and providing status contacts for indication, permissives, and interlocks. Westinghouse feels that their dedication program is adequate. However, based on the current feedback from vendor/customer experience, they are revising their program to improve quality. below: 12

Westinghouse's responses to specific breaker problems are discussed

- Insufficient margin in the lifting (trip) force provided to UVTA to move the breaker trip bar (DB-50) was attributed by inadequate lubrication and maintenance.

- The two weld failures in the secondary contact bracket constituted a manufacturing problem in a particular batch.

- Broken welds and non-uniform surface in closing-cam segments, and improper weld techniques and excessive misalignment of the main roller on the closed cam have caused only one operation failure. (e.g. . McGuire - 1987).

- Broken spring-release latch-levers have not affected any Class 1E breakers and were considered manufacturing problem in a particular batch.

- One broken pivot-pin to the trip latch due to improper brazing was considered as a random manufacturing problem. 
- Insufficient clearances between the breaker's moving parts, and the breaker's casing were due to four misshapen moving armature levers, and were considered a random manufacturing problem. Westinghouse is now gathering more data to determine the cause.

- Loss of spring tension due to deformation of the spring retainer in the cell-switch spring-return mechanism ( $W-2$ type switches) was due to aging of the spring retainer.

In conclusion, Westinghouse feels that none of the breaker manufacturing problems are generic. Improved maintenance and inspection programs can alleviate aging problems of breaker components.

\subsection{Breaker Service Industry (Other Than Westinghouse)}

We visited two breaker service companies to discuss their experience with DS-series breakers. One of them refurbishes breakers for both nuclear and nonnuclear industry, and the other maintains non-nuclear breakers. Five areas were discussed with cognizant technicians; their views follow:

- Design - The Westinghouse design of the pole shaft, although more than adequate for normal applications, seems less robust than those of the General Electric (GE) and Brown Boveri Company (BBC). The Westinghouse shaft is round, whereas it is hexagonal for $G E$ and square for $B B C$. Both $G E$ and $B B C$ include pole levers with flanges on the shaft so that even if a weld or soldering fails, the shape of the shaft keeps these levers in position.

- Manufacturing - The welding of pole levers to the shaft is inconsis tent. These inconsistencies are evident from Figures 5-1 (a-g) which illustrate each of seven welds of a shaft acquired by BNL.

- Operating - Non-nuclear application of these breakers may not require frequent cycling; once they are engaged, these breakers remain in that state for long periods. However, in safety application in nuclear power plant, specifically for reactor trips, the technical specification requirements may have contributed to frequent cycling causing fatigue or excessive force on these welds, which lead to premature cracks and, hence, failures.

- Maintenance/Refurbishment - The operating experience both in nuclear and non-nuclear areas reported by the maintenance groups, as well as repair shops, does not suggest that weld failures in the pole shaft associated with Westinghouse DS-breakers has been an industrywide problem. Problems with shunt trip coil burning, charging motor malfunction, and other contacts are more predominant. However, the weld failure can cause a high current flow in the shunt coils for longer than the rated value, which is typically a very short duration; this may cause burning of these coils. 


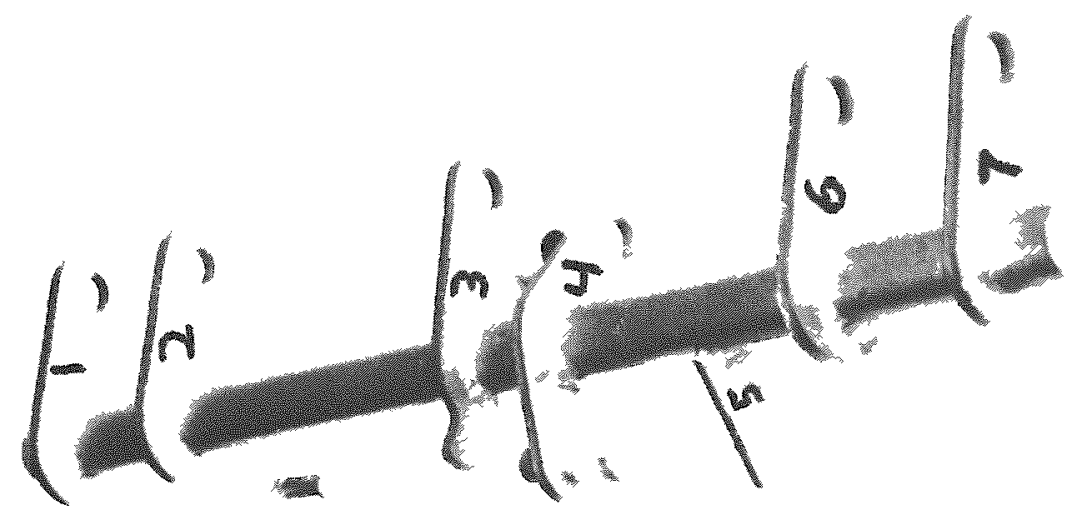

Figure 5-1 Pole Shaft with Levers (a-g)

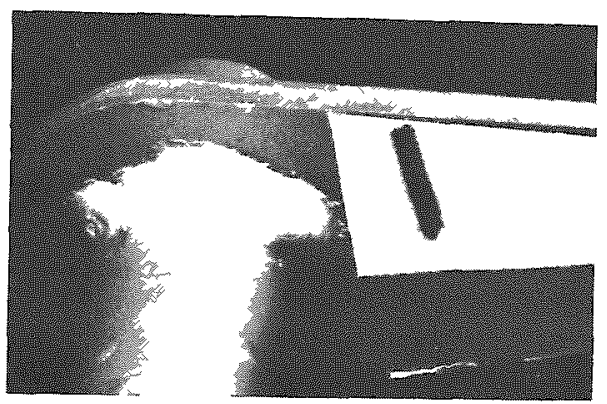

(a) Stop Lever (Left) Weld

(b) Left Pole Lever Weld

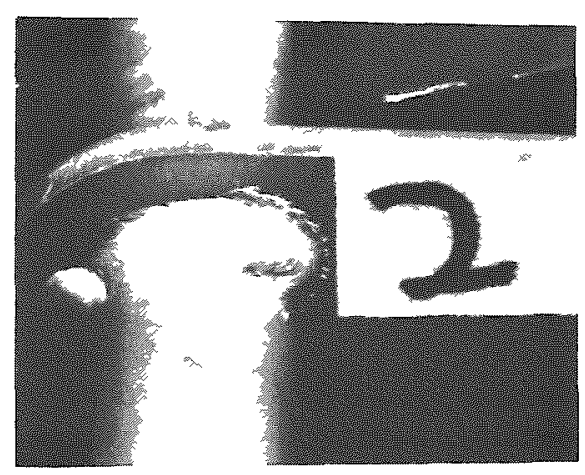

$5-6$ 


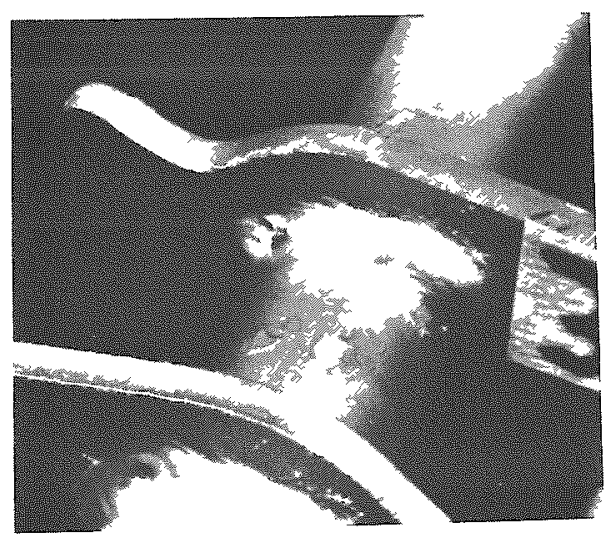

(c1) Center Pole Lever Weld

(c2) Center Pole Lever Weld
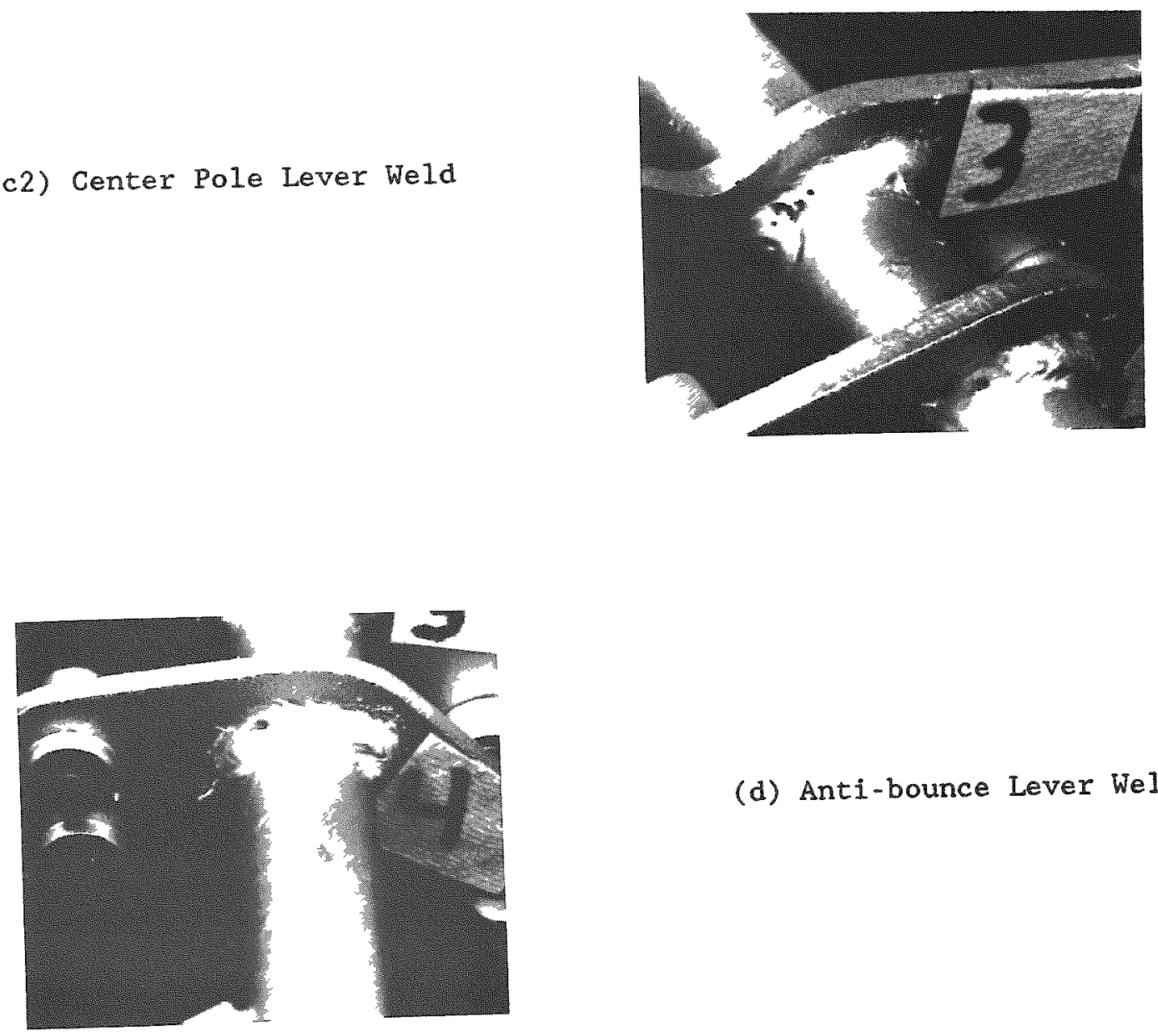

(d) Anti-bounce Lever Weld 


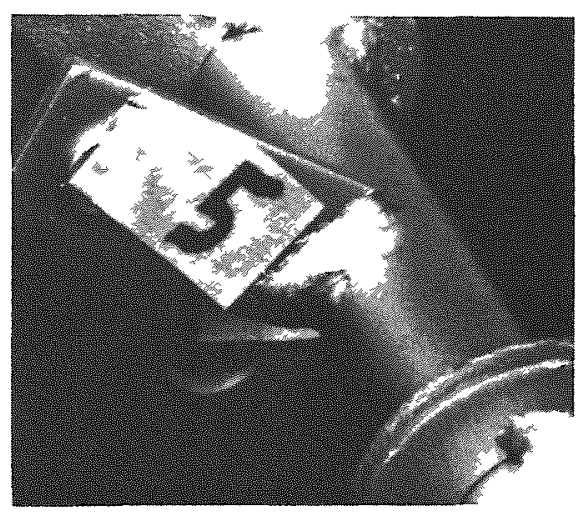

(e) Auxiliary Switch Drive Link Lever Weld

(f) Right Pole Lever Weld
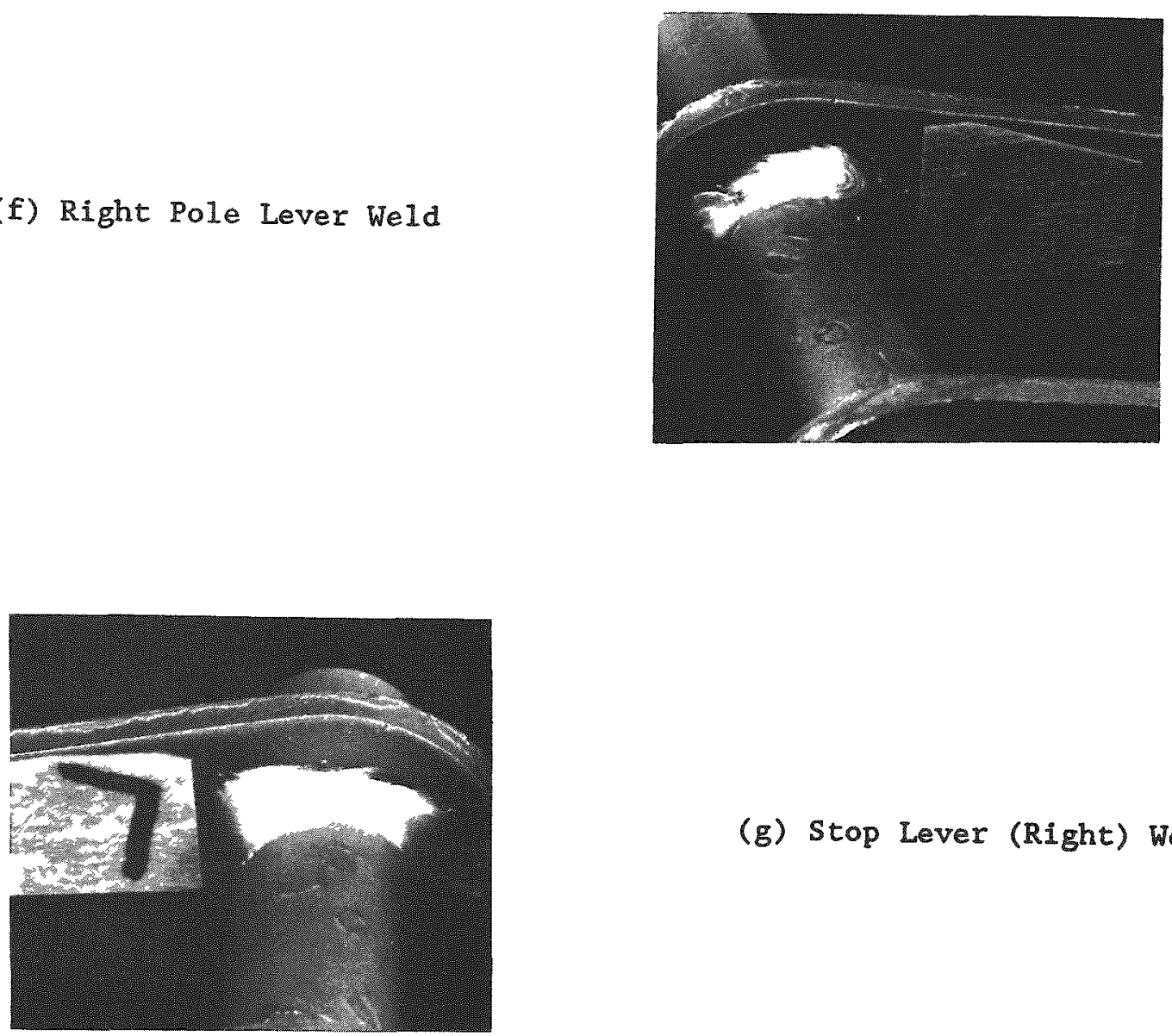

(g) Stop Lever (Right) Weld 
- NRC Bulletin - Because of the way both DS-circuit breaker models are constructed, the welds between the pole shaft and center lever cannot be visually or optically inspected effectively by simply removing the front panel.

\subsection{Feedback from Individual Utility}

Four utilities employing DS-series breakers in their plant class IE systems were contacted, and one site visit was made to discuss DS-breaker experience. During the visit we interviewed the electrical supervisor, the maintenance engineers familiar with the equipment, the quality assurance engineer, and the associated engineering groups responsible for short-term and long-term inspections of pole shaft welds per NRC Bulletin 88-01. This particular plant had not used any DS-breakers as RTBs; however, it utilized a large number of these breakers in class $1 E$ applications. Each of the two units contained 10 DS416 units and 40 DS-206 breakers. This section discusses this utility's perspectives on the failure of welds in the pole shaft (NRC Bulletin 88-01), and on the overall performance of the breakers.

\subsubsection{Pole-Shaft Welds}

This utility had inspected all pole shaft welds (both short-and longterm) simultaneously during a scheduled maintenance outage. Standard forms were completed for each pole shaft (i.e., each breaker) and which include all the criteria given in the bulletin, including the possible presence of porosity in the welds. If the shaft failed to meet the acceptance criteria, it was sent for rewelding, or was replaced by a new shaft.

This utility had experienced problems in weld failure in one of its breakers before the McGuire incident. An investigating team determined that the problem was due to substandard welding by the manufacturer. When the issue was presented to Westinghouse, the manufacturer categorized the event as an isolated case and took no further action, except to replace the shaft containing the broken welds. However, the utility continued to analyze the root cause of the failures, with metallurgical examinations of the shaft and the weld materials. Appropriate welding processes were developed for the low carbon steel shaft and the pole levers for Class $1 \mathrm{E}$ components. This later helped the utility to refurbish their defective pole shafts (i.e., those that did not pass the Bulletin inspection criteria) by performing a 360 degree weld of the shaft-lever assembly at the opposite sides to the original manufacturer's welds. Thus, the utility not only avoided long delays in procuring a new class $1 \mathrm{E}$ shaft, but also refurbished the breaker with a much stronger pole shaft at a fraction of the cost.

The inspection of welds by this utility showed that over $80 \%$ of the shafts did not qualify per the bulletin criteria: 
- sizes and shapes of the welds were not within the specifications

- starts of the welds were not fused properly to the lever arm-side

- a fillet leg mismatch

- lack of fusion on the shaft material

- evidence of porosity

- a few shafts had cracks in the welds.

The shafts that failed were rewelded at the backside of the lever before installing in the breaker assembly.

Based on the limited experience of this utility, we concluded that the number of breaker cycles on substandard welds caused the development of cracks. The motor breakers between the charging pump-motor breakers and faulty loading/unloading valves in the compressed air systems experienced almost 300 breaker cycles each year, including operating cycles, technical specification surveillance test cycles, and maintenance cycles. Breaker shafts in these breakers had cracks in their center pole lever welds. The life of these breakers with such a severe service condition was about 7-10 years.

\subsubsection{Other Breaker Problems}

As discussed earlier, the operation of a class IE breaker is quite different from that of a RTB. In case of RTBs, under normal condition, the breaker is in a charged condition, and on command from the control room, they trip to disconnect the power supply to the control rod drive motors. For class 1E operation, the breakers close the contacts to resume the electrical supply to the driving equipment. Since this plant has DS-breakers for the latter application, the failures experienced were related to the closing mechanisms of the breaker assembly. These breakers are subjected to more frequent operations (i.e., charging pump motors and air compressor motors) and failed more often than less frequently operating breakers. Thus, the experiences observed by this utility agreed with the vendor's experiences in non-nuclear applications. Mechanical stresses on various components of the breaker caused by the charging, closing, and tripping the operating mechanisms predominate in the aging of these breakers. As in the case of high-voltage breakers, this utility feels that breakers with more frequent operations should have a built-in counter to record the total number of cycles. This strategy would help to clarify the aging stresses caused by cycling.

We obtained the maintenance work requests (MWRs) for the four charging pumps at this plant; the data, summarized in Figure 5-2, covers 10 years in which there were 37 incidents. Closing coils and the closing spring release devices account for $62 \%$ of the total failures. It seems that under severe service conditions, this particular mechanism has a finite life and needs to be closely monitored for frequent replacement or service. In most cases, the coil was replaced; however, often the root cause of these failures was not identified. 


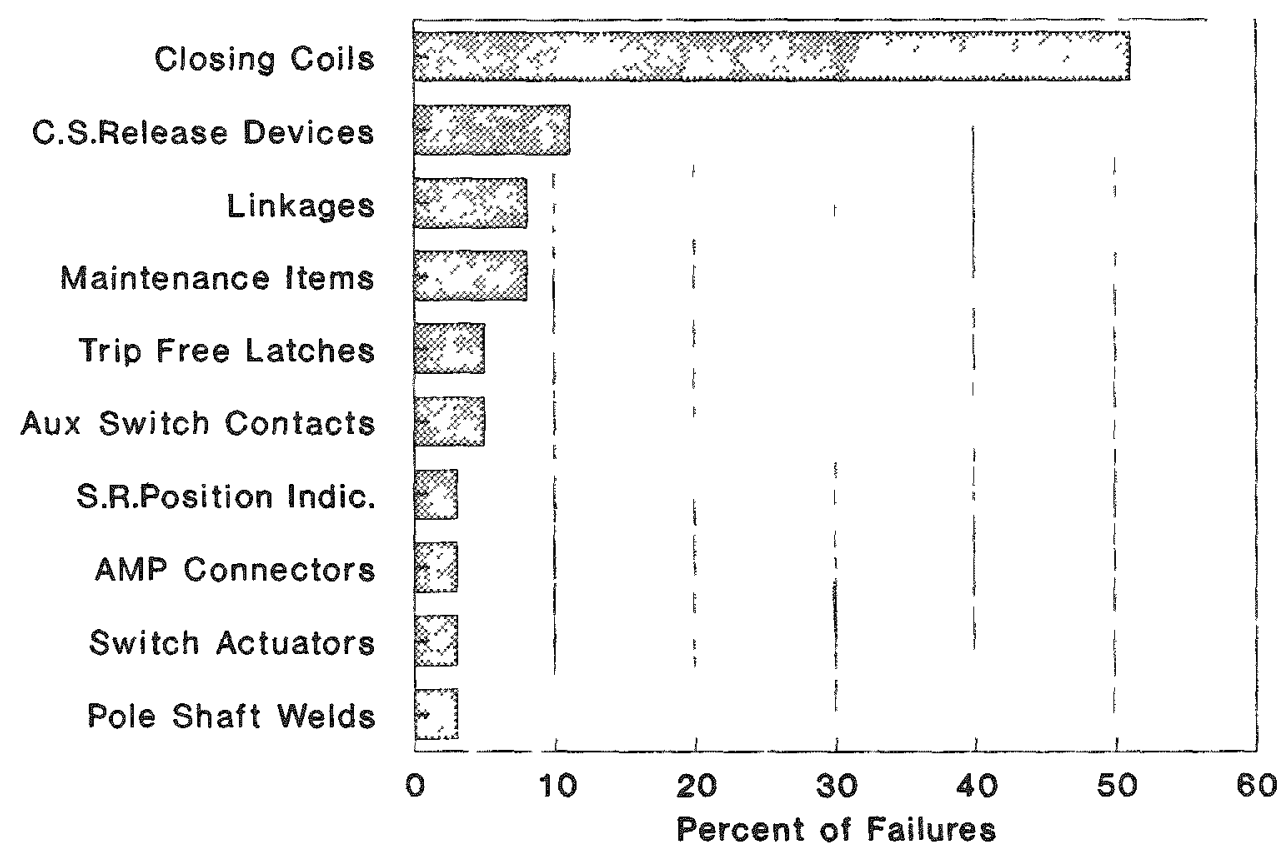

Figure 5.2 Maintenance History for Four Charging Pump-Motor Breakers (6/77-12/88) Total Number of Failures - 37

In addition to the experiences discussed in this section, the maintenance records provided supplemental information, including connection problems within AMP connectors, grooved surfaces, binding of the trip latch spring, and wear of ratcheting wheels. Improper crimping of the AMP connectors results in loosening of the connections under high vibration, e.g. closing/opening operations, and thus the STA and other control devices fail to receive the proper signal for breaker operation.

There are several places the trip latch mechanism rubs against some plates causing grooves on the plates. This abrasion eventually causes binding in the trip linkage. Also, the binding of trip-latch spring (the vertically mounted smal1 spring in the front) causes the trip free mechanism to trip while closing the breaker. Thus, the breaker would not close even if it was in charged position and ready to be closed. Using a sparse covering of graphite-based lube oil prevents the plate grooving, as well as preventing problems with the spring binding. 
Each time the breaker is charged, the ratcheting wheel is subjected to a high mechanical stress. Therefore, breakers that are more frequently cycled have excessive wear on the teeth of the ratcheting wheel. Excess lubrication on this wheel may be detrimental because of dirt buildup. Periodic evaluation of the condition of this wheel can prevent breaker failure. Also, wear has been a problem around the closing cam where the gaps around it become larger as the breaker experiences a large number of cycles. Hence, binding of the charging mechanisms causes excessive force on the pole shaft welds, and may cause the breaker to fail prematurely. This utility changes the entire operating mechanisms more frequently for breakers experiencing more than 200 cycles/year.

\section{$5.6 \quad$ Discussion}

In summarizing the results we note:

- The McGuire event, and the issuance of NRC Bulletin 88-01, could have been avoided if the root cause of the potential weld failure at other utilities had been investigated.

- The earlier reactor trip breaker events caused by sticking problems in the UVTA linkage have been rectified recently after implementing the periodic cleaning and lubricating of the UVTA parts and the four criteria set out in NRC generic letter 83-28 (following the Salem ATWS events).

- The problem of weld failure in the pole shaft-lever was attributed by the large number of breaker cycles (i.e., charging, closing, and tripping) causing high stress at the substandard welds.

- Several components within a breaker assembly age during operating faster than the overall breaker. A life of 1200 cycles or 8 years has been discussed within the NRC for replacement or refurbishment of reactor trip breakers. Based on the BNL test results, the 1 ife of an RTB is estimated to be 5000 cycles or 20 years. During this interval periodic inspection, surveillance, monitoring, and maintenance activities should be performed to maintain the operational readiness of these breakers. 
In addition to the statutory requirement for surveillance testing of breakers for operational readiness, the frequency of regular maintenance on air circuit breakers is influenced mainly by their application, environmental conditions, and frequency of operation under overload or short circuit conditions. The goals of maintenance should be (1) cleanliness, (2) good operating condition, and (3) mitigation of the aging effects. The type and frequency of maintenance depend, to some extent, on the cleanliness of the surroundings and the level of duty cycles. The maintenance program discussed here includes periodic inspection, monitoring, assessment of condition, as well as actual maintenance of the breaker assembly.

It is not our purpose to provide detailed procedures (i.e., step-by-step) for removing, testing, or installing the breakers while they are in the switchgear cabinets, nor on how to perform the maintenance on any component in the breaker assembly, as discussed in the maintenance manuals ${ }^{13}$. Although these items are essential for developing an effective maintenance program, our intent is to evaluate whether the current maintenance activities in the plant are appropriately managing the age-related degradation occur in breaker components.

\subsection{Breaker Maintenance Recommendations (Westinghouse) ${ }^{14}$}

Both DB-and DS-series air circuit breakers are designed to give continuous and reliable service. They are built to operate similarly to earlier vintage breakers (oil type circuit breakers), but with a minimun of maintenance. Their simplified construction permits maximum accessibility for inspection and adjustments. Since DS breakers superseded DB breakers in 1968 , nuclear power plants use both types for reactor trip, as well as for Class $1 \mathrm{E}$ and Non-Class $1 \mathrm{E}$ applications.

A thorough inspection is recommended six months after equipment is first placed in service, then each time a given number of operations has been recorded (at least once a year). If the annual inspection shows no maintenance is needed, the period may be extended to a longer time, and vice versa. The schedules for typical inspection and lubrication of breaker parts are 1750 operations for the DS-206 and 500 operations for the DS-416 model.

\subsubsection{General Practices}

The breaker should be pulled out of the compartment or drawer and the barriers and arc chutes removed. If there is a deposit of dust or dirt, low pressure dry air (from instrument air or handheld bellows) can be used to blow it clean, followed by vacuum cleaning. Accessible areas should be wiped with a clean dry cloth. If the breaker is dirty, and is hard to remove, i.e., oilbased dirt on the insulation, then a solvent approved by the manufacturer (inert or mild) should be used sparingly to remove the deposit. 
a) Structural Components - The structural elements of the switchgear and the breakers are typically built rugged and should not require any maintenance during the service life. However, switchgear experiencing many duty cycles can lose pin retainers, have loose nuts bolts or screws, and bent, worn, or damaged parts due to the vibration caused by the breaker's operation. Any corrections needed should be made. For seismic considerations, the fastening of the anchor bolts or welds of the switchgear cabinets to their supports should be inspected periodically.

b) Mechanical Components - These components include the operating mechanism, the contacts, and the arc chutes. Other auxiliary mechanical components, included in Section 2.1.2, such as barriers, drawout elements, position indicators, frames, and disconnecting contacts can be considered as structural elements, and should be treated similarly to the structural components.

Power Operated Mechanism - With increased duty cycles, the parts wear out or distort for a variety of reasons, such as excessive mechanical force, rubbing of metal elements, or loose fasteners. Adjustments and corrective actions should be performed, as described in the equipment instruction book. While making adjustments, all locknuts should be tightened to the prescribed settings. The same holds true for replacement parts.

Friction is another important aging mechanism for breakers. An infrequently operated breaker can become sluggish or actually inoperable under certain conditions. In a moisture-laden atmosphere, rust or corrosion on pivotal parts, latches, trip gears, actuators and other vital components can cause a breaker to "hang-up" when required to trip. Failure to lubricate regularly or the use of improper lubricants can cause sluggish operation. The manufacturers's recommendations for the type of lubrication and frequency should be followed. Under no circumstances should parts be over-lubricated.

Elements causing binding include mechanical interference caused by loose hardware, the presence of rust or corrosion on the close fitting pin or bearing surfaces, hardened lubricants or grease, and loose fasteners or worn out parts. Appropriate actions should be carried out, such as cleaning away the dirt with solvent and then relubricating the parts affected by friction.

Most breakers feature some type of "anti-bounce" device to cushion the opening stroke and prevent damage caused by metal-to-metal contact. These shock absorbers should be properly adjusted to prevent shocks being transmitted to all parts of the breaker. Shocks could loosen hardware, shear pins, and bend or distort components that can affect breaker operation. It is not good practice to overtighten accessible nuts, bolts or screws each time the breaker is inspected.

Contacts - Switching and fault interruptions, and arcing from motor "inrush" currents, cause pitting of the breaker contact parts. Depending on the number of operations, these contacts can become mottled, dirty, and eroded due to arc burning. We do not recommend filing or dressing these contacts or using any abrasive cloth/paper (emery cloth). 
The tolerances prescribed by the manufacturer should be maintained while replacing stationary, moving or arcing contacts. Most breaker contacts "close" with a controlled amount of rocking called "wipe". This wiping action polishes the contacts and keeps them in proper relationship as they wear. Contact spring pressure is very important, and the contacts may overheat if these springs break or weaken.

Overheated, badly pitted, or burned contacts have a discolored surface. Weak contact springs change the contact pressure which, in turn, changes the contact's resistance and heating will result. If there is misalignment of the contacts, they may overheat. Hence, periodic inspection of the assembly of the contacts, and measurements of their resistance are recommended.

To avoid prolonged arcing when the breaker is opened or closed, the arcing contacts are the first to touch on the closing cycle and the last to part on the opening cycle. The main contacts carry the load current. When the breaker opens, the main contacts separate first with little or no arcing because the load current is intentionally transferred to the arcing contacts. Therefore, the arcing contacts require more frequent maintenance or replacement.

Arc Chutes: $V$-shaped slots in the arc chutes gradually erode with the axc interruptions. This slow erosion is a normal result of electrical arcing; heavy fault interruptions can cause rapid erosion. When the steel "splitter" plates have about $1 / 4$ inch of their material eroded away at the top of the $V$-shaped slots they should be replaced. Badly burned insulating plates should be replaced regularly.

The throat of the arc chute enclosure becomes burned and coated with soot from arc interruptions. Damaged areas should be cleaned with sandpaper and the enclosure blown out with air before installing new plates. Depending on the severity of the arc interruption, the whole assembly may have to be replaced.

c) Electrical and Control Components - The Ampector trip unit tester consists of an external power supply, a current-measuring device, and a precision timer for field checking the operating of the unit. The complete procedure for testing and calibrating the trip unit with this tester is included in the test's instruction sheet. When the tester is used, the breaker should be either in the "TEST" or "DISCONNECTED" position.

Electrical checks are limited to the closing and trip coils, and the motor to charge the breaker. Meggering the motor insulation and other typical motor tests will assure the motor's reliability. The auxiliary trip devices include the UVTA, STA, closing coil, overcurrent trip switch, high load switch (solidstate), and electrical connections. These devices require minimum maintenance; nevertheless, if they fail to perform their function the breaker will not respond to the commands from the control room or the equipment. 
An evaluation of several techniques for testing breakers is underway at Wyle Laboratories under the auspices of the NPAR program. This effort includes electrical tests such as timing tests, Ion detection, contact/coil resistance, hipot tests, insulation resistance, and infrared thermal scanning or pyrometry. The usefulness of these testing techniques will be assessed for this type of breaker, once their applicability and the intrusiveness are established.

\section{1 .2 Specific Activities}

The inspection and maintenance recommendations discussed here are taken from the Westinghouse Bulletin (IB 33-790-1F) that is typically supplied with the breaker unit. Westinghouse believes that these breakers, specifically those supplied for class $1 \mathrm{E}$ application, are manufactured under a high degree of quality control, of the best available materials, and with a high degree of tooling for accuracy and interchangeability of parts. To assure the operability of these components, Westinghouse recommends that they are kept clean; therefore, frequency of maintenance depends on the cleanliness of the surroundings.

A general inspection and lubrication on these breakers after the first six month service, are recommended at each 1750 operations for DS-206, and 500 operations for DS-416 breakers. If these numbers are not reached, it is recommended that an inspection be done at least once a year. Also, the frequency of inspection can be altered in accord with the amount of dirt accumulated, mechanical binding of linkages, insulation or other electrical damage, and other con. ditions that can affect the breaker operation. In addition, if a breaker is taken out for service the breaker should be carefully inspected visually. The general inspection includes physical appearance, missing parts, loose nuts, bolts or screws, bent, worn, or damaged parts.

The Westinghouse recommended maintenance consist of an overall inspection for cleanliness, adjustments of the contact system, and removal and inspection of the arc chutes. The contact systems should be replaced when specific dimensions cannot be maintained or insufficient contact material remains. The arc chutes require replacement when excessive erosion and wear are identified. Cleaning and sanding (or replacement) of the insulating enclosure of the arc chute may also be required due to erosion and accumulation of soot. Lubrication, with a specified non-oil base lubricant, is required on various parts of the mechanism.

Inspection of Contact Assemblies

In addition to periodic house-cleaning of breakers discussed earlier, the contact system should be inspected after removing the insulating barriers and the three arc chutes. Figures $6-1$ and $6-2$ show the contact assemblies and their adjustments for DS-206 and DS-416 breakers. The two self-locking nuts on the threaded stud of the insulating link should be adjusted until the front faces of the stationary main-contact fingers are parallel to the center section of the main contact. Table 6.1 summarizes the minimum dimensions for adjusting the contacts, and the time to replace contacts. 
Table 6.1 Minimum Dimensions for Contact Adjustments

\begin{tabular}{|c|c|c|c|}
\hline Breaker & $\begin{array}{l}\text { Dimension } \\
\text { (see Fig.6-1 \&6-2) }\end{array}$ & $\begin{array}{l}\text { Minimum } \\
\text { (inch) }\end{array}$ & Remarks \\
\hline $\begin{array}{l}\text { DS - } 206 \\
\text { (Closed) } \\
\\
\\
\text { DS - } 206 \\
\text { (Open) }\end{array}$ & \begin{tabular}{l}
\multicolumn{1}{|c}{$\mathrm{A}$} \\
$\mathrm{X}$ \\
$\mathrm{B}$ \\
Moving or sta- \\
tionary main con- \\
tact tips \\
Gap between the \\
stationary arcing \\
contacts
\end{tabular} & $\begin{array}{c}0.02 \\
\geq Y \\
0.25 \quad(\text { dia.rod }) \\
.03 \\
.42 \pm .08\end{array}$ & $\begin{array}{l}\text { When unable to maintain } \\
\text { replace arcing contacts } \\
\text { (both moving \& stationary) } \\
\text { Examine main contacts } \\
\text { If }<.03^{\prime} \text { replace contacts }\end{array}$ \\
\hline $\begin{array}{l}\text { DS }-416 \\
\quad \text { (Closed) }\end{array}$ & \begin{tabular}{l}
\multicolumn{1}{c}{ A } \\
\multicolumn{1}{c}{ B } \\
Main contact tips \\
Where main contact \\
material remains \\
sufficient "Dim. B" \\
Dimension "B"
\end{tabular} & $\begin{array}{l}.02 \\
1 / 4(\text { dia. rod }) \\
1 / 32 \\
>3 / 16 \text { (dia.rod) } \\
\leq 3 / 16\end{array}$ & $\begin{array}{l}\text { When unable to maintain } \\
\text { replace arcing contacts } \\
\text { Examine main contacts } \\
\text { If }<1 / 32 \text { "replace contacts } \\
\text { Satisfactory } \\
\text { Replace main contact }\end{array}$ \\
\hline
\end{tabular}

\section{Inspection of Arc Chutes}

Figures 6-3, 6-4 and 6-5 illustrate the details of arc chute assembly. Switching operations erode these V-shaped slots and the appearance becomes pitted, mottled, and sooty. They should be replaced when the steel-splitter plates have about 1/4" of material eroded away at the top of the V-shaped slots. It is a good practice to replace the insulating plates at the same time. The throat of the insulating enclosure of the chute can be sanded with sandpaper, and the enclosure blown out with air or brushed out before installing new splitter plates. Depending on the severity of duty, the entire assembly can be replaced.

\section{Adjustments}

The DS breakers are designed with very few adjustable parts. All the factory adjustments and settings normally are expected to hold for the life of the breaker.

\section{(a) Trip Latch Overlap}

The angular position of the trip shaft latch surface is adjustable in relation to the trip latch surface by means of a screw (trip shaft adjusting screw) located in the top of the actuator frame. 


\section{(b)}

The open position stop can be adjusted by rotating the cylinders to obtain a clearance of approximately .005 inch between the cylinders and the stop levers.
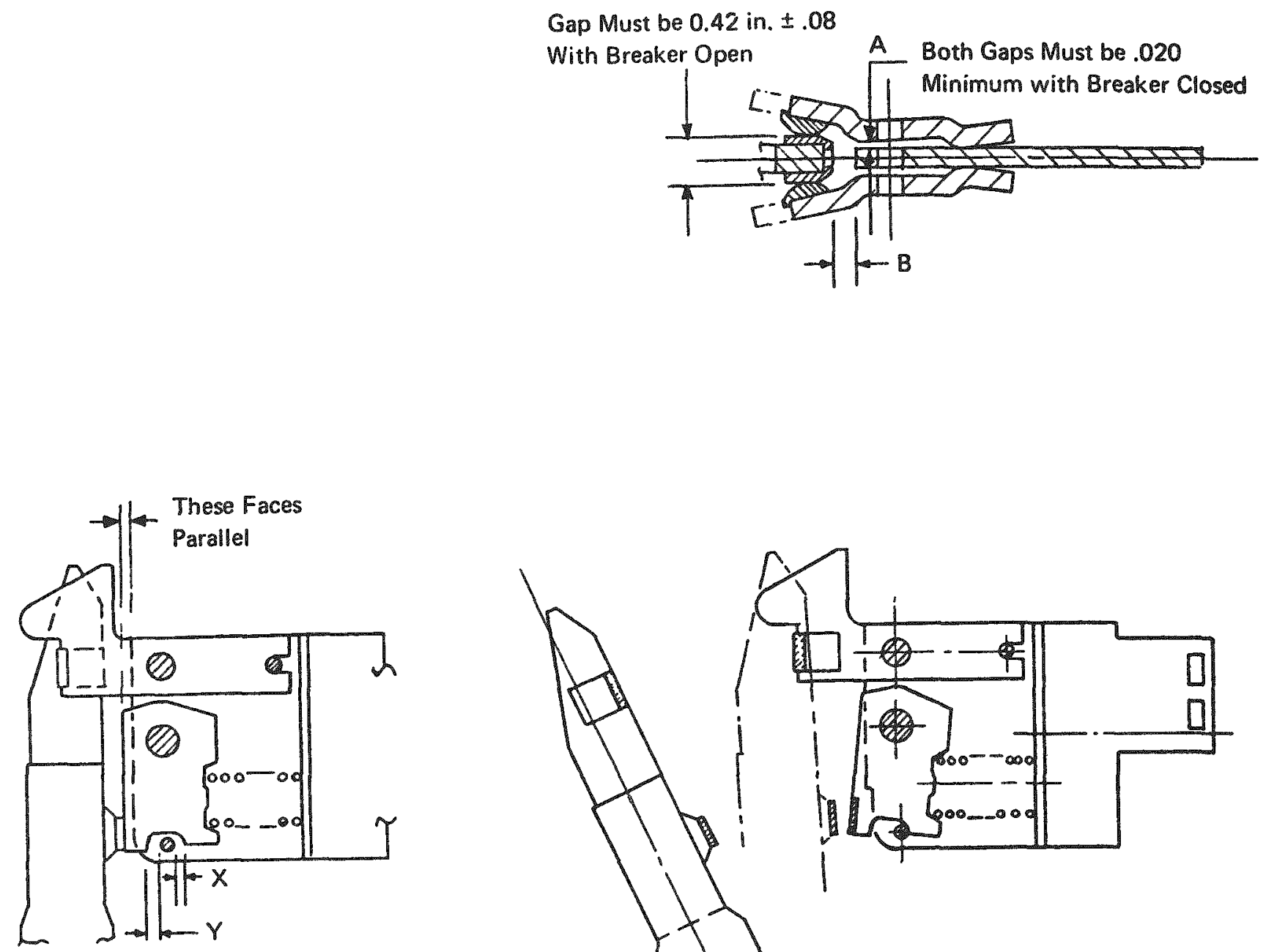

NOTE: Dimension "X" Must Equal or be Greater Than Dimension "Y"

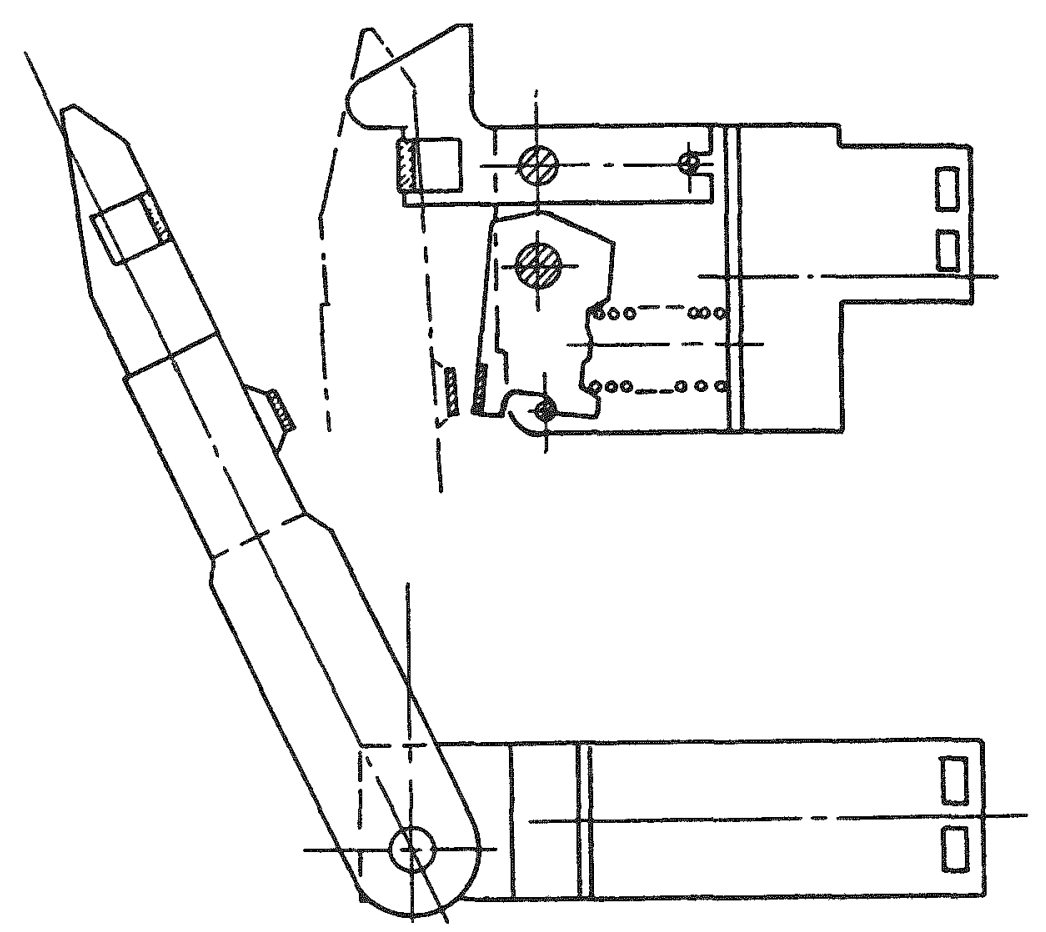

Figure 6-1 Contacts and Their Adjustment, DS-206 Breaker 

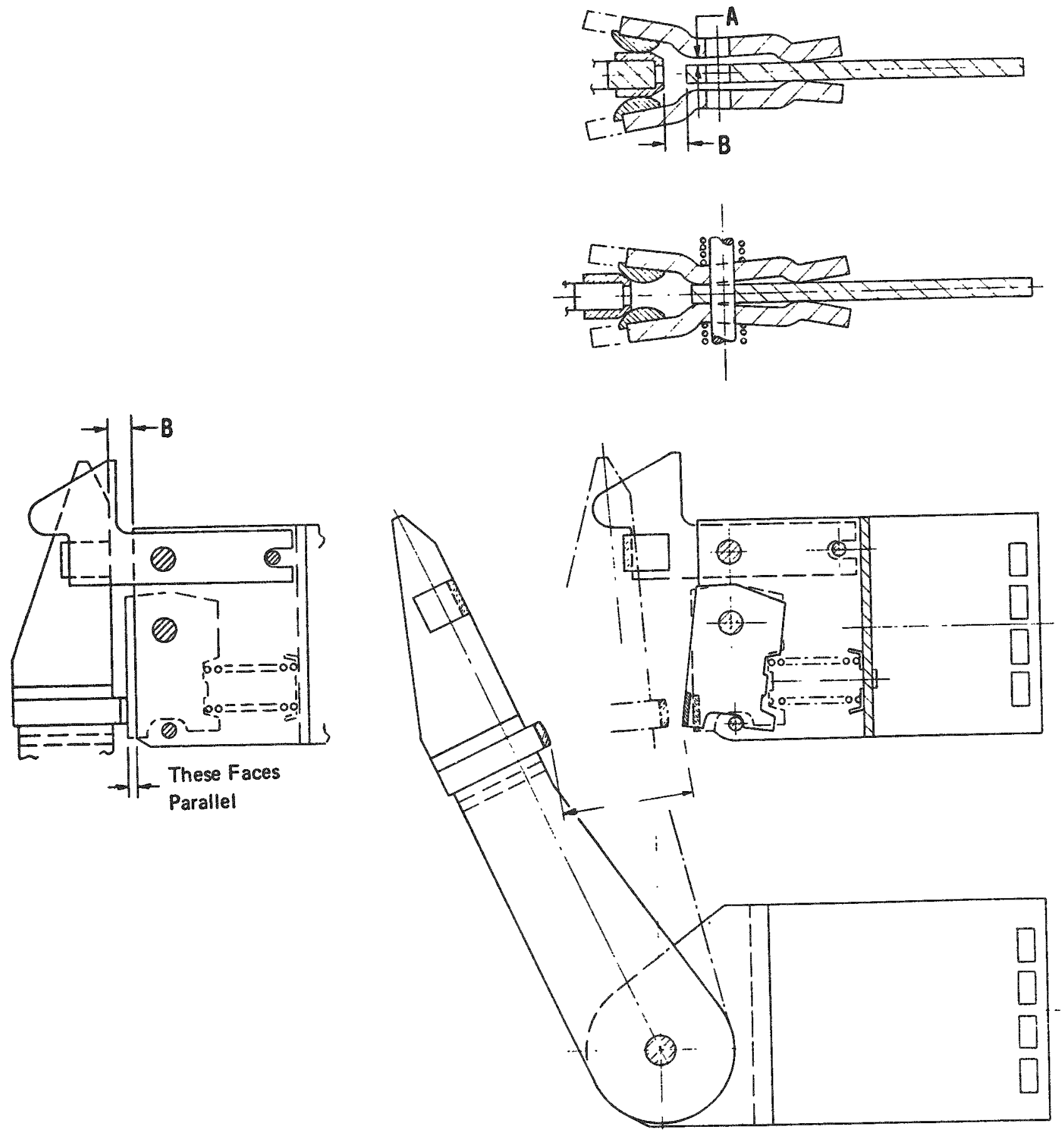

Figure 6-2 Contacts and Their Adjustments, DS-416 Breaker 


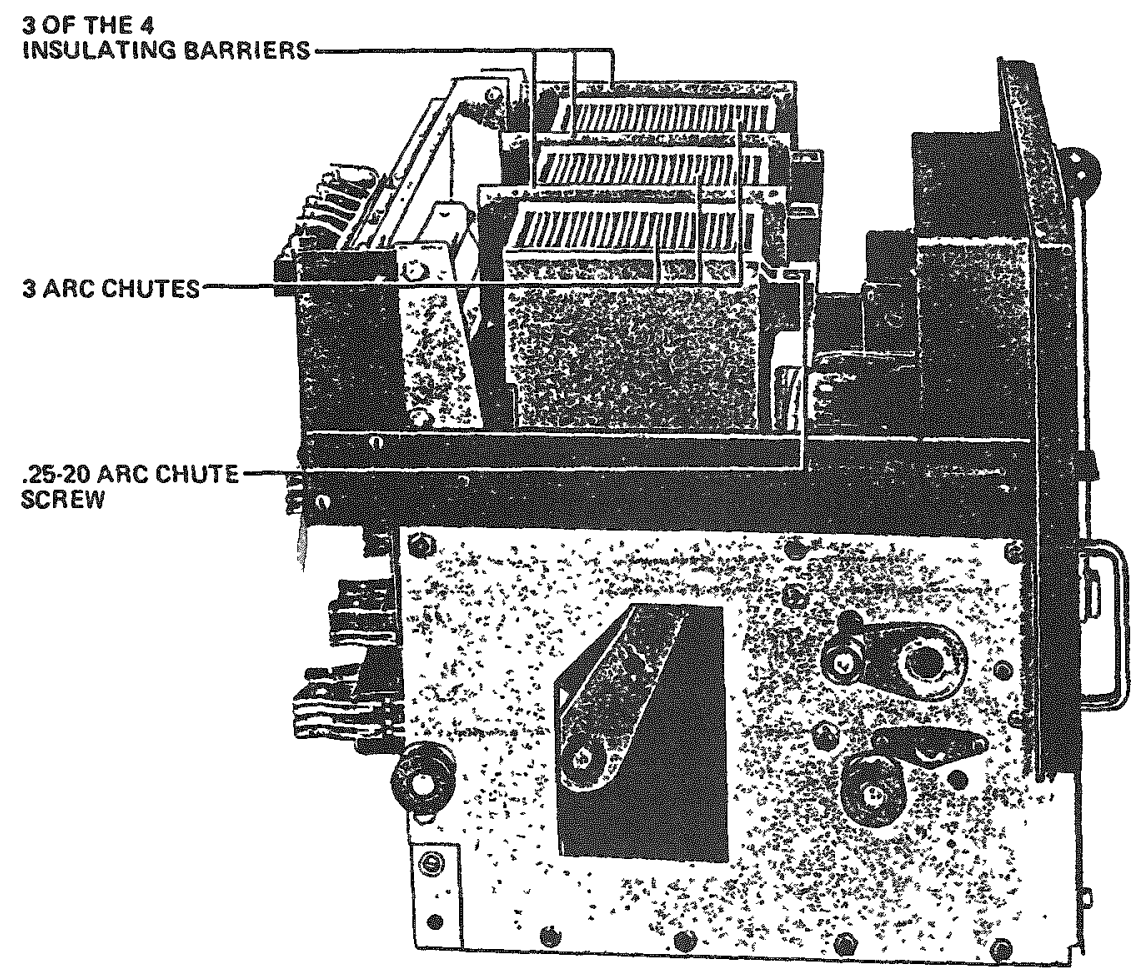

Figure 6-3 Breaker With Barrier Removed to Show Mounting of Arc Chutes

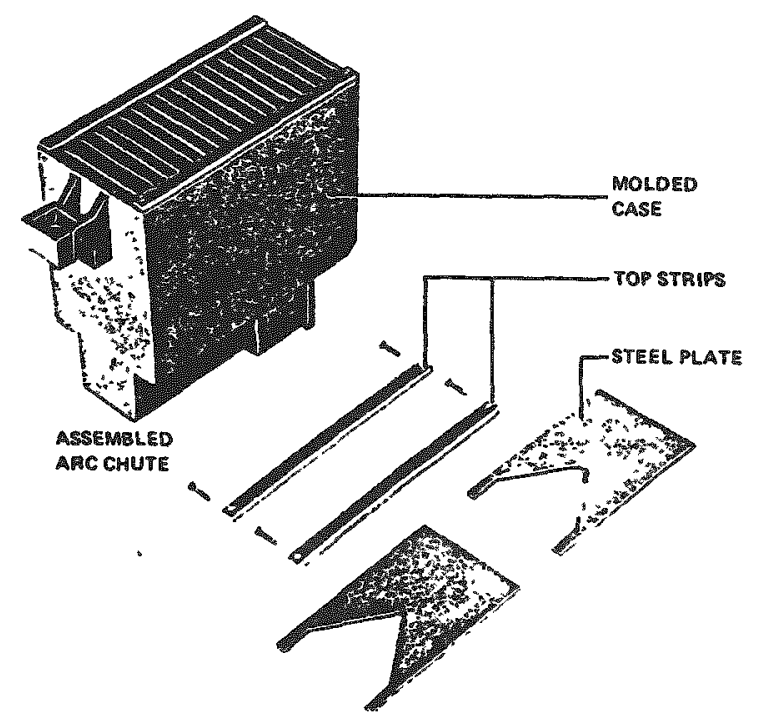

Figure 6-4 DS-206 Arc Chute

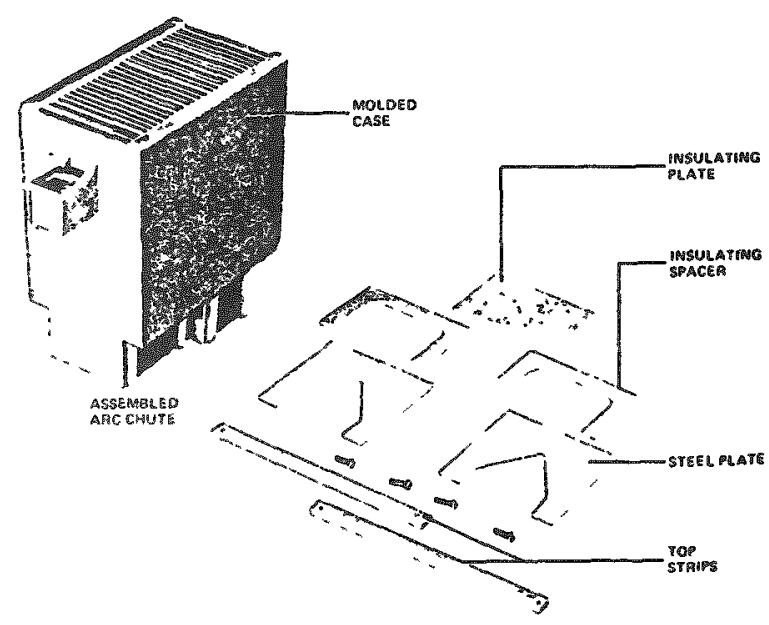

Figure 6-5 DS-416 Arc Chute 


\section{(c) Moving Contacts}

The contacts are engaged correctly when the vertical faces of the main fixed contacts and the fixed contact cage are parallel. For the DS-206, this is obtained by the adjusting nuts located on the insulating link stud above and below the pivot block. For the DS-416, this is achieved by rotating the insulating link after the lock nut has been loosened.

\section{Lubrication}

A Molybdenum lubricant should be used. All excess lubricant should be removed to avoid accumulation of dust or dirt, avoiding any lubricant on insulation or other electrical parts. Lubricants should be applied to the following points:

1. The spring-charge indicator bearing on the left side of the crank shaft.

2. The cam surface operating the cut-off switch link.

3. The pins on both ends of the constraining link.

4. The pins on both ends of the main drive link.

5. The curved surface of the trip latch.

6. Trip latch bearings - both side frames.

7. Both sides of oscillator plate where it pivots on the crank shaft.

8. The surface of the main close cam.

9. The trip shaft notch and both end bearings.

10. A molybdenum grease should be used at the main spring pins on each end of the crankshaft.

Note: All parts of the levering mechanism have sufficient lubrication, and should not require any further attention.

\subsection{Utility Maintenance Programs}

This section discusses typical preventive measures taken by the nuclear industry in maintaining the reliability of DS-breakers. These measures include preventive maintenance, periodic inspection, operability checks, and testing programs. 


\subsubsection{Technical Specification Requirements}

Under surveillance testing at nuclear power plants, each class $1 E$ breaker is required to remain OPERABLE or have OPERABILITY to perform its specific function(s). Therefore, all associated instrumentation, controls, normal and emergency power sources, cooling on seal integrity, lubrication or other auxiliary equipment that are required for the component to perform its function(s) must also be capable of performing their related support functions. To achieve this, the equipment is periodically subjected to either all or some of the following activities:

- channel calibration
- channel check
channel functional test

Channel Calibration - A channel calibration is the adjustment of the channel output so that it responds, with the necessary range and accuracy, to known values of the parameter which the channel monitors. The calibration encompasses the entire channel, including the sensor and alarm and/or trip functions, and includes the channel functional test.

Channel Check - This check is a qualitative observation of the channel's behavior during operation. This determination includes a comparison of the channel indication and/or status with other indications, and/or status derived from independent instrument channels measuring the same parameter.

Channe1 Functional Test - This test includes:

(a) Analog channels - the injection of a simulated signal into the channe1, as close to the sensor as practicable, to verify OPERABILITY including alarm and/or trip functions,

(b) Bistable channels - the injection of a simulated signal into the sensor to verify OPERABILITY including alarm and/or trip functions.

Reactor trip breakers at PWR plants are required to perform their channel functional tests in the power operation ( $>5 \%$ thermal power), startup modes ( $\leq 5 \%$ thermal power), and with the reactor trip system breakers closed and the control rod drive system capable of rod withdrawal. These tests should be performed at least once every 31 days with each train tested every other month and before each reactor startup if it was not tested in the previous 7 days.

Typically, there are two channels for reactor trip breakers and one is required to trip the system. However, operability should be established for both channels for all reactor modes discussed above. With the number of channels OPERABLE being one less than that required by the minimum channels OPERABLE, the reactor should be in HOT STANDBY within 6 hours; however, one channel may be bypassed for the next one hour for surveillance testing per technical specifications. 
For other Class 1E applications, the technical specification requirements for each breaker depend on the plant design and other safety considerations. However, the typical frequencies for breaker surveillance are:

Channel Calibration: At least once per 18 months.
Channel Check: At least once per 12 hours.
Channel Function Test: At least once per 31 days.

Although the surveillance activities discussed above are essential for monitoring the current health of the breaker for performing its intended function(s), the aging degradations occurring within the component cannot be entirely assessed without an effective maintenance program. A typical monthly functional testing of a RTB ranges from 5 to 15 breaker cycles, which is equivalent to the breaker being subjected to a yearly cycle of 60 to 180 . When these numbers are superimposed on the maintenance cycles they may exceed the design life of a DS-416 breaker in less than 10 years of plant 1ife.

\subsubsection{Preventive Maintenance}

The preventive maintenance program of utilities includes periodic inspection, lubrication, testing, and conditioning of the breaker components. A weekly walkdown around the breaker area is performed to assess qualitatively the condition of breaker cabinets. Any abnormal noise, collection of dust, or mechanical damages are inspected. In addition, each breaker is taken out of service for preventive maintenance every 18 months to 5 years, depending on the severity of duty, and the availability of the breaker without interrupting the plant's normal operation.

During this preventive maintenance (sometimes called calibration schedule) the breakers are subjected to the following services:

- Cleaning the breaker assembly, as discussed earlier.

- Lubricating parts with bearings and other linkage mechanisms.

- Calibrating or adjusting tolerances and contacts.

- Replacing or refurbishing worn parts.

- Testing the resistance on contacts

- Checking operability before installing back into the switchgear.

If a breaker is found failed and need corrective maintenance to bring it back to operation, after replacing the broken parts the breaker also undergoes the above servicing activities. This overall assessment or maintenance often requires about 15-40 breaker cycles before the breaker is brought back to service. Thus, a breaker with a prior history of failures accumulates a large number of maintenance cycles which later degrade the condition of other subcomponents, which may be detrimental to breaker life. 


\section{Typical lubricants used in DS-breaker application are:}

- Graphite grease, Westinghouse \#53701 ANOOT.

- MolyKote BR-2, Westinghouse $\$ 53701$ QB12J.

Any equivalent lubricants that are used should have the same characteristics as the manufacturer type. The application of lubricants should be done carefully, as discussed earlier. ing:

Other maintenance activities at nuclear power plants include the follow-

- Test of insulation resistance on the primary contacts at the disconnecting finger cluster using a $1000 \mathrm{~V}$ dc megger or equivalent

- Tests of primary contact resistance using a low resistance ohmmeter on the highest current output scale.

- Inspection of arc chutes for cleanliness and of the dimensions of erosion on the arc chute steel plates.

- Inspection of missing pins, pin retainers, loose nuts/bolts or screws, bent/broken or damaged parts including motor cutoff switch cam, and broken welds on the pole shaft.

- Inspection for excessive lateral play in the roller end of the main drive link where it contacts the close cam. The lateral play should be $1 / 8$ " or less (based on one utility's maintenance program).

- Checks of the clearance between the spring release coil armature and breaker frame by moving the armature side to side and forwards/. backwards to ensure there is no rubbing or binding.

- Inspection of the breaker's disconnecting finger clusters and secondary control contacts for wear and discoloration.

- With the breaker open, inspection of the contact tips of moving and stationary arcing and main contacts, and cleaning or replacement, as necessary.

- Adjustment of all contact dimensions discussed in Table 6.1.

- Checks of the auxiliary switch contacts using a multimeter for continuity, with the breaker in the open and close positions. If the contacts are dry, they should be brushed lightly with graphite grease.

- Checks of the charging motor brushes; the movement should be freed if necessary.

- Checks of the charging motor commutator and replacement, if needed. 
- Checks of the charging motor cutoff switch with a multimeter for continuity in the charged and discharged positions.

- Inspection of the breaker wiring for damage and proper routing.

- Performance of all post-maintenance operability tests.

\subsection{Life Testing of a DS -416 Breaker}

Additional information with regard to manufacturing, aging, and life assessment of various breaker parts was obtained from the life testing of a DS416 breaker performed at BNL. The breaker was subjected to over 36,000 mechanical cycles, and had experienced a number of problems in performing its function. The details of this test program are described in the Volume 2 of this NUREG. However, this section summarizes some of the findings that can be useful in formulating an effective maintenance program and can alleviate many of the aging problems. The summary below envelopes three areas, namely, manufacturing, aging, and life estimates of the breaker's power operated mechanism.

Manufacturing - Several deficiencies were found in the manufacturing and design of breaker parts procured recently from an electrical vendor. They include:

- Older pole shaft units (pre-McGuire event) contained substandard welds at the pole lever junctions.

- The machined surface of the pole pin A was found to have surface defects.

- Fracture of the trip bar wing suggested possible improper electroplating process.

- Newly purchased reset springs were found to have sharper bends at the neck of the hooks and caused stress concentration during operation leading to premature fractures.

- The material used for the newly obtained oscillators indicated $30 \%$ reduction in hardness than that of older units.

Aging - Most aging problems noted from the test program are caused by mechanical cycles alone. Burning of contact surfaces, erosion of arc chutes, and other arcing related problems are obvious attributes to aging when the breaker's power circuit is energized.

- Structural components and contact assembly parts indicate little aging due to mechanical cycles.

- A pole shaft with a bad weld $\left(60^{\circ}\right.$ weld size) could fail as low as 3000 cycles. First cracks were found in the \#1 and \#3 lever welds, which led to misalignment among the seven pole levers.

- Wear was evident in the following parts: 


$\begin{array}{ll}- & \text { Ratchet wheel } \\ - & \text { Holding pawls } \\ \text { - } & \text { Drive plate } \\ \text { - } & \text { Oscillator surface } \\ \text { - } & \text { Motor crank and handle } \\ \text { - } & \text { Closing cam segments } \\ \text { - } & \text { Roller constraining link } \\ \text { Deformation and/or distortion of parts include: } \\ \text { - Main drive link } \\ \text { - Main roller } \\ \text { - Mechanical reset springs } \\ \text { - X-Washers }\end{array}$

Life Estimates - Provided that the breaker is properly lubricated and periodic preventive measures are performed, the life of a Class $1 \mathrm{E}$ breaker can be estimated to be 5000 cycles or 20 years, whichever comes first. During this test period most components lasted over 10,000 cycles, except a pole shaft with $60^{\circ}$ weld at the \#3 lever which failed at 3000 cycles, and two indicator springs one of which failed at 5861 and the other at 2286 cycles. The conditions of parts identified in the aging section above after being subjected to over 10,000 cycles were severely damaged. Hence, the life cycle of a breaker of 5000 cycles is considered to be appropriate.

\subsection{Discussions}

Mitigating aging problems in DS-series breakers is discussed in this section. The information is based on recommendations provided by the manufacturer (i.e., Westinghouse) in various company publications, certain nuclear power plant maintenance manuals, and the BNL test program findings. It seems that the current plant activities are primarily based on good practices and experience. The statutory requirements (i.e., surveillance testing) do not address the maintenance of the component, instead they check the operability of the channel that contain these breakers. However, certain items which can be implemented to better manage aging in the breaker assembly are:

- On the part of the manufacturer, these breakers are built for the life of the plant, provided they are maintained in accordance with their recommendations. There are several components (in addition to contacts and arc chutes) within the breaker which have a finite life and need to be replaced at regular intervals. Some of the steps that should be made by the manufacturer to improve the breaker reliability include:

1) Improved exchange of technical information between the utilities and manufacturers. 
2) Improved dedication program to assure a commercially procured breaker suitable for safety applications.

3) Provide design data identifying the limit on the cycles for breaker components, such as closing coils, UVTA, STA, charging motor, ratchet wheel, and springs.

4) Improve design of components where necessary.

5) Inform utilities of the problems associated with breakers if there is a problem.

- The installation of cycle counters is recommended on all class 1E breakers.

- The engineering analysis of various breaker components discussed in Section 6.1, discussions of the utility maintenance programs in Section 6.2, and the laboratory test findings in Section 6.3, provide the basis for utilities to develop their own prescriptive maintenance programs that could alleviate all aging problems.

- Careful attention should be given for assessing the component design adequacy, when obtaining a new breaker or spare parts for the existing breakers.

- It is suggested that the maintenance program should include:

an overall condition inspection at each surveillance test interval,

- aging vulnerability check on parts susceptible to degradation at each $3-6$ months (or 50-100 cycle) period,

- an annual (or 250 cycles) maintenance schedule for complete checkup of all parts, lubrication at recommended locations, and replacement of degraded parts, and

complete overhaul or replacement (specifically, the power operated mechanism) after 20 years of service (or 5000 cycles). 
The primary focus of this study was to characterize the aging degradation in the Westinghouse DS-series circuit breakers and to recommend appropriate mitigating activities. Since the recent failure of the weld on the pole shaft in the McGuire RTB has promulgated this study, the results of the maintenance and upgrading of welds, including the utilities' responses to the NRC Bulletin 88-01, are also discussed in this section.

\subsection{Conclusions}

\subsubsection{Aging Assessment}

The designs of the Westinghouse DS-206 and DS-416 low voltage air circuit breakers are complex and use several mechanical and electrical devices. The operating mechanism that charges, closes, and trips the breaker, is the most complicated device and exhibits the most aging degradation, primarily because of the movements of various elements in this mechanism. The structural components are built with carbon steel structural materials and are the least susceptible to aging. Other mechanical parts, including the contacts and arc chutes experience high temperature burning and erosion due to the arcing of the auxillary contacts during the closing of the main breaker contacts. Finally, the electrical devices, including the electronic amptector unit which serves as the brain of the breaker, the coils in the trip devices and the charging motor, are typically subjected to electrical stresses which reduces their dielectric properties. Tripping and closing devices such as the UVTA, STA, and the closing coil are often built with mechanical linkages attached to them and are connected to the trip bar and other devices in the operating mechanism. Many of the operating problems in the breakers are due to the malfunction of these electromechanical devices. The burning of the coils in these devices is an effect of the binding in the linkages connected to them.

Based on our analysis of the operating data, the accelerated aging test at BNL, and the experience of utilities and breaker-service industry, the following are the aging characteristics of these DS-series breakers:

- Electrical control problems involving switch contacts, coil burnings, and trip device bindings, followed by problems associated with the operating mechanism dominate the breaker component failures.

- Most coil burnings result from sticky or binding of linkages somewhere in the power operation mechanism.

- Most problems were detected while closing and tripping the breakers.

- Foreign materials, such as dust or grease, dominate the causes of degradation of the breaker. Normal wear, overheating, and loss of adjustment are also responsible for a number of failures. 
- Normal operation of breakers causes wear of moving parts, including gear teeth, rubbing surfaces, binding of linkages due to drying of excess lubricants, burning of coils, friction between moving parts due to lack of proper lubrication, erosion of contacts, burning of arc chutes, and loss of adjustment of various components such as control devices, and alignment of poles.

- Earlier breaker problems relating to UVTA sticking seem to be mitigated by recommendations for lubricating the linkages provided by the Westinghouse technical bulletin and the NRC Generic Letter 8328.

- Breaker parts vulnerable to aging include:

- Ratchet Wheel

- Drive Plate

- Motor Crank and Handle

- Roller Constraining Link

- Main Roller

- X-Washers
- Holding Pawls

- Oscillator

- Closing Cam

- Main Drive Link

- Reset Springs

- Pole Pins

- Breakers experiencing a large number of cycles due to operation, surveillance, and/or maintenance exhibit the most problems.

\subsubsection{Failure in the Pole Shaft Weld}

The welding of levers to the pole shaft is performed as a commercial grade item, and there are inconsistencies in the size, shape, and appearance of the welds. This defect is primarily due to the lack of quality assurance on the products, and inadequacies in the Class $1 \mathrm{E}$ qualification program.

The operating experience in nuclear and non-nuclear facilities suggest that pole shaft failures associated with these DS-series breakers have not been an industry-wide problem. Shunt trip coil burning, charging motor malfunction, deterioration of power or control contact points, and failures of the trip latch mechanism far exceed the documented failures in the pole shaft welds. However, the root cause of these subcomponent failures was never analyzed. After the welds at the center pole shaft were found failed at the McGuire Nuclear Station, further laboratory and fracture surface testing revealed that the center pole shaft was misaligned on the closing cam. This problem allowed a high current to flow in the shunt coils for a longer than their rated value, which is typically for a very short time, and led to burnout of these coils. Similar conditions have caused premature failure of other control devices identified in the data bases of operating experience and the BNL test program.

The premature failure of the welds on the pole lever are due to the large number of trip cycles which imposes large fatigue stresses on the substandard weld-shaft material interfaces. Specifically, welds of the \#1 and \#3 levers are susceptible to develop cracks first, due to the fatigue loads imposed by the breaker operating cycles. Because of the improper welding procedures, cold work, porosity, or multiple weld passes on the core weld cleavage could be left 
where the cracks may develop after frequent cycling. After these cracks are developed, subsequent cycling could propagate to an early detachment of pole levers from the shaft. Once the weld has been separated, the main link on the closing cam could caused other mechanical problems, such as being stuck to corners, and wear of cam surfaces, which would prevent the breakers from tripping on demand. Thus, we conclude that too frequent cycling of the breakers causes fatigue at substandard welds, which is one of the root causes of breaker failure.

The short-term and long-term inspection programs recommended in the NRC Bulletin 88-01 contain improvements over the basic Westinghouse program. However, due to the important safety function performed by these circuit breakers, BNL considers that additional testing of these breakers was warranted. This testing was conducted (Volume 2), and has provided useful guidelines for the adequacy of the weld, as well as other important aging considerations.

Out of the 110 plants whose information on these inspections are available, 77 had no Class $1 E$ application of DS series circuit breakers; the 33 plants that suggested a large percentage of breakers failed the short-term criteria. Thus, we conclude that welds on the pole shaft of DS series breakers, manufactured prior to 1988 , are substandard.

It is important that guidelines for early detection of cracks in the pole welds be developed to avoid any breaker failures, particularly in the reactor protection and other systems important to safety. Cycle limits based on the condition of the weld should be established and appropriate maintenance and monitoring methods should be developed to detect cracks early. Based on limited experience, it seems that if the breakers are inspected according to NRC Bulletin 88-01 their refurbishment with new better-manufactured shafts, or with backside welds will eliminate any future events.

\subsubsection{Programs for Mitigating Aging}

Both the manufacturer and the utilities are aware of the aging problems in breakers, and how to mitigate them. However, lack of proper communication between them has resulted in many failures. A stronger coordination would alleviate many of the aging degradations discussed in the previous sections.

Most of the existing plant maintenance programs are based on the individual utility's experience and on good industrial practices. This NUREG report contains several salient points that can help to develop a good maintenance program to alleviate most aging degradations. The Maintenance Program Manual $1^{13}$ developed by the Westinghouse Owner's Group for the RTBs contains an extensive program. Each utility should consider these recommendations and those presented in this report to develop an effective maintenance program suitable for their applications. 


\subsection{Recomnendations}

Recommendations presented here are based on the design and operation reviews of the subject breakers, operating experience analysis, utility responses to NRC Bulletin 88-01 on pole shaft weld inspections, industry maintenance practices, and manufacturer's, as well as owner's group recommendations on good maintenance. In addition, results of the BNL life testing of a DS-416 breaker, as described in Volume 2 of this NUREG, are considered in detemining the 1ife estimates and other pertinent information relating to the breaker reliability. The following discussion provides information and recommendations related to three separate issues, namely: NRC Generic Letter 83-28 relating to RTB reliability after the Salem ATWS events in 1983, NRC Bulletin 88-01 relating to the pole shaft weld failures after the McGuire event in 1987, and defining elements of a good maintenance program to improve the breaker reliability.

\subsubsection{NRC Generic Letter 83-28 on RTBs}

The four areas covered by this letter are:

1) Post Trip Review

2) Equipment Qualification and Vendor Interface

3) Post-Maintenance Testing

4) Improvements in Reactor Trip System Reliability Relating to:

- Vendor-related modifications

- Preventive maintenance and surveillance program for RTBs

- Automatic actuation of STA for Westinghouse and B\&W plants.

This letter was issued after the Salem ATWS events caused by the RTBs failure to scram the reactor. The problems associated with these breakers included sticking of linkages in the UVTA, broken latch pin, binding of linkages, contaminations and drifting of set points in the tripping mechanism. Most of them resulted in a failure or malfunction of the UVTA which is responsible for not tripping the breaker in order to scram the reactor.

The primary purpose of this generic letter is to address issues that are related to reactor trip system reliability and general management capability in a plant. Problems associated with the reactor txip breakers (or scram breakers) are one of the essential elements that should be mitigated to assure the overall system reliability. The results from this study including the life testing of a Westinghouse DS-416 breaker provide a sound basis for developing procedures and criteria in the areas of equipment life estimates, vendor interface, main. tenance activities and monitoring techniques. Recommendations relating to the Westinghouse DS-416 RTBs are given as follows: 
- Earlier problems associated with reactor trip breakers, specifically those manufactured by Westinghouse were caused by sticking problems in the UVTA 1inkages. After the Salem ATWS events in 1983, improvements in the design, as well as in the maintenance activities had virtually eliminated this problem. The operating experience in recent years (post-1983) has indicated small problems relating to the UVTA linkage bindings. Hence, no additional plant activity is required.

- In addition to normal aging of the contact assembly, in recent years wear and fatigue of certain parts of the breaker operating mechanism in a DS-416 breaker dominated the problems. Inspection, surveillance, monitoring, and maintenance practices included in this report and the recommended schedule interval discussed should alleviate many of these aging problems.

- Based on the BNL test results, the expected life of a DS-416 breaker is 5000 breaker cycles or 20 years of operating life. Because of the repeatability of the aging characteristics in the operating mechanisms, life testing of a breaker in equipment qualification is not warranted. Rather prototype testing, such as this testing should be performed in each breaker type used in RTB application.

- Recently procured parts of the DS-416 breaker are found to exhibit faster aging degradation than those of the original breaker. In some cases, this has affected the life of the test breaker to a value as low as 2000 cycles.

- Prescriptive maintenance practices given in the Westinghouse Owners Group Maintenance Manual (MPM-WOGRTSDS 416-01, Rev. 0, Nov. 30, 1986) are recommended for improving the breaker reliability.

\subsubsection{NRC Bulletin 88-01 on Pole Shaft Welds}

Prior to the McGuire reactor trip breaker event in 1987, a number of problems associated with various parts of the operating mechanism in a DS-416 breaker was identified by the NRC. Bulletin 88-01 was issued after it was found that the failure to scram the reactor at McGuire was due to the cracking of pole lever welds on the pole shaft. Utilities were asked to inspect all their class $1 E$ breaker pole shaft welds according to the criteria described in the bulletin. If the quality of any weld failed to satisfy the criteria, the pole shaft was required to be replaced or repaired to rectify the weld problem. Based on the results of the utility responses, and the BNL tests the following recommendations are suggested:

- Pole shafts with substandard welds should be replaced or repaired to avoid any problems that could result from the weld failures of the pole levers. 
- Based on the 1ife testing, \#3 lever weld experiences the worst stress condition under normal operation. Cracks in the \#1 and \#3 welds start first and cause the breaker inoperable when they are allowed to grow to sizes of $25 \%$ of the weld length. Monitoring of these two welds should be performed to avoid any problems stemming from the weld cracks.

\subsubsection{Improving Breaker Reliability}

The operating experience review of breakers in nuclear power plants, and the life testing at BNL provide the following recommendations which should augment the current maintenance practices detailed in the Owner's Group Maintenance Manual ${ }^{13}$ :

A cycle counter should be installed on each Class $1 \mathrm{E}$ breaker to register the actual cycles experienced,

- While procuring a new breaker, or spare parts for an existing one, attention should be given to assess their design adequacy, i.e., changes in physical dimensions or shapes, materials.

- The 1ife of a DS-416 or DS-206 (as opposed to that recommended by the manufacturer) should be either 5000 cycles or 20 years, whichever comes first.

- At each surveillance testing interval (if possible) and/or at each 3-6 month period (or 50-100 cycles), the breaker parts vulnerable to aging should be inspected and if required, should be refurbished.

- An annual (250 cycles) maintenance schedule should include a complete checkup of all parts, lubrication at recommended locations, cleaning, and replacement of degraded component. 


\section{REFERENCES}

1. Toman, G.J., ot a1., "An Aging Assessment of Relays and Cixcuit Breakers and System Interactions," NUREG/CR-4175, June 1987.

2. USNRC Memorandum to Kahtan N. Jabbour from Darl S. Hood, "Summary of September 23, 1987 Meeting on Westinghouse Switchgear Failures (TACS 65955/65956)," October 2, 1987.

3. Toman, G.J., et al., "Investigation of Trip Breaker Failure at McGuire Unit 2," Franklin Research Center Report F-6177-5, June 15, 1988.

4. Letter from T. E. Murley, NRC to C.L. Caso, Westinghouse on "Failures of Westinghouse Circuit Breakers Indicate Lack of Quality Control, "November $22,1988$.

5. "Instructions for Type DS Low Voltage Metal-Enclosed Switchgear," Westinghouse Electric Corp., December 1969.

6. "Instructions for Low-Voltage Power Circuit Breaker Types DS-206, DS-416 and DS-532, Westinghouse Electric Corp., May 1971.

7. "Low Voltage Power Circuit Breakers Types DS and DSL," Westinghouse Electric Corp., July 1981.

8. Instructions and Maintenance Manual - Reactor Trip Switchgears, Westinghouse Electric Corp., 1986.

9. Memorandum from D.A. Wright to J.P. McVicker, "CCNPP 480 Volt Breaker No. 52-1108-NRC 3894," Calvert Cliff Nuclear Power Plant, September 18, 1986.

10. Memorandum from G.L. Plumlee, III to R. L. Dennig of AEOD on "Westinghouse DS-416 Trip Breaker - NPRDS Evaluation of Operational Experience," July $10,1987$.

11. Verna, B.J., "Reactor Trip System Breaker Problems," Part 1, November 1983, Part 2, January 1984, and Part 3, March 1984, Nuclear News.

12. Westinghouse Presentation to NRC on Circuit Breaker Problems on January 12, 1989.

13. Conner, L.T., and Steinel, G.C., "Maintenance Program Manual (MPMWOGRTSDS416-01) for Westinghouse Type DS-416 Reactor Trip Circuit Breakers and Associated Switchgear," Westinghouse Owner's Group, Rev, 0, November $30,1986$. 
14. Westinghouse Electrical Maintenance Hints, Westinghouse Electric Corp., Printing Division, Trafford, PA 15085.

15. Subudhi, M., MacDougal1, E., Kochis, S., Wilhelm, W., and Lee, B.S., "AgeRelated Degradation of Westinghouse 480 Volt Circuit Breakers: Mechanical. Cycling of a DS-416 Breaker-Test Results," Volume 2, NUREG/CR-5280, Draft. Available from the NRC Public Document Room, Accession Number 9007020091. 
NRC Information Notices. Bulletins, and Generic Letters on Circuit Breakers

Related Problems in Nuclear Power Plants

1) IE Bulletin No. 78-05, "Malfunction of a Circuit Breaker Auxiliary Contact Mechanism - General Electric Model CR105X," U.S. Nuclear Regulatory Commission, Office of Inspection and Enforcement, Washington, DC, April $14,1978$.

2) IE Bulletin No. 79-09, "Failures of GE Type AK-2 Circuit Breakers in Safety-Related Systems," U.S. Nuclear Regulatory Commission, office of Inspection and Enforcement, Washington, DC Apri1 17, 1979.

3) U.S. Nuclear Regulatory Comission, Cixcular 81-12, "Inadequate Periodic Test Procedure of PWR Protection System," July 22, 1981.

4) IE Bulletin No. 83-01, "Failure of Reactor Trip Breakers to Open on Automtic Trip Signals," U.S. Nuclear Regulatory Commission, Office of Inspection and Enforcement, Washington, DC February 25, 1983.

5) IE Bulletin No. 83-04, "Failure of the Undervoltage Trip Function of Reactor Trip Breakers," U.S. Nuclear Regulatory Commission, Office of Inspection and Enforcement, Washington, DC March 11, 1983.

6) IE Bulletin No. 83-08, "Electxical Circuit Breakers with an Undervoltage Trip Feature in Use in Safety-related Applications other than the Reactor Trip System," U.S. Nuclear Regulatory Commission, Office of Inspection and Enforcement, Washington, DC, December 28, 1985.

7) IE Information Notice No. 83-18, "Failures of the Undervoltage Trip Function of Reactor Trip System Breaker," U.S. Nuclear Regulatory Commission, Office of Inspection and Enforcement, Washington, DC, April $1,1983$.

8) NRC Generic Letter 83-28, "Required Actions Based on Generic Implications of Salem ATWS Events," U.S. Nuclear Regulatory Commission, Office of Inspection and Enforcement, Washington, DC, July 8, 1983.

9) IE Information Notice No. 83-50, "Failure of Class 1E Safety-Related Switchgear Circuit Breakers to Close on Demand," U.S. Nuclear Regulatory Commission, Office of Inspection and Enforcement, Washington, DC. August $1,1983$.

10) IE Information Notice No. 83-76, "Reactor Trip Breaker Malfunctions (Undervoltage Trip Devices on GE Type AK-2-25 Breakers)," U.S. Nuclear Regulatory Commission, Office of Inspection and Enforcement, Washington, DC, November 2, 1983. 
11) IE Bulletin No. 85-02, "Undervoltage Trip Attachments of Westinghouse DB-50 Type Reactor Trip Breakers," U.S. Nuclear Regulatory Commission, office of Inspection and Enforcement, Washington, DC, November 5, 1985.

12) IE Information Notice No. 85-58, "Failure of a General Electric Type AK2-25 Reactor Trip Breaker,: U.S. Nuclear Regulatory Commission, office of Inspection and Enforcement, Washington, DC, July 17, 1985, Supplement 1, November 19, 1985.

13) IE Information Notice No. 85-82, "Diesel Generator Differential Protection Relay Not Seismically Qualified," U.S. Nuclear Regulatory Commission, Office of Inspection and Enforcement, Washington, DC, October 18, 1985.

14) IE Information Notice No. 85-93, "Westinghouse DS Circuit Breakers, Potential Failure of Electric Closing Feature Because of Broken Spring Release Latch Lever," U.S. Nuclear Regulatory Commission, Office of Inspection and Enforcement, Washington, DC, December 6, 1985.

15) IE Information Notice No. 86-62, "Potential Problems in Westinghouse Molded Case Circuit Breakers Equipped with a Shunt Trip," U.S. Nuclear Regulatory Commission, Office of Inspection and Enforcement, Washington, DC, July 31, 1986.

16) IE Information Notice No. 87-12, "Potential Problems with Metal Clad Circuit Breakers, General Electric Type AKF-2-25," U.S. Nuclear Regulatory Commission, Office of Inspection and Enforcement, Washington, DC, February 13, 1987.

17) NRC Information Notice No. 87-35, "Reactor Trip Breaker, Westinghouse Model DS-416, Failed to Open on Manual Initiation from the Control Room," U.S. Nuclear Regulatory Commission, Office of Nuclear Reactor Regulation, Washington, DC, July 30, 1987, Supplement 1, December 16, 1987.

18) NRC Information Notice No. 87-41, "Failure of Certain Brown Boveri Electric Circuit Breakers," U.S. Nuclear Regulatory Commission, Office of Nuclear Reactor Regulation, Washington, DC, August 31, 1987.

19) NRC Information Notice No. 87-61, "Failure of Westinghouse W-2 Type Circuit Breaker Cell Switches," U.S. Nuclear Regulatory Commission, office of Nuclear Reactor Regulation, Washington, DC, December 7, 1987, Supplement 1. May 31, 1988.

20) NRC Bulletin 88-01, "Defects in Westinghouse Circuit Breakers," U.S. Nuclear Regulatory Commission, office of Nuclear Reactor Regulation, Washington, DC, February 5, 1988.

21) NRC Information Notice No. 88-38, "Failure of Undervoltage Trip Attachment on General Electric Circuit Breakers," U.S. Nuclear Regulatory Commission, office of Nuclear Reactor Regulation, Washington, DC, June 15, 1988. 
22) NRC Information Notice No. 88-42, "Circuit Breaker failures due to Loose Charging Spring Motor Mounting Bolts, "U.S. Nuclear Regulatory Commission, office of Nuclear Reactor Regulation, Washington, DC, June 23, 1988.

23) NRC Information Notice No, 88-44, "Mechanical Binding of Spring Release Device in Westinghouse Type DS-416 Circuit Breakers," U.S. Nuclear Regulatory Commission, Office of Nuclear Reactor Regulation, Washington, DC, June 24, 1988.

24) NRC Information Notice No. 88-45, "Problems in Protective Relay and Circuit Breaker Coordination," U.S. Nuclear Regulatory Commission, Office of Nuclear Reactor Regulation, Washington, DC, July 7, 1988.

25) NRC Information Notice No. 88-46, "Licensee Report of Defective Refurbished Circuit Breakers," U.S. Nuclear Regulatory Commission, Office of Nuclear Reactor Regulation, Washington, DC, July 8, 1988, Supplement 1, July 21, 1988. 